\title{
The Caddo Archaeology of the Musgano Site (41RK19) in the Sabine River Basin of East Texas
}

Timothy K. Perttula

Heritage Research Center, Stephen F. Austin State University

Follow this and additional works at: https://scholarworks.sfasu.edu/ita

Part of the American Material Culture Commons, Archaeological Anthropology Commons, Environmental Studies Commons, Other American Studies Commons, Other Arts and Humanities Commons, Other History of Art, Architecture, and Archaeology Commons, and the United States History Commons

Tell us how this article helped you.

This Article is brought to you for free and open access by the Center for Regional Heritage Research at SFA ScholarWorks. It has been accepted for inclusion in Index of Texas Archaeology: Open Access Gray Literature from the Lone Star State by an authorized editor of SFA ScholarWorks. For more information, please contact cdsscholarworks@sfasu.edu. 
The Caddo Archaeology of the Musgano Site (41RK19) in the Sabine River Basin of East Texas

\section{Creative Commons License}

(c) (1) (2)

This work is licensed under a Creative Commons Attribution-NonCommercial 4.0 International License 


\title{
The Caddo Archaeology of the Musgano Site (41RK19) in the Sabine River Basin of East Texas
}

\author{
Timothy K. Perttula
}

with contributions by Leslie L. Bush, LeeAnna Schniebs, and Robert Z. Selden, Jr.

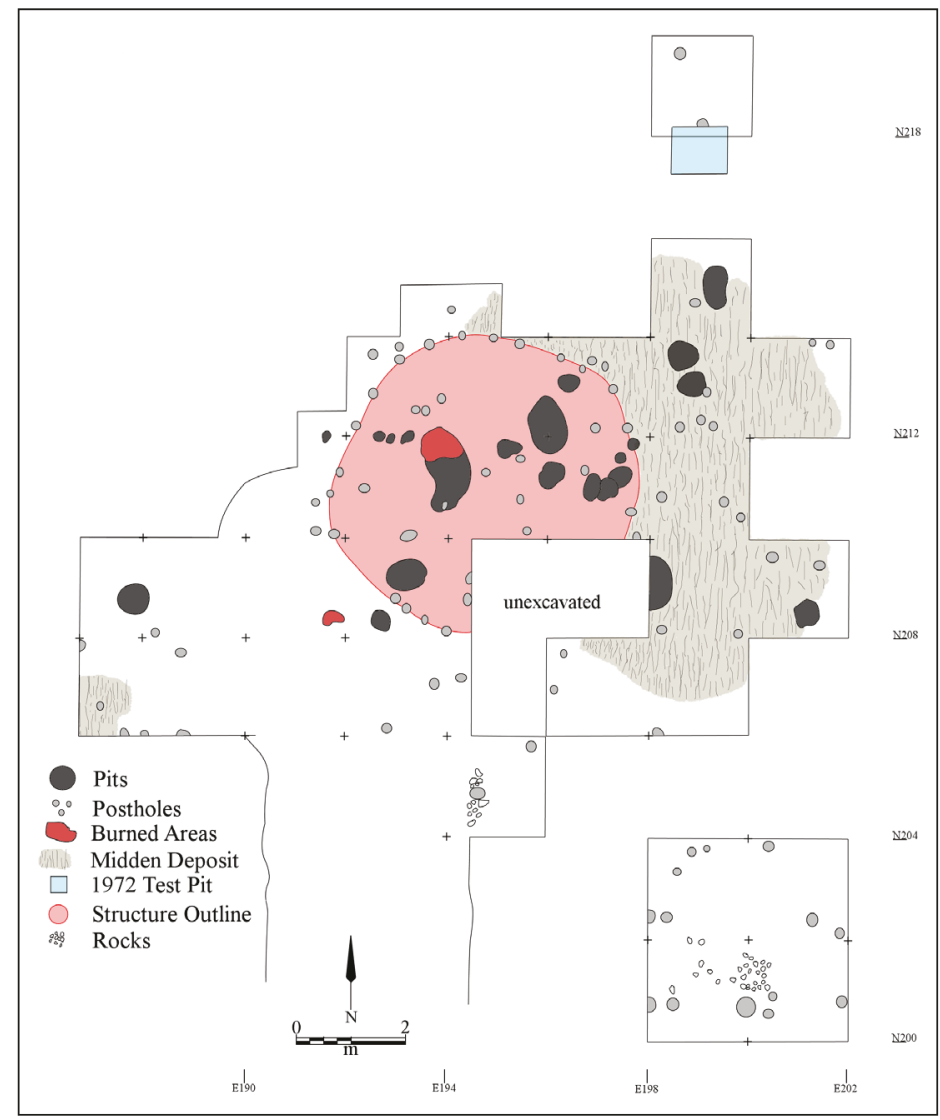

Special Publication No. 28

Friends of Northeast Texas Archaeology, Pittsburg and Austin 
Distribution, Bo Nelson, 344 CR 4154

Pittsburg, Texas 75686

RBoNelson@aol.com

Cover art:

1973 Block excavations at the Musgano site

Copyright (C) 2014, Friends of Northeast Texas Archaeology

(Austin and Pittsburg) 


\section{Table of Contents}

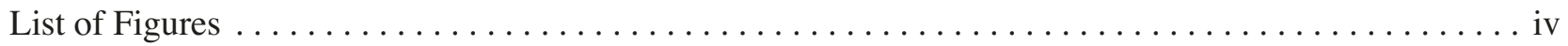

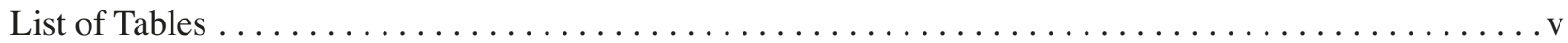

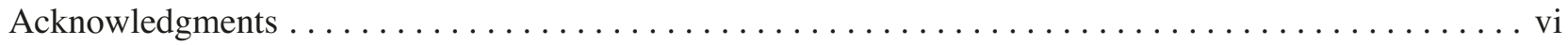

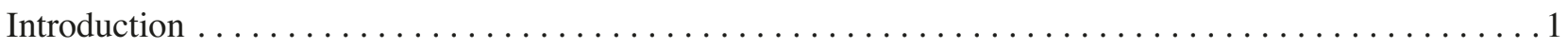

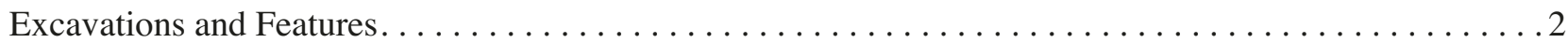

Age of the Archaeological Deposits, by Timothy K. Perttula and Robert Z. Selden, Jr . ..........5

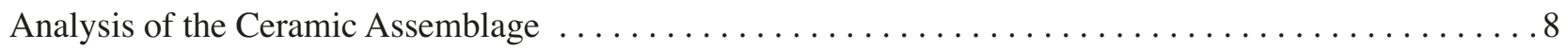

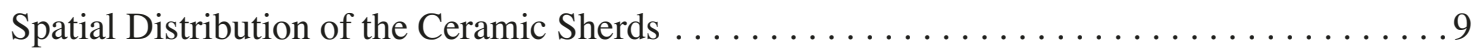

Plain Ware Rim Sherds. . . . . . . . . . . . . . . . . . . . . . . . . . . . . . 9

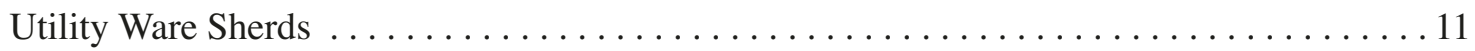

Fine Ware Sherds . . . . . . . . . . . . . . . . . . . . . . . . . . 23

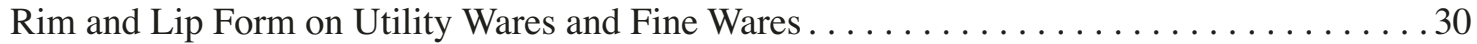

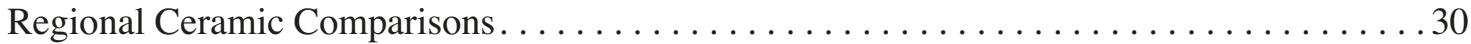

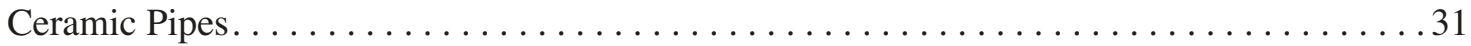

Chipped Stone Lithic Artifacts. . . . . . . . . . . . . . . . . . 34

Analysis of the Paleobotanical Remains from the Musgano Site, by Leslie Bush . . . . . . . . . . . 35

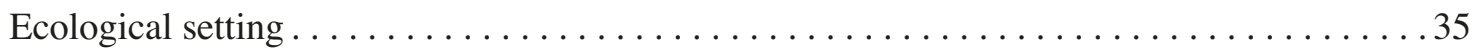

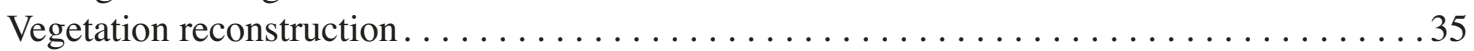

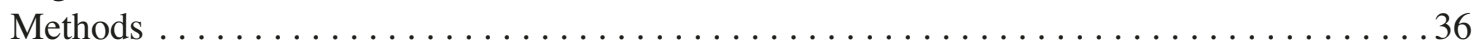

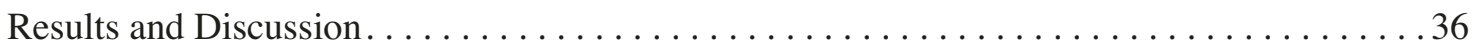

Analysis of the Faunal Remains from the Musgano Site (41RK19),

A Caddo Site in Rusk County, Texas, by LeeAnna Schniebs ...........................41

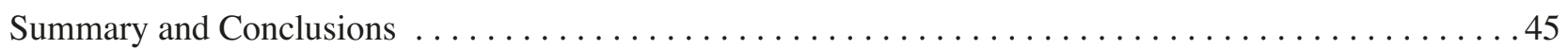

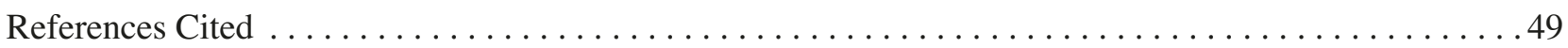




\section{List of Figures}

1. The location of the Musgano site (41RK19) in the East Texas Pineywoods $\ldots \ldots \ldots \ldots \ldots \ldots \ldots$

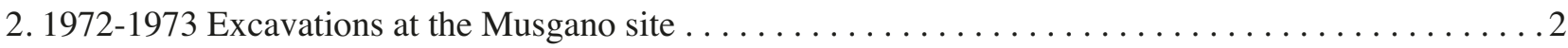

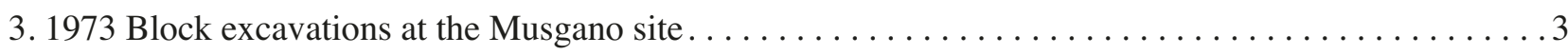

4. Profiles of sediments in the excavation block: top, West wall along the E198 line; bottom:

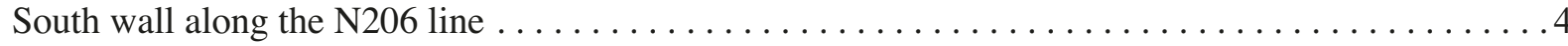

5. Summed probability distribution of calibrated radiocarbon dates from the Musgano site $\ldots \ldots \ldots \ldots 9$

6. Ceramic sherd densities in $2 \times 2$ m units excavated on the southern knoll at the Musgano site ....... 10

7. Brushed-punctated, brushed-appliqued, and incised-appliqued elements on rim and body sherds: a-b, d-e, g, brushed-punctated; c, brushed-appliqued; f, incised-appliqued . . . . . . . . 13

8. Incised elements on rim and body sherds. Figure $8 \mathrm{a}$ is petrographic sample RK19-5 $\ldots \ldots \ldots \ldots 15$

9. Incised-punctated elements on rim sherds. Note the rim peak of Figure 9h. Figure 9e

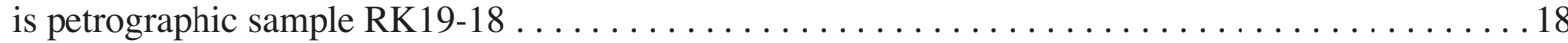

10. Incised-punctated elements on body sherds. Figure 10f is petrographic sample RK19-7; Figure 10h is petrographic sample RK19-11; Figure 10j is petrographic sample RK19-14;

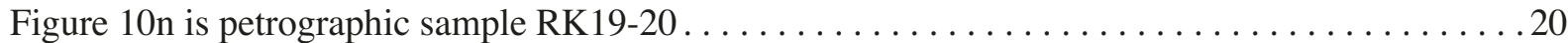

11. Washington Square Paneled rim and body sherds. Figure 11d is petrographic sample RK19-17 . . . 21

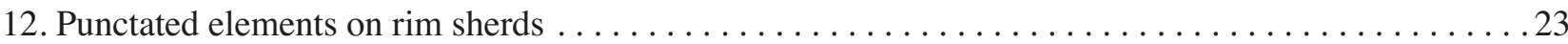

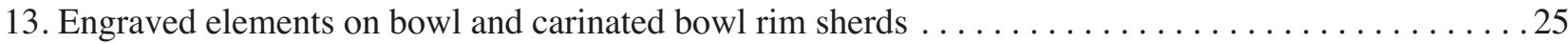

14. Engraved elements on carinated bowl body sherds. Figure $14 \mathrm{f}$ is petrographic sample

RK19-13; Figure 14g is petrographic sample RK19-16; and Figure 14j is petrographic

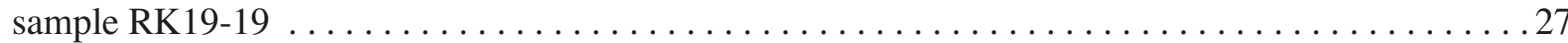

15. Engraved bottle sherds. Figure 15a is petrographic sample RK19-2 and Figure 15e

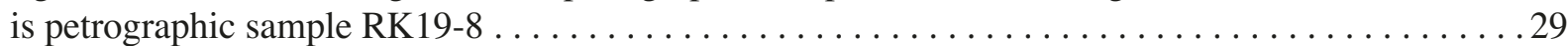

16. Holly Fine Engraved bottle sherds from the Musgano site . . . . . . . . . . . . . . . . . 30

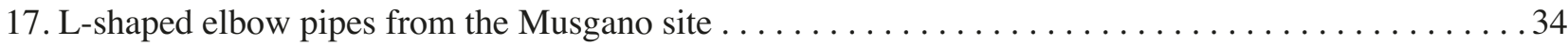

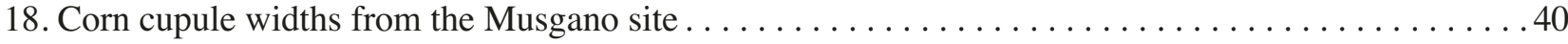




\section{List of Tables}

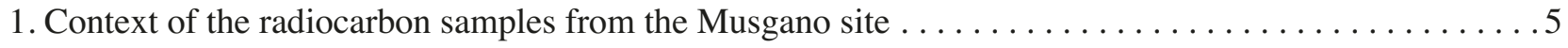

2. Calibrated radiocarbon dates from the Musgano site $\ldots \ldots \ldots \ldots \ldots \ldots \ldots \ldots \ldots \ldots \ldots \ldots \ldots \ldots \ldots \ldots \ldots \ldots$

3. Use of bone temper in the ceramic wares at the Musgano site $\ldots \ldots \ldots \ldots \ldots \ldots \ldots \ldots \ldots \ldots \ldots$

4. Decorated sherds from the Musgano site . . . . . . . . . . . . . . 12

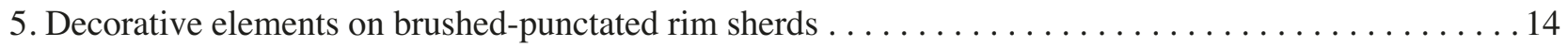

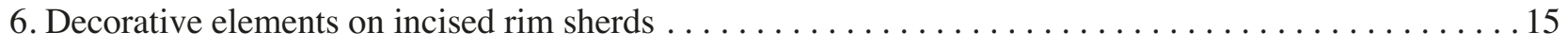

7. Decorative elements on incised-punctated $\operatorname{rim}$ sherds $\ldots \ldots \ldots \ldots \ldots \ldots \ldots \ldots \ldots \ldots \ldots \ldots \ldots \ldots \ldots \ldots$

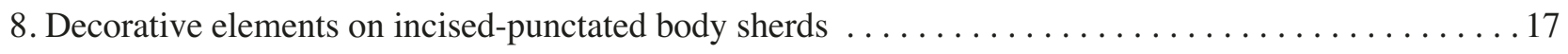

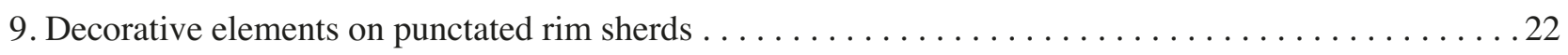

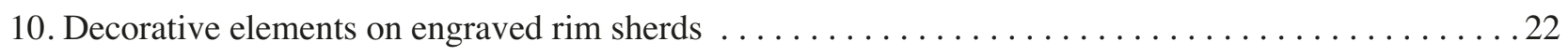

11. Decorative elements on engraved carinated bowl and bowl body sherds from the Musgano site..... 26

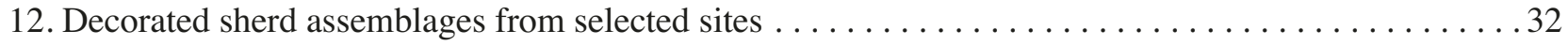

13. Temporal trends in selected assemblages with sherds with brushed elements, engraved

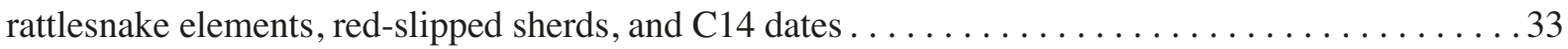

14. Plant remains from the Musgano site . . . . . . . . . . . . . 37

15. Plant remains from the Musgano site (41RK19), weights in grams $\ldots \ldots \ldots \ldots \ldots \ldots \ldots \ldots$

16. Mean corn cupule (Zea mays) measurements from selected Caddo sites . . . . . . . . . . . . 39

17. Proximate analysis of nut resources represented at the Musgano site: values per 100 grams

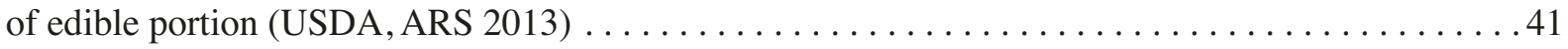

18. Summary of taxonomic recovery from the Musgano site $(41 \mathrm{RK} 19) \ldots \ldots \ldots \ldots \ldots \ldots \ldots \ldots$

19. Composition of identified elements in the Musgano site (41RK19) faunal collection ..........43

20. Summary of faunal remains from Musgano site $(41 \mathrm{RK} 19)$ features $\ldots \ldots \ldots \ldots \ldots \ldots \ldots \ldots . \ldots 4$ 


\section{Acknowledgments}

I want to thank the staff at the Texas Archeological Research Laboratory at The University of Texas at Austin for greatly facilitating this study, especially now retired Laura Nightengale. Thanks also to Leslie Bush, LeeAnna Schniebs, and Robert Z. Selden Jr. for their help with various aspects of the project and this report. Lance Trask prepared the maps and all but one figures in this article. 


\section{Introduction}

The Musgano site (41RK19) is an important ancestral Caddo habitation site on Martin Creek in Rusk County in the Sabine River basin in the East Texas Pineywoods (Figure 1). The site was investigated by the Texas Archeological Survey at The University of Texas at Austin in 1972 and 1973 prior to the construction of Martin Creek Lake by Texas Utilities Services, Inc., and a Caddo house structure, midden deposits, features, and a large ceramic assemblage were documented from a component speculated to date between ca. A.D. 1400-1500 (Clark and Ivey 1974:14-41; McDonald 1972:10-11). Unfortunately, however, the results of the excavations and the recovered artifact assemblage received only the most cursory investigation and analysis, and thus the significance of the site with respect to how it could contribute to a better understanding of the regional Caddo archaeological record has not been realized. I sought to remedy this by undertaking a reanalysis in 2013 of the existing excavation and feature records as well as the recovered artifact assemblage that are curated at the Texas Archeological Research Laboratory at The University of Texas at Austin (TARL). This report is a product of this reanalysis of the records and artifact assemblage from the Musgano site.

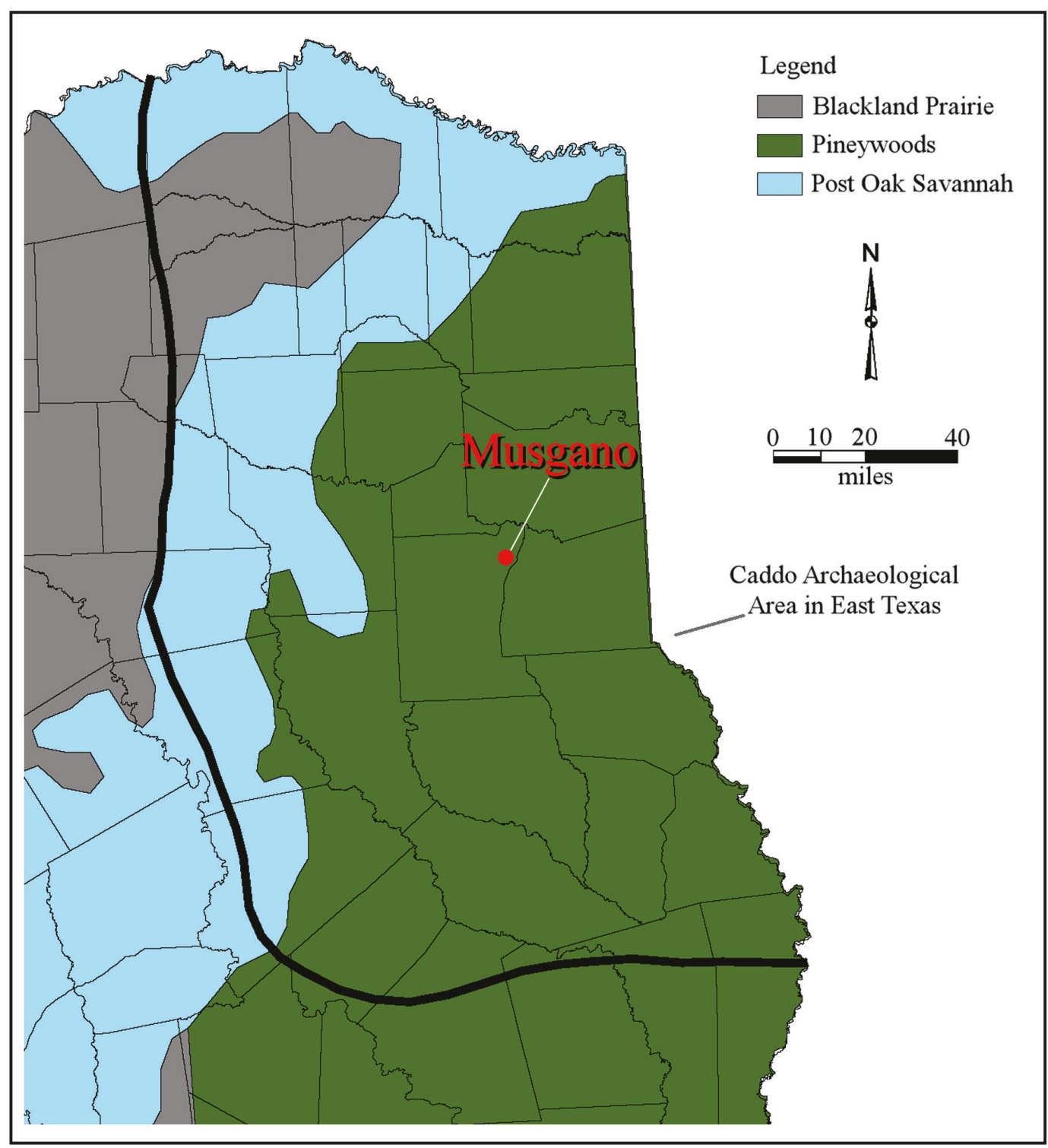

Figure 1. The location of the Musgano site (41RK19) in the East Texas Pineywoods. 


\section{Excavations and Features}

The Musgano site is located on several knolls across an eastward-projecting alluvial terrace (Griffith 2001:27-28) between Martin Creek and Wasson Branch, overlooking a spring-fed Peter Gray Slough in the Martin Creek floodplain (McDonald 1972:10; Clark and Ivey 1974:14). The upland ridge was not flooded by Martin Creek Lake, but is currently an island in the central part of the lake. The site is estimated to cover approximately 4 acres, with archaeological deposits averaging about $43 \mathrm{~cm}$ in thickness in Aand E-horizon sediments of the Attoyac series overlying an orange-red B-horizon clay. During the 1972 survey and test excavations, possible midden deposits were identified in one of the six $1 \mathrm{x} 1 \mathrm{~m}$ units; this unit lay just north of the complex of features, midden deposits, and a house structure area investigated in 1973 (Figure 2).

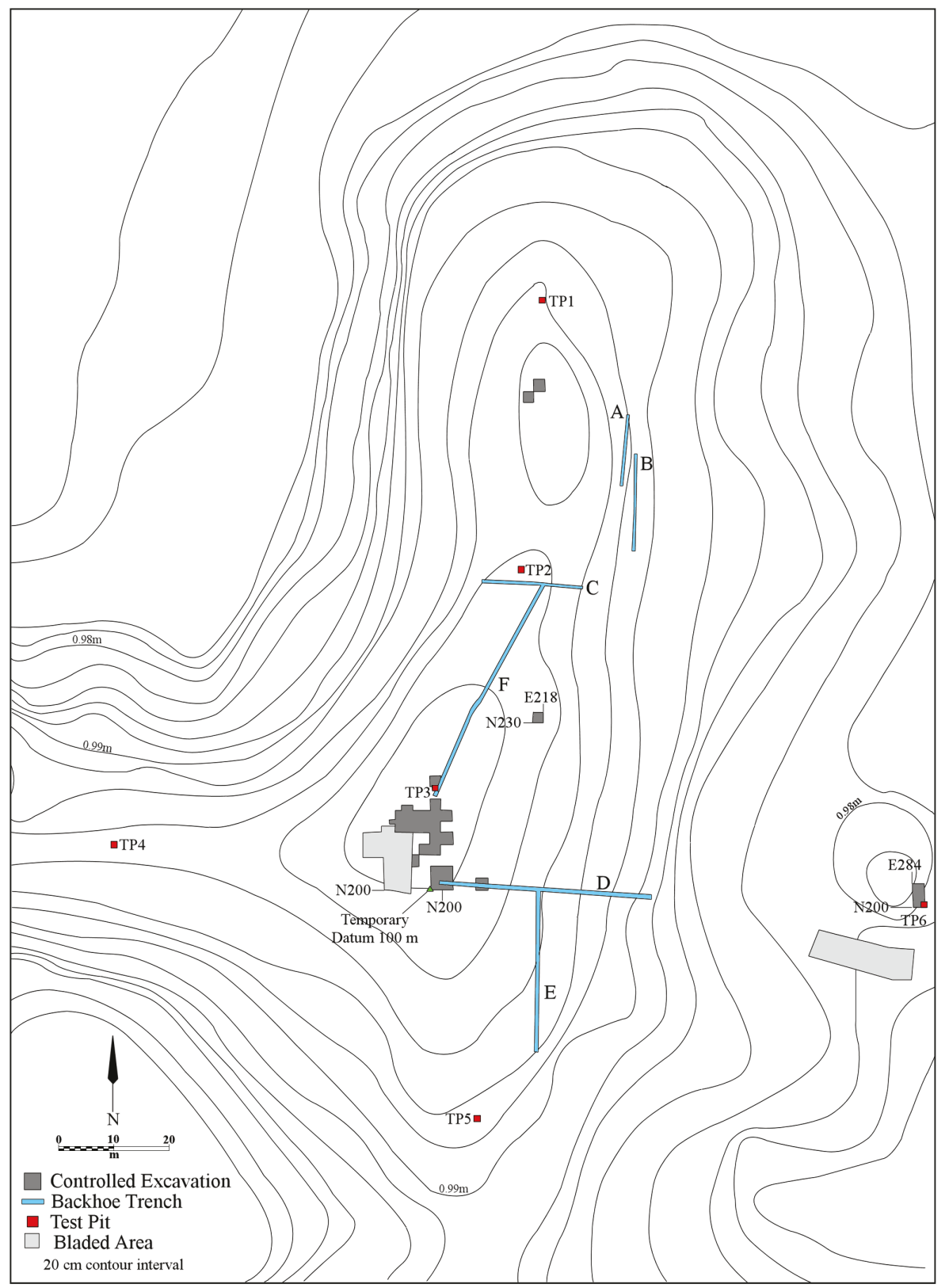

Figure 2. 1972-1973 Excavations at the Musgano site. 
The test excavations recovered 391 ceramic sherds from an ancestral Caddo occupation dispersed across the three knolls, including 104 decorated sherds (the reanalysis discussed below identified only 102 decorated sherds and two plain rim sherds from this work): brushed (40 percent), incised (38 percent; based on McDonald [1972:Figure 2i], some of the incised sherds are more likely engraved), and punctated (22 percent, including some zoned incised-punctated sherds [McDonald 1972:Figure 2q]) decorative elements. Also found in the archaeological deposits during the test excavations were a single Hayes arrow point and 54 lithic artifacts, including lithic debris, core fragments, and unifacial flake tools (McDonald 1972:10).

The Musgano site was recommended for additional archaeological investigations by McDonald (1972:11), and those investigations were carried out in 1973 (Clark and Ivey 1974:14-41); most of the excavations took place on the southernmost knoll (Clark and Ivey 1974:Figure 4). The excavations on the southern knoll consisted of an area of ca. 12 x 5 m stripped with a front end loader as well as the hand excavation of $172 \times 2 \mathrm{~m}$ units $\left(68 \mathrm{~m}^{2}\right)$; most of these units were in a contiguous block just north and east of the bladed area (Figure 3). Two 2 x 2 m units were excavated on both the northern and eastern knolls (see Figure 2), and various backhoe trenches were excavated on and in the vicinity of the northern and southern knolls.

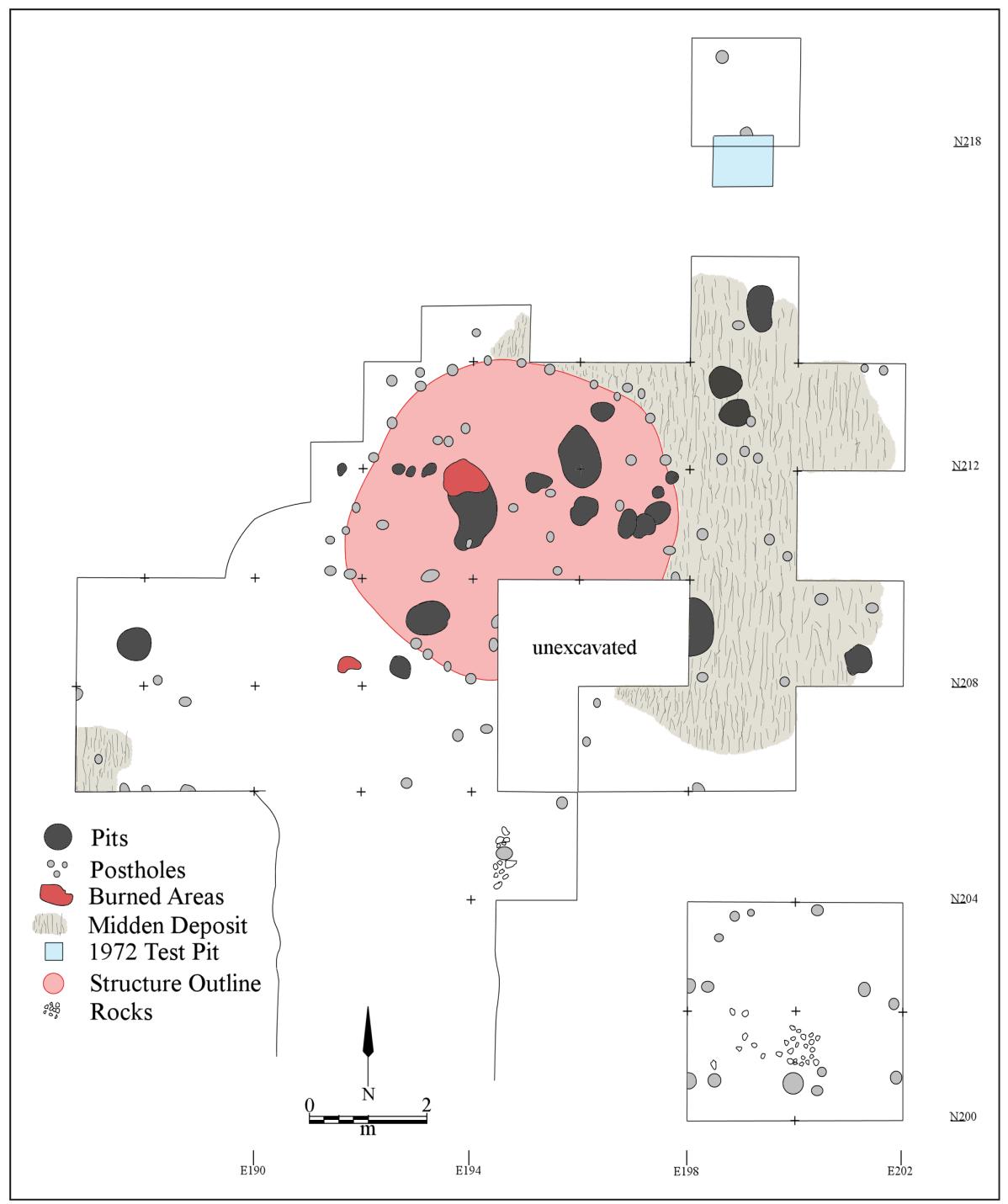

Figure 3.1973 Block excavations at the Musgano site. 
Archaeological deposits in the block area consisted of a plow zone (ca. 0-10 cm bs), followed by a dark brown sandy loam midden (ca. 10-35 cm bs) with pit and post hole features (or a brown sandy loam outside of the main midden deposits) originating from the base of this deposit, and a light tan loam (ca. $35-60 \mathrm{~cm}$ bs). These sediment zones rested on a red clayey loam subsoil (Figure 4).

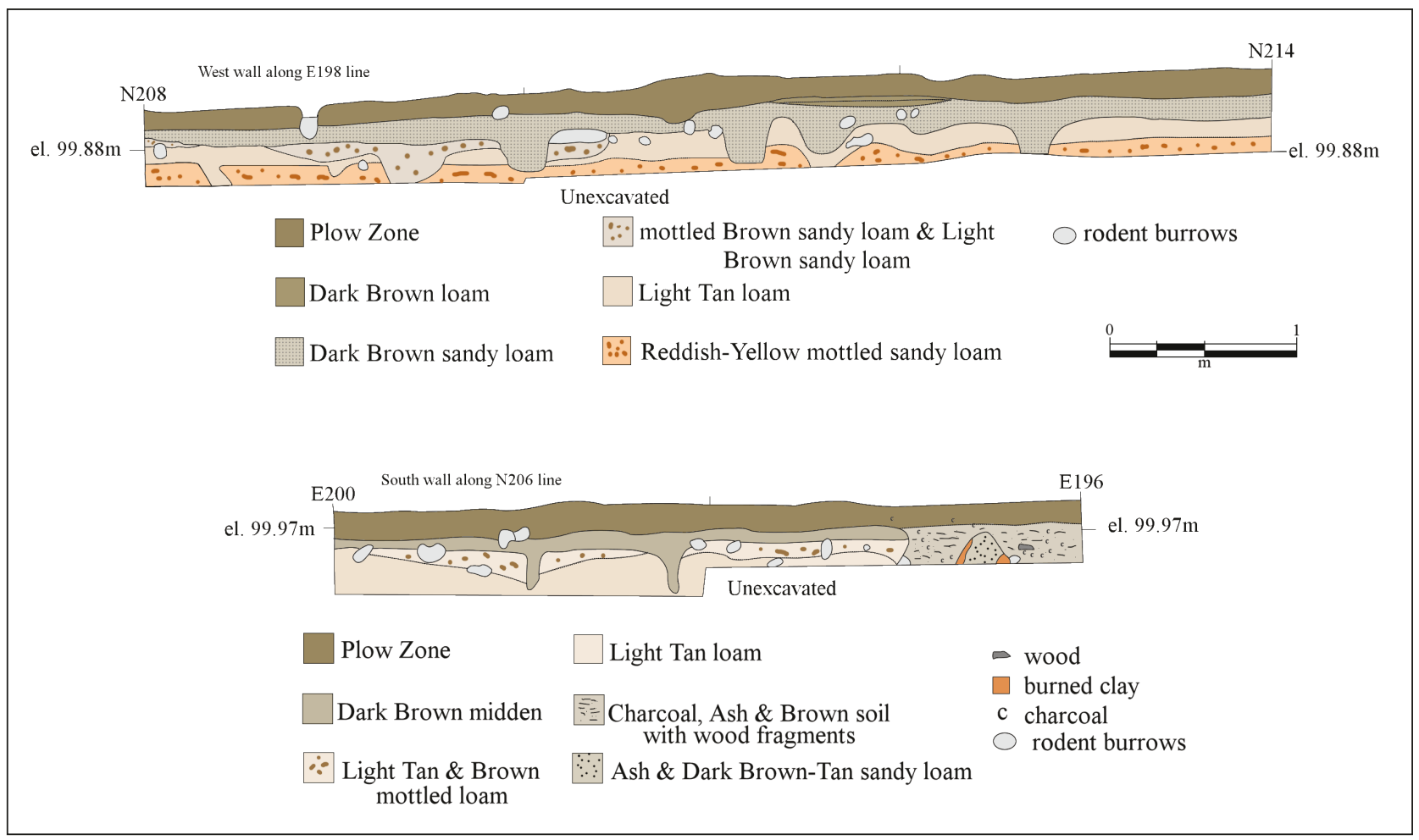

Figure 4. Profiles of sediments in the excavation block: top, West wall along the E198 line; bottom: South wall along the N206 line.

A wide variety of cultural features were identified in the block excavations and stripped area, including 90 post holes (averaging about $20 \mathrm{~cm}$ in diameter), many associated with a circular Caddo house, and several post holes that may be part of a possible granary (in unit N200-204 E198-202, see Figure 3). This feature is marked by a roughly circular pattern of posts about $3.5 \mathrm{~m}$ in diameter, a size consistent with other granaries identified and documented in East Texas Caddo sites, including George C. Davis (41CE19) and Oak Hill Village (41RK214) (Rogers and Perttula 2004; Schultz 2010). Other post holes occur in several areas outside of the structure, in outdoor work and midden areas, and these likely represent elevated work platforms, racks, and screens. The postholes in the block excavations contained a variety of artifacts and organic remains, including charcoal (40 percent of the post holes contain charcoal), corn ( 2 percent), charred nutshells ( 8 percent), animal bone (29 percent), mussel shell (1 percent), ceramic sherds ( 7 percent), and lithic debris (29 percent).

The Caddo house is circular, ca. $6 \mathrm{~m}$ in diameter. One $1.5 \mathrm{~m}$ gap in the structure wall post holes suggest that the entrance to the house was on its southwest side (see Figure 3), but because a portion of the house area was not excavated, this is not conclusive; Clark and Ivey (1974:23) suggest the entrance is on the east side, directly into the midden area. If the southwest side post hole gap does represent the house entrance, it is on the other side of the house from the midden (see Figure 3). Within the house is a ca. $40 \mathrm{~cm}$ diameter burned area, $13 \mathrm{~cm}$ in depth, that is the central hearth (Feature 100); the burned area "consisted of a shallow dish-shaped depression containing charcoal with ash scattered to the south" (Clark and Ivey 1974:22). 
The main midden deposits at the Musgano site occur immediately outside portions of the east, north, and south walls of the house (see Figure 3). It is about $9 \mathrm{~m}$ north-south and ca. $7.75 \mathrm{~m}$ east-west. A second midden deposit is present in the far western part of the block excavations (N206 E188, see Figure 3), which suggests there may be a second house and midden compound on the western part of the knoll (outside of the stripped area, see Figure 2).

Other features include pits $(\mathrm{n}=28)$ of various sizes and contents (Clark and Ivey 1974:Appendix I). Fourteen of the pits are inside the house (see Figure 3). Five pits are in the midden along the east side of the house, and the others are a few $m$ away from the west side of the house. The pits range from 14-100 $\mathrm{cm}$ in diameter, and from 10-62 $\mathrm{cm}$ in depth. About 54 percent $(\mathrm{n}=15)$ are more than $40 \mathrm{~cm}$ in diameter, and the rest are small pits less than $40 \mathrm{~cm}$ in diameter (some may actually be larger post holes). The larger pits are probably storage pits that eventually were disused and trash was thrown into them for disposal. These pits contained charcoal ( $\mathrm{n}=53$ percent of the large pits), nut shell ( 27 percent), corn ( 25 percent), animal bone (53 percent), mussel shell (13 percent), ceramic sherds (40 percent), chipped stone tools ( 7 percent, including a Perdiz arrow point from Feature 14), and lithic debris (47 percent). The smaller pits $(n=13)$ had lesser quantities of charcoal (i.e., 31 percent of the small pits had charcoal), nut shells (23 percent), animal bones (23 percent), mussel shell ( 8 percent), ceramic sherds ( 15 percent), and lithic debris (15 percent).

\section{Age of the Archaeological Deposits, Timothy K. Perttula and Robert Z. Selden, Jr.}

There is an extensive radiocarbon database for East Texas, with more then 900 dates from Caddo sites (Perttula and Selden 2011; Selden and Perttula 2013). However, no absolute dates from the Musgano site were available when this analysis began, and the age of the site was unknown. There were at least two pit features at the site (Features 56 and 178) that apparently contain corn (Clark and Ivey 1974:22), and there are others (see Bush, this volume); nut shells are also common constituents of the many pit features at the site (Clark and Ivey 1974:Appendix I). As part of the reanalysis of the Musgano site excavations, six samples of organic remains (i.e., corn, Carya sp. nutshells, cane stem, and Quercus sp. carbonized nutmeat) were submitted from features for AMS radiocarbon dating, following the approval of TARL (Table 1). Before the radiocarbon samples from features were submitted for AMS dating, Leslie Bush (Macrobotanical Analysis, Manchaca, Texas) examined them in detail to identify, sort, and weigh all preserved organic remains (see below). Only charred corn or hickory nutshells were submitted for radiocarbon dating, and any other preserved organic remains in the sample have been retained by TARL.

Table 1. Context of the radiocarbon samples from the Musgano site.

\begin{tabular}{lll}
\hline Lab No. & Sample No. & TARL Information \\
\hline D-AMS 004813 & AEC-29 & Feature 16, lot 63, corn cupules \\
D-AMS 004814 & AEC-30 & Feature 14, lot 62, Carya sp. nutshells \\
D-AMS 004815 & AEC-31 & Feature 3, corn cupules \\
D-AMS 004816 & AEC-32 & Feature 3, cane stem \\
D-AMS 004817 & AEC-33 & Lot 145/146, Quercus sp. nutmeat \\
D-AMS 004818 & AEC-34 & Feature 16, lot 63, corn cupules \\
\hline
\end{tabular}

The results of the radiocarbon dating of organic remains from the archaeological deposits at the Musgano site indicate that the primary Caddo occupation took place between A.D. 1250-1440 (based on OxCal v4.2.3), during the Middle Caddo period (Figure 5). The principal peaks in probability density occur 
at ca. A.D. 1260-1280 and A.D. 1400-1440, and the calibrated median ages range from A.D. 1278-1431 (Table 2).

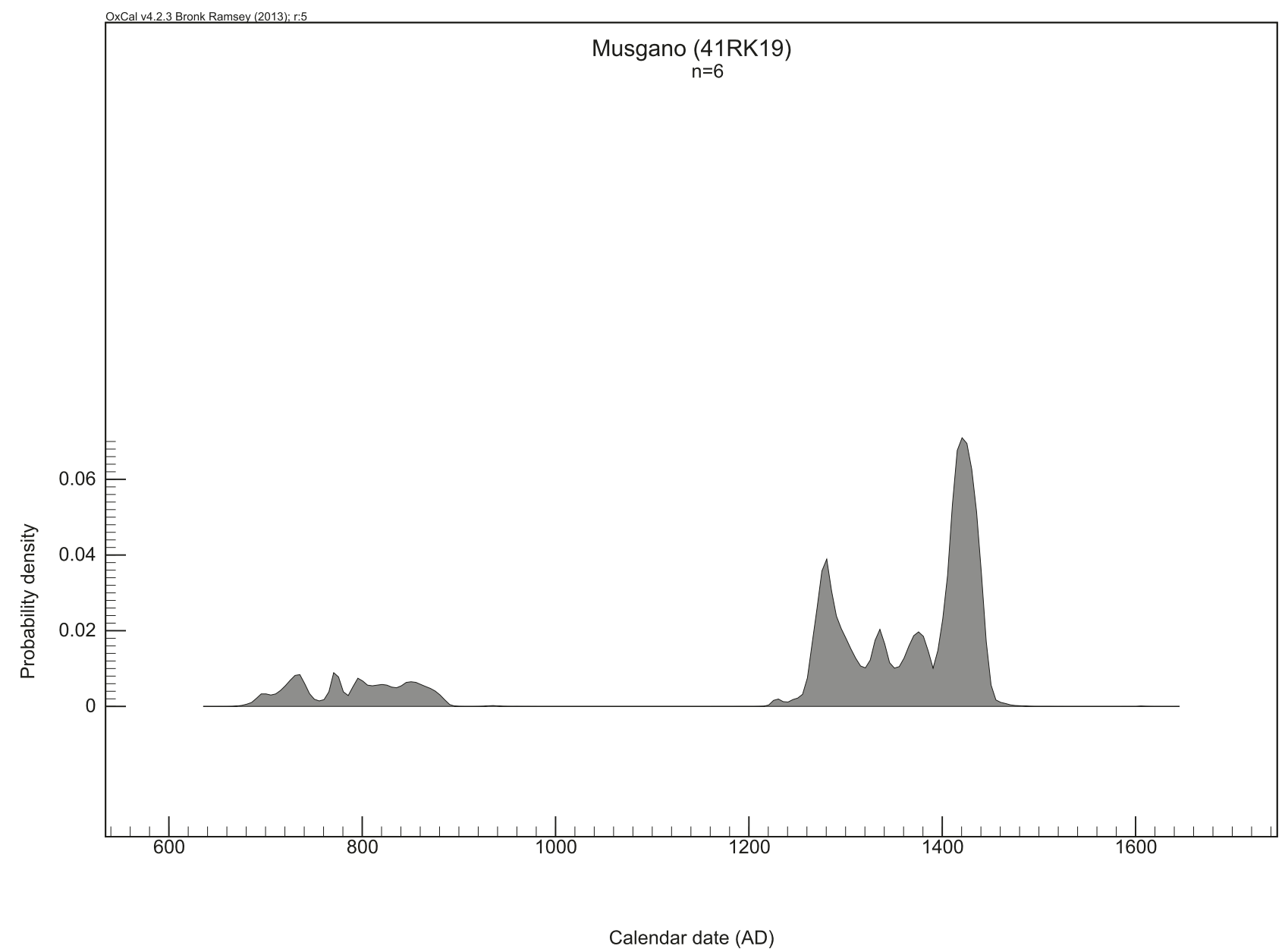

Figure 5. Summed probability distribution of calibrated radiocarbon dates from the Musgano site. 
Table 2. Calibrated radiocarbon dates from the Musgano site.

\begin{tabular}{lclc}
\hline Lab No. & $\begin{array}{l}\text { Conventional 14C } \\
\text { Age (B.P.) }\end{array}$ & $\begin{array}{l}\text { Two Sigma (A.D.) } \\
\text { Calibrated Age }\end{array}$ & $\begin{array}{l}\text { Median } \\
\text { Calibrated } \\
\text { Age (A.D.) }\end{array}$ \\
\hline 004813 & $1227 \pm 29$ & $689-750(0.29)$, & 795 \\
004814 & $721 \pm 31$ & $\begin{array}{l}760-885(0.67) \\
1244-1302(0.89)\end{array}$ \\
004815 & $645 \pm 27$ & $1282-1325(0.42)$, & 1278 \\
004816 & $518 \pm 28$ & $1344-1395(0.54)$ & 1354 \\
004817 & $480 \pm 31$ & $1327-1343(0.07)$, & 1418 \\
004818 & $540 \pm 30$ & $1394-1443(0.89)$ & 1431 \\
& & $1316-1354(0.95)$ & \\
\hline
\end{tabular}

Disregarding the 7th and 8th century calibrated age ranges from D-AMS 004813 (corn from Feature 16), which are completely contradicted by the other dates from the Musgano site and the second date on corn from Feature 16 (D-AMS 004818), the calibrated age ranges with the highest probabilities (ranging from 0.54-0.95) at 2 sigma for the five remaining dates are: A.D. 1244-1302, A.D. 1344-1395, A.D. 1394-1443, A.D. 1405-1455, and A.D. 1389-1437. Four of these age ranges fall from A.D. 1344-1455 (see Table 2). It is likely that this period represents the principal Caddo occupation of the Musgano site during the latter years of the Middle Caddo period in the mid-Sabine River basin. 


\section{Analysis of the Ceramic Assemblage}

The stylistic analysis of Caddo ceramics from the Musgano site focuses on the definition of recognizable decorative motifs and elements in the fine wares (i.e., the engraved and red-slipped vessels, including carinated bowls and bottles) and utility wares, usually cooking or storage jars and simple bowls. These wares are known to have been made and used differently, based on functional, technological, and stylistic analyses on numerous Caddo sherd assemblages in the broader East Texas region, with uses ranging from food service, cooking of food stuffs, as containers for liquids, and for plant food/seed crop storage. The more detailed consideration of ceramic stylistic variability and diversity in the Musgano ceramic assemblage focuses on decorative elements that can be identified on rim and body sherds. These represent distinct designs or design combinations and elements (i.e., the breakdown of individual decorations within an overall design motif, as in a hatched triangle, circle, or tick marks) that can be identified on sherds and vessel sections (even if it is only a portion of the element), as a recurrent feature of decoration within each of the major decorative methods (e.g., incising, punctating, engraving, etc.) present in the Caddo ceramic assemblage. The design elements are defined at different levels of association, depending upon variations in the designs (e.g., the number and spacing of engraved lines on a rim), the location of the decoration (e.g., on the rim, body, on the vessel interior, etc.), and the method of decoration (e.g., horizontal vs. vertical brushing). When sherds large enough to exhibit overall design motifs are present in the assemblage, typological classifications are possible.

The utility ware vessels found on ancestral Caddo sites in East Texas were used for cooking, storage, and probably other culinary activities; they tend to have a coarse paste, thick or thicker body walls, have smoothed interior surfaces, and are decorated with wet-paste designs (i.e., decorations were made with tools and fingers prior to the vessel being fired, when the vessel had a wet exterior surface) (Perttula 2013). Fine wares are engraved and red-slipped vessels that were used for food service and to hold liquids, as well as for other purposes (i.e., effigy vessels). They tend to have fine pastes, with finely crushed tempers, are frequently burnished on interior and/or exterior vessel surfaces (except the bottles, which were burnished on exterior surfaces only), and have relatively thin body walls compared to the utility wares. The engraved decorations are etched into the exterior vessel surface after the vessel has been fired or is leather-hard.

More specifically, the detailed analysis of the decorated ceramic sherds from the Musgano site also is based on differences in temper (specifically the presence or absence of bone as a temper, in an otherwise grog temper-dominated assemblage), type of sherd (i.e., rim or body), and rim and lip form (cf. Brown 1996:Figure 2-12). Although most of the sherds are small and thus from indeterminate vessel forms, where sherds were large enough, vessel form categories that could be identified include open containers (bowls and carinated bowls) and restricted containers, including jars and bottles. Other form attributes include rim profile (outflaring or everted, direct or vertical, and inverted) and lip profile (rounded, flat, or folded to the exterior, among others).

Brushing, a popular method of roughening the surface of Middle, Late, and Historic Caddo cooking jars in this part of the Sabine River basin with stiff bundles of grasses, is considered a decorative treatment here rather than solely a functional surface treatment (cf. Rice 1987:138). A roughened and brushed pot would certainly have been easier to pick up and carry than would an unroughened or smoothed vessel, but because the brushing was applied to be an integral part of the decoration of both rim and body vessel surface, I de-emphasize it as a surface treatment.

The application of a hematite-rich clay slip, black after firing in a reducing environment, is another form of surface treatment noted in this assemblage, although it is not common. The clay slip was typical- 
ly applied to the vessel exterior or both surfaces, and then was burnished or polished after it was leatherhard or dry; when the vessel was fired, it created a thin red slip. In other instances, a kaolin-rich clay (i.e., white pigment) or a hematite-rich clay (i.e., red pigment) may be applied as a pigment to the decoration on engraved ceramic vessels.

Besides sherds with a red slip, decorative techniques present in the Musgano site ceramic sherd collections include engraving, incising, punctation, brushing, pinching, and appliqué, and on certain sherds, combinations of decorative techniques (i.e., brushed-incised and brushed-appliqued, or incised-punctated sherds) created the decorative elements and motifs, with one motif on the rim and another on the vessel body (Schambach's Rule of Two). Engraving and the excising of punctations on fine wares was done with a sharp tool when the vessel was either leather-hard or after it was fired, while the other decorative techniques were executed with tools or fingers (incising, trailing, punctations, and pinching with wood or bone sticks or dowels), by adding strips of clay to the wet body (appliqué), using frayed sticks or grass stems (brushing) across the vessel surface, or corrugating vessel coils when the vessel was wet or still plastic to create a series of neck bands. Excising is considered a form of engraved decoration, where the clay is deliberately and closely marked/scraped and carved away with a sharp tool, usually to create triangular elements or crescentshaped elements separating or defining scrolls. A red clay film or wash may be added to the surface (interior and/or exterior surfaces) of some vessels as a slip (or a coating) before they were fired.

The ceramic assemblage from the survey, testing, and data recovery efforts at the Musgano site includes 32 plain rim sherds, 2096 decorated rim and body sherds, a single spindle whorl made from a base sherd, and a clay ear spool with a central groove; one end of the spool has a large drilled circular cavity in it. No plain body or base sherds were examined in this study, and sherdlets (less than $1.5 \mathrm{~cm}$ in diameter) were also not examined herein.

\section{Spatial Distribution of the Ceramic Sherds}

Based on the information presented in Clark and Ivey (1974:Table 1), ancestral Caddo ceramic sherds are abundant at the Musgano site on the three knolls dispersed across the alluvial terrace (see Figure 2). These ceramic sherds are from one contemporaneous occupation, with brushed utility wares common in all three areas. The sherd density on the southern knoll (i.e., the focus of the excavations) ranges from 43.3-191 sherds per $\mathrm{m}^{2}$, while the sherd density on the eastern knoll is 23.5-38.5 sherds per $\mathrm{m}^{2}$. On the northern knoll, the sherd density is 74.8-93.8 per $\mathrm{m}^{2}$. These densities suggest that all three knolls at the Musgano site have habitation deposits, each likely including structures and midden deposits.

On the southern knoll itself, the highest sherd densities (greater than 179 sherds per $\mathrm{m}^{2}$ ) are in the northeastern quadrant of the structure itself and in the midden deposits just outside that portion of the structure (Figure 6). Sherd densities between 91-129 per $\mathrm{m}^{2}$ are found in a ca. $10 \mathrm{x} 8 \mathrm{~m}$ area that falls within the structure and encompasses almost all of the midden deposits along the eastern side of the structure (see Figure 3). Sherd densities decrease to 43-66 per $\mathrm{m}^{2}$ in areas of excavations that are both to the north and south of the midden deposits.

\section{Plain Ware Rim Sherds}

There are 32 rim sherds from plain wares in the Musgano ceramic assemblage. This represents 15.4 percent of all the rim sherds in the collection $(n=208)$, indicating that plain ware vessels (jars and bowls, primarily) are well represented at the site. This compares to 23 fine ware rim sherds (only 11 percent of the rim sherds from the site) and 153 utility ware rim sherds (73.6 percent of the site's rim sherds). 


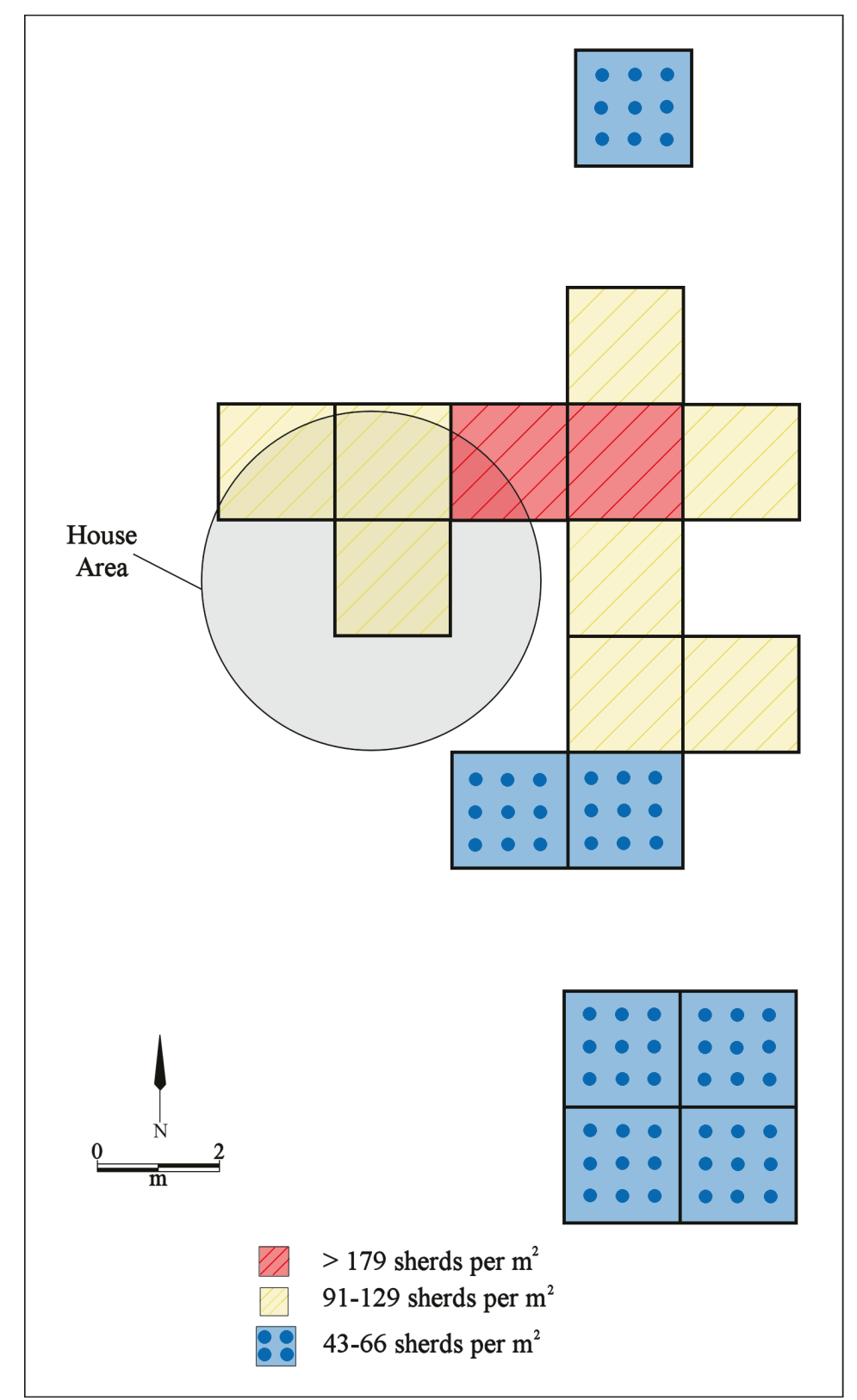

Figure 6. Ceramic sherd densities in $2 \times 2$ m units excavated on the southern knoll at the Musgano site.

Where it could be determined based on the size of the rim sherd, the plain rims have direct or vertical orientations ( $n=28,88$ percent) as well as everted orientations ( $n=1,3$ percent); the rim profile could not be determined on three rim sherds. The rim sherds have flat $(n=5,15.6$ percent), rounded $(n=22,69$ percent), or rounded with exterior folded ( $n=5,15.6$ percent) lips.

Almost 16 percent of the plain ware rims are from vessels tempered with bone; the remainder are from grog or grog-hematite-tempered vessels (Table 3). Only between 8.2-11.6 percent of the fine wares and utility wares are from bone-tempered vessels. The highest percentage of bone-tempered vessels among the utility wares are found in sherds from vessels with brushed-incised (16.5 percent), brushedpunctated (17.5 percent), and brushed-appliqued (23.1 percent) decorative elements. Overall, 11.3 percent of all the analyzed sherds from the Musgano site are from bone-tempered vessels. 
Table 3. Use of bone temper in the ceramic wares at the Musgano site.

\begin{tabular}{lcc}
\hline Ware & No. of sherds & Percent bone-tempered \\
\hline Plain & 32 & 15.6 \\
Utility & 1913 & 11.6 \\
Fine & 183 & 8.2 \\
\hline Totals & 2128 & 11.3 \\
\hline
\end{tabular}

In other generally contemporaneous Caddo ceramic assemblages in the mid-Sabine River basin, the use of bone temper by Caddo potters is quite variable both spatially and temporally. At 41RK557, a ca. 14th-mid-15th century site, 52 percent of the sherds are bone-tempered (Dockall and Fields 2011), and at 41RK243, 78 percent of the sherds are bone-tempered (Perttula 2001). Conversely, at 41RK240 and 41RK242, between 16.5-19 percent of the sherds are bone-tempered (Perttula 2001), roughly comparable to the Musgano assemblage, and 24 percent of the sherds from 41HS74 are bone-tempered (Heartfield, Price, and Greene, Inc. 1988). At 41HS588, a 14th to early 16th century occupation, sherds from bonetempered vessels account for 38 percent of the sherds (Dockall et al. 2008), compared to 49 percent at 41HS573, a post-A.D. 1450 occupation, 37 percent at 41HS574, 36 percent at 41HS844, and 29 percent at $41 \mathrm{HS} 846$ (Gadus et al. 2006).

\section{Utility Ware Sherds}

More than 91 percent of the decorated sherds from the Musgano site are from utility ware vessels $(n=1913)$ (Table 4). Among the decorated rim sherds, 87 percent are from utility ware vessels, particularly vessels with punctated, incised-punctated, incised, brushed, and brushed-punctated decorative elements.

Table 4. Decorated sherds from the Musgano site.

\begin{tabular}{|c|c|c|c|c|}
\hline Decorative Method & Rim & Body & Percentage & $\mathrm{N}$ \\
\hline
\end{tabular}

Utility ware

$\begin{array}{lrrrr}\text { Appliqued } & - & 10 & 0.5 & 10 \\ \text { Brushed } & 15 & 753 & 36.6 & 768 \\ \text { Brushed-appliqued } & - & 13 & 0.6 & 13 \\ \text { Brushed-incised } & 3 & 76 & 3.8 & 79 \\ \text { Brushed-incised-appliqued } & - & 1 & \text { Trace } & 1 \\ \text { Brushed-punctated } & 9 & 31 & 1.9 & 40 \\ \text { Incised } & 24 & 335 & 17.1 & 359 \\ \text { Incised-appliqued } & - & 1 & \text { Trace } & 1 \\ \text { Incised-punctated } & 43 & 28 & 10.6 & 223 \\ \text { Pinched } & 1 & 331 & 1.4 & 29 \\ \text { Punctated } & 58 & 1 & 18.5 & 389 \\ \text { Stamped } & - & & \text { Trace } & 1\end{array}$


Table 4. Decorated sherds from the Musgano site, cont.

\begin{tabular}{|c|c|c|c|c|}
\hline Decorative Method & Rim & Body & Percentage & $\mathrm{N}$ \\
\hline \multicolumn{5}{|l|}{ Fine ware } \\
\hline Engraved & 23 & 157 & 8.6 & 180 \\
\hline Red-slipped & - & 3 & 0.1 & 3 \\
\hline Totals & 176 & 1920 & 100.0 & 2096 \\
\hline
\end{tabular}

The varying proportion of decorated rim to decorated body sherds among the different categories of utility wares suggest that brushed-punctated, incised-punctated, and punctated decorations are more likely to be found on the vessel rim (ratios of 1:3.4,1:4.2, and 1:5.7, respectively) compared to the other decorative categories. There are no rim sherds with appliqued and brushed-appliqued decorative elements and the decorated rim to decorated body sherd ratios are 1:50.2 for the brushed sherds; 1:25.3 for the brushed-incised sherds; 1:14.0 for the incised sherds, and 1:28.0 for the pinched sherds. These decorative methods are to be found, then, on both the rim and the body of utility ware vessels, most commonly cooking jars.

\section{Appliqued}

All 10 of the appliqued sherds are decorative embellishments on the bodies of utility ware jars. The decorative elements include parallel appliqued ridges $(n=1)$, a straight appliqued ridge $(n=3)$, a straight appliqued fillet $(\mathrm{n}=3)$, a straight appliqued fillet and an appliqued node $(\mathrm{n}=1)$, and single appliqued nodes $(n=2)$. The appliqued ridges and fillets, as well as the nodes, likely were used to create vertical panels (probably four) on vessel bodies, but in these cases the panels were left undecorated.

\section{Brushed}

The rims of brushed utility ware vessels have brushing marks that are oriented either diagonally $(n=1)$ or horizontally around the vessel $(n=14)$; one of the vessels has a rim peak. Body sherds have curvilinear ( $n=1,0.1$ percent), opposed $(n=16,2.1$ percent), overlapping $(n=12,1.6$ percent), parallel $(n=720,95.3$ percent), and vertical $(n=4,0.5$ percent) brushing marks; although the orientation of the parallel brushed body sherds is unknown, it is likely that the brushing on these sherds is also oriented vertically on the bodies of jars. These brushed sherds are probably from Bullard Brushed jars (Suhm and Jelks 1962:21 and Plate 11).

\section{Brushed-Appliqued}

The 13 brushed-appliqued sherds are from the bodies of utility ware jars, probably of the Pease Brushed-Incised type (Suhm and Jelks 1962:119). The decorative elements on the sherds include parallel brushing marks adjacent to, or on either side of, a straight appliqued fillet $(n=12)$, and a straight appliqued fillet with opposed brushing marks $(\mathrm{n}=1)$ (Figure $7 \mathrm{c}$ ). The appliqued fillets likely are oriented vertically on the body, creating vertical panels filled with brushing oriented either vertically or horizontally. 


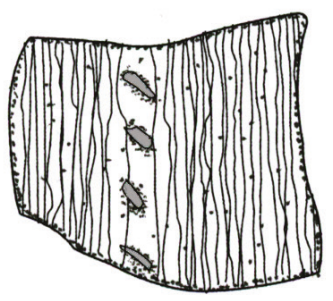

a
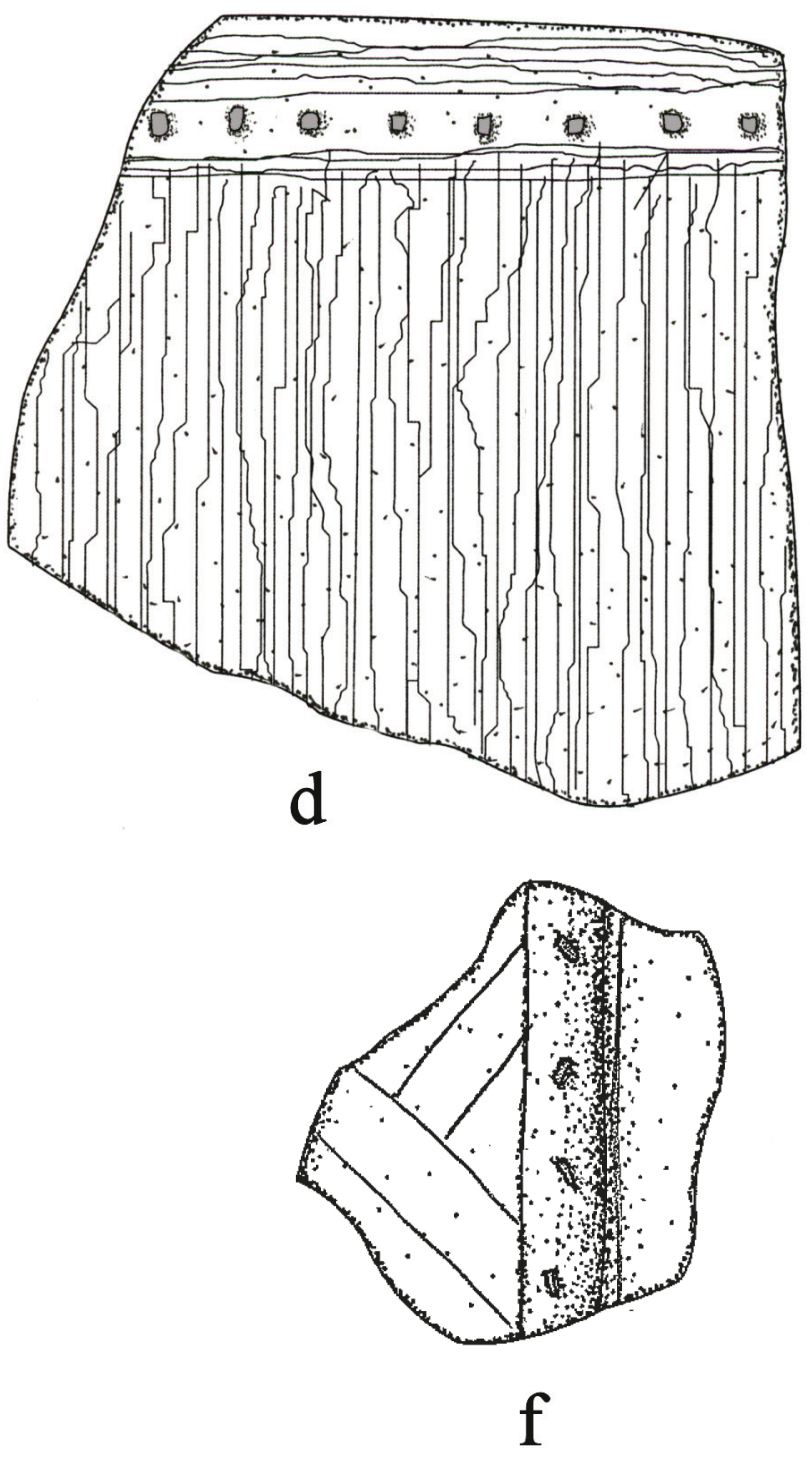

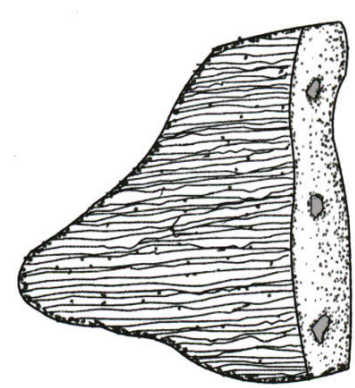

C
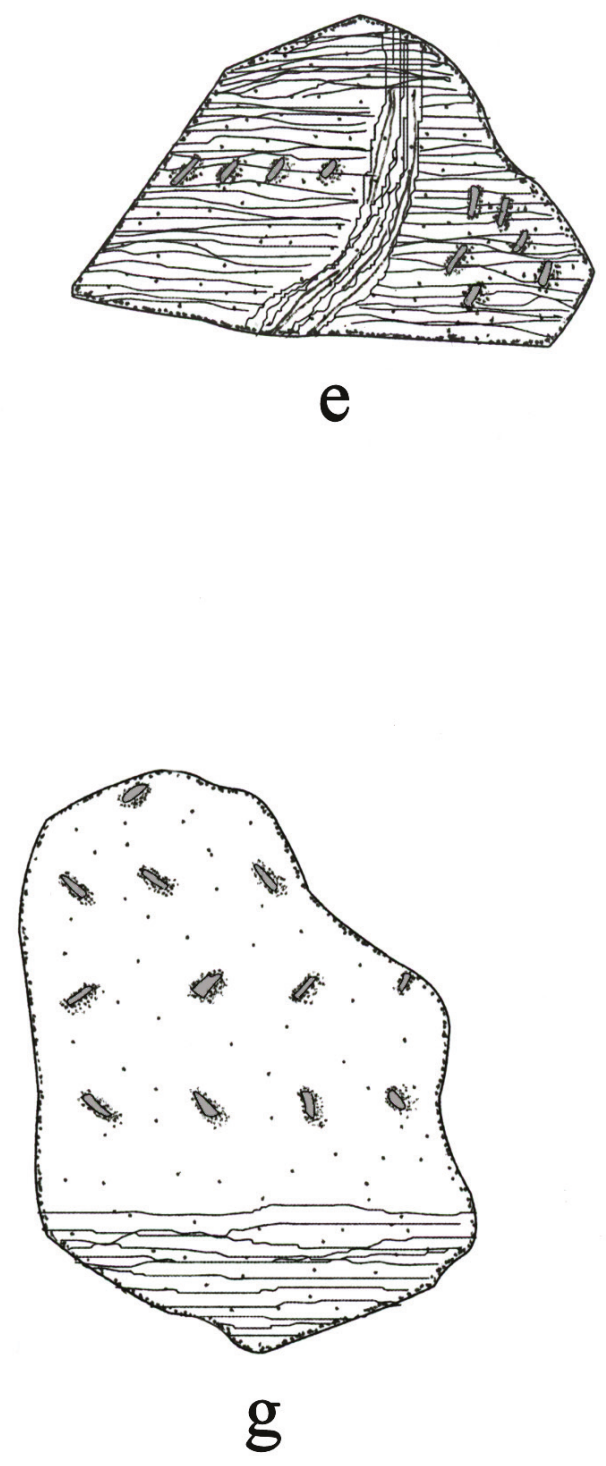

Figure 7. Brushed-punctated, brushed-appliqued, and incised-appliqued elements on rim and body sherds: a-b, d-e, g, brushed-punctated; c, brushed-appliqued; f, incised-appliqued. 


\section{Brushed-Incised}

Sherds with brushed-incised decorative elements comprise 3.8 percent of the decorated sherds from the Musgano site, and 4.1 percent of the utility wares (see Table 4). The rim sherds $(n=3)$ have horizontal brushed-incised marks and lines. The decorative elements on body sherds include: curvilinear brushedincised marks and lines ( $\mathrm{n}=1,1.3$ percent), opposed brushed-incised marks and lines $(\mathrm{n}=2,2.6$ percent), parallel brushed-incised marks and lines ( $n=55,72.4$ percent), parallel brushed marks with an adjacent straight incised line ( $n=1,1.3$ percent), parallel brushed marks with overlapping sets of parallel incised lines $(n=15,19.7$ percent $)$, parallel brushed marks and an overlapping set of cross-hatched lines $(n=1$, 1.3 percent), and vertical brushed-incised marks and lines ( $n=1,1.3$ percent). As with the brushed body sherds, the orientation of the parallel brushed-incised body sherds is unknown; it is likely that the brushing-incised lines on these sherds are also oriented vertically on the bodies of jars.

\section{Brushed-Incised-Appliqued}

The one brushed-incised-appliqued body sherd in the assemblage has parallel brushed-incised marks and lines on either side of a straight appliqued ridge. The appliqued ridges likely created panels filled with brushed-incised lines on the vessel body.

\section{Brushed-Punctated}

Sherds with brushed-punctated decorative elements comprise 5.9 percent of the utility ware rims and 2.1 percent of all the utility wares from the Musgano site (see Table 4). Rims primarily have horizontal brushing marks, with at least one row of tool punctates - under the lip, at the mid-rim, and at the rimbody juncture-sometimes pushed through the brushing, but mainly serving to divide the brushing into horizontal panels (Table 5).

Table 5. Decorative elements on brushed-punctated rim sherds.

\begin{tabular}{lcc}
\hline Decorative element & No. & Percent \\
\hline $\begin{array}{l}\text { diagonal brushed with a row of tool punctates under lip } \\
\text { horizontal brushed with rows of tool punctates under lip, } \\
\text { mid-rim, and at rim-body juncture (see Figure 7b) } \\
\text { horizontal brushed with a row of tool punctates under lip } \\
\begin{array}{l}\text { horizontal brushed with rows of tool punctated pushed } \\
\text { through the brushing }\end{array}\end{array}$ & 1 & 11.1 \\
\hline
\end{tabular}

There is one brushed-punctated lower rim-body sherd in the Musgano assemblage. It has horizontal brushing marks on the lower part of the rim, a row of tool punctates at the rim-body juncture, and diagonal brushing marks on the vessel body (see Figure 7d). Body sherds with brushed-punctated decorative elements include: diagonal brushing with an adjacent row of tool punctates ( $n=2,6.7$ percent); opposed brushing marks with a row of tool punctates pushed through the brushing ( $\mathrm{n}=2,6.7$ percent); diagonal opposed brushing marks on either side of a row of tool punctates $(n=1,3.3$ percent); parallel brushing marks adjacent to a tool punctated row or rows $(\mathrm{n}=8,26.7$ percent, see Figure $7 \mathrm{~g})$; parallel brushed with a row of tool punctates pushed through the brushing $(\mathrm{n}=16,53.3$ percent, see Figure $6 \mathrm{a})$; and parallel and curvilinear brushed with rows of tool punctates pushed through the brushing ( $n=1,3.3$ percent, see Figure 7e). 


\section{Incised}

The utility wares with incised decorative elements are dominated by vessels with a series of either diagonal or horizontal incised lines (Table 6); these account for 79.2 percent of the incised rims in the assemblage. Other rims have diagonal opposed or chevron elements (Figure 8h), vertical lines, and crosshatched lines. Most of these are from Maydelle Incised vessels (Suhm and Jelks 1962:103 and Plate 52).

Table 6. Decorative elements on incised rim sherds.

\begin{tabular}{lrr}
\hline Decorative element & No. & Percent \\
\hline cross-hatched lines & 1 & 4.2 \\
diagonal lines & 12 & 50.0 \\
diagonal opposed lines (see Figure 8h) & 2 & 8.3 \\
horizontal lines & 7 & 29.2 \\
vertical lines & 2 & 8.3 \\
\hline Totals & 24 & 100.0 \\
\hline
\end{tabular}

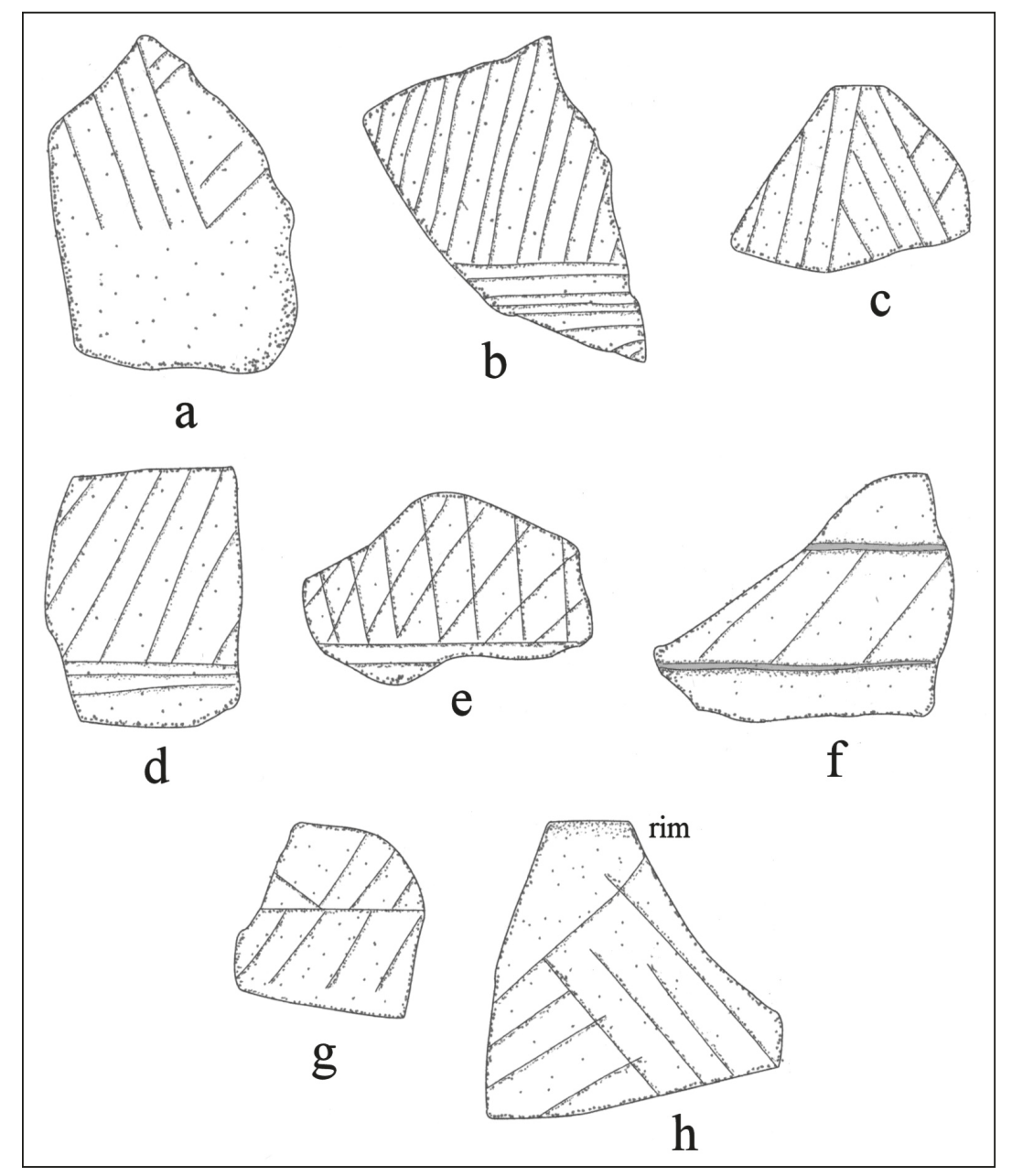

Figure 8. Incised elements on rim and body sherds. Figure 8a is petrographic sample RK19-5. 
Body sherd decorations in this utility ware also emphasize straight-line incised elements, including cross-hatched lines ( $n=3,0.9$ percent), cross-hatched and horizontal lines $(n=2,0.6$ percent, see Figure 8 e), diagonal lines ( $n=1,0.3$ percent), diagonal opposed lines $(n=8,2.4$ percent, see Figure 8 a, c), diagonal and horizontal lines $(n=5,1.5$ percent, see Figure $8 b, d, g)$, a hatched incised zone $(n=2,0.6$ percent, see Figure 8f), opposed lines ( $n=27,8.1$ percent), parallel lines $(n=179,53.4$ percent), rectilinear lines $(n=1,0.3$ percent), an incised triangle element $(n=1,0.3$ percent), vertical lines $(n=1,0.3$ percent), and body sherds with only a single straight line ( $\mathrm{n}=99,29.5$ percent). Only six body sherds (1.8 percent) have single or multiple curvilinear incised lines as the decorative element.

\section{Incised-Appliqued}

This body sherd has a straight appliqued fillet with a parallel incised line on one side of the fillet, and diagonal opposed incised lines on the other side (see Figure 7f).

\section{Incised-Punctated}

There are a variety of distinct decorative elements on utility ware jar rims with incised-punctated designs (Table 7 and Figure 9a-j). The rims with diagonal, diagonal opposed, horizontal, and curvilinear line elements are from Maydelle Incised jars, and tend to have rows of punctations under the lip and at the rim-body juncture. The remainder of the incised-punctated rim sherds have incised triangles, zones, and panels that are filled with tool punctates; they do not have rows of punctations under the lip or at the rim-body juncture. These zoned incised-punctated sherds, also from Maydelle Incised vessels (Suhm and Jelks 1962:103), comprise about 42 percent of the incised-punctated rims.

Table 7. Decorative elements on incised-punctated rim sherds.

\begin{tabular}{|c|c|c|}
\hline Decorative element & No. & Percent \\
\hline circular punctated row under lip-diagonal incised lines & 2 & 4.7 \\
\hline tool punctated row under lip-curvilinear incised line & 1 & 2.3 \\
\hline tool punctated row under lip-diagonal incised lines & 1 & 2.3 \\
\hline tool punctated row under lip-horizontal incised lines & 3 & 7.0 \\
\hline $\begin{array}{l}\text { tool punctated row or rows under lip and in horizontal } \\
\text { incised panel }\end{array}$ & 12 & 27.9 \\
\hline $\begin{array}{l}\text { diagonal incised line below tool punctated row under lip } \\
\text { and above mid-rim of tool punctates; second panel of } \\
\text { diagonal incised lines below, pitched in opposite } \\
\text { direction (see Figure 9j) }\end{array}$ & 1 & 2.3 \\
\hline $\begin{array}{l}\text { diagonal opposed incised lines above tool punctated } \\
\text { row at rim-body juncture and below tool punctated } \\
\text { row under lip (see Figure 9e) }\end{array}$ & 1 & 2.3 \\
\hline $\begin{array}{l}\text { diagonal incised lines above tool punctated row at } \\
\text { rim-body juncture }\end{array}$ & 1 & 2.3 \\
\hline $\begin{array}{l}\text { horizontal incised lines above tool punctated row at } \\
\text { rim-body juncture }\end{array}$ & 1 & 2.3 \\
\hline horizontal incised line above tool punctated row & 1 & 2.3 \\
\hline horizontal incised line above tool punctated rows & 1 & 2.3 \\
\hline
\end{tabular}

(see Figure 9i) 
Table 7. Decorative elements on incised-punctated rim sherds, cont.

\begin{tabular}{|c|c|c|}
\hline Decorative element & No. & Percent \\
\hline $\begin{array}{l}\text { horizontal and curvilinear incised zones filled with } \\
\text { tool punctates (see Figure } 9 \mathrm{~g} \text { ) }\end{array}$ & 1 & 2.3 \\
\hline $\begin{array}{l}\text { incised circular zones filled with tool punctates } \\
\text { (see Figure } 9 \mathrm{~b}, \mathrm{~h} \text { ) }\end{array}$ & 2 & 4.7 \\
\hline $\begin{array}{l}\text { incised triangles filled with tool punctates } \\
\text { (see Figure } 9 \mathrm{c}-\mathrm{d}, \mathrm{f})\end{array}$ & 13 & 30.2 \\
\hline $\begin{array}{l}\text { incised triangle panels filled with tool punctates } \\
\text { (see Figure 9a) }\end{array}$ & 1 & 2.3 \\
\hline rectilinear incised zone filled with tool punctates & 1 & 2.3 \\
\hline Totals & 43 & 100.0 \\
\hline
\end{tabular}

About 9 percent of the incised-punctated rims have circular or curvilinear incised elements, while the remainder have straight line elements. The punctated elements on these rim are almost uniformly made from tools, not fingernails or circular punctations. One of the incised-punctated jars has a rim peak (see Figure 9 h).

Many of the incised-punctated body sherds (66.7 percent) simply have a row or zone of punctations adjacent to curvilinear, diagonal, parallel, or straight incised lines (Table 8), but the decorative element is not discernable. The remainder have narrow incised bands or zones filled with punctations (5.4 percent); incised lines with circular or tool punctates pushed through the lines (1.8 percent); body sherds from Pease Brushed-Incised vessels with panels of incised lines pitched in various directions that are divided by a tool punctated row ( 6.1 percent); circular elements filled with punctates ( 1.8 percent); curvilinear lines and zones filled with punctates (3.0 percent); and a triangular-shaped punctated element and opposed incised lines ( 0.6 percent). The most common of the incised-punctated body sherds in the Musgano site ceramic assemblage have sets of incised triangles on Maydelle Incised vessels filled with punctates (14.0 percent) (Table 8$)$.

Table 8. Decorative elements on incised-punctated body sherds.

\begin{tabular}{lcc}
\hline Decorative element & No. & Percent \\
\hline $\begin{array}{l}\text { incised band with circular punctations } \\
\text { incised bands/zones with linear tool punctates (Figure 10r) } \\
\text { incised bands/zones with tool punctations (Figure 10v) }\end{array}$ & 3 & 1.8 \\
& 1 & 0.6 \\
$\begin{array}{l}\text { diagonal and horizontal incised lines with circular } \\
\text { punctates through them (Figure 10t) }\end{array}$ & 5.0 \\
$\begin{array}{l}\text { parallel incised lines with tool punctates through them } \\
\text { straight incised line with tool punctated row through it }\end{array}$ & 0.6 \\
$\begin{array}{l}\text { circular punctated zone adjacent to curvilinear incised line } \\
\text { circular punctated zone adjacent to parallel incised lines } \\
\text { circular punctated zone adjacent to straight incised line }\end{array}$ & 1 & 0.6 \\
& & 0.6
\end{tabular}




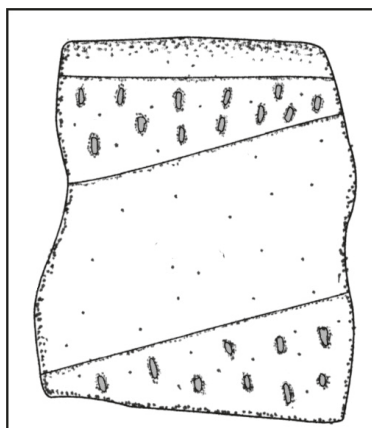

a
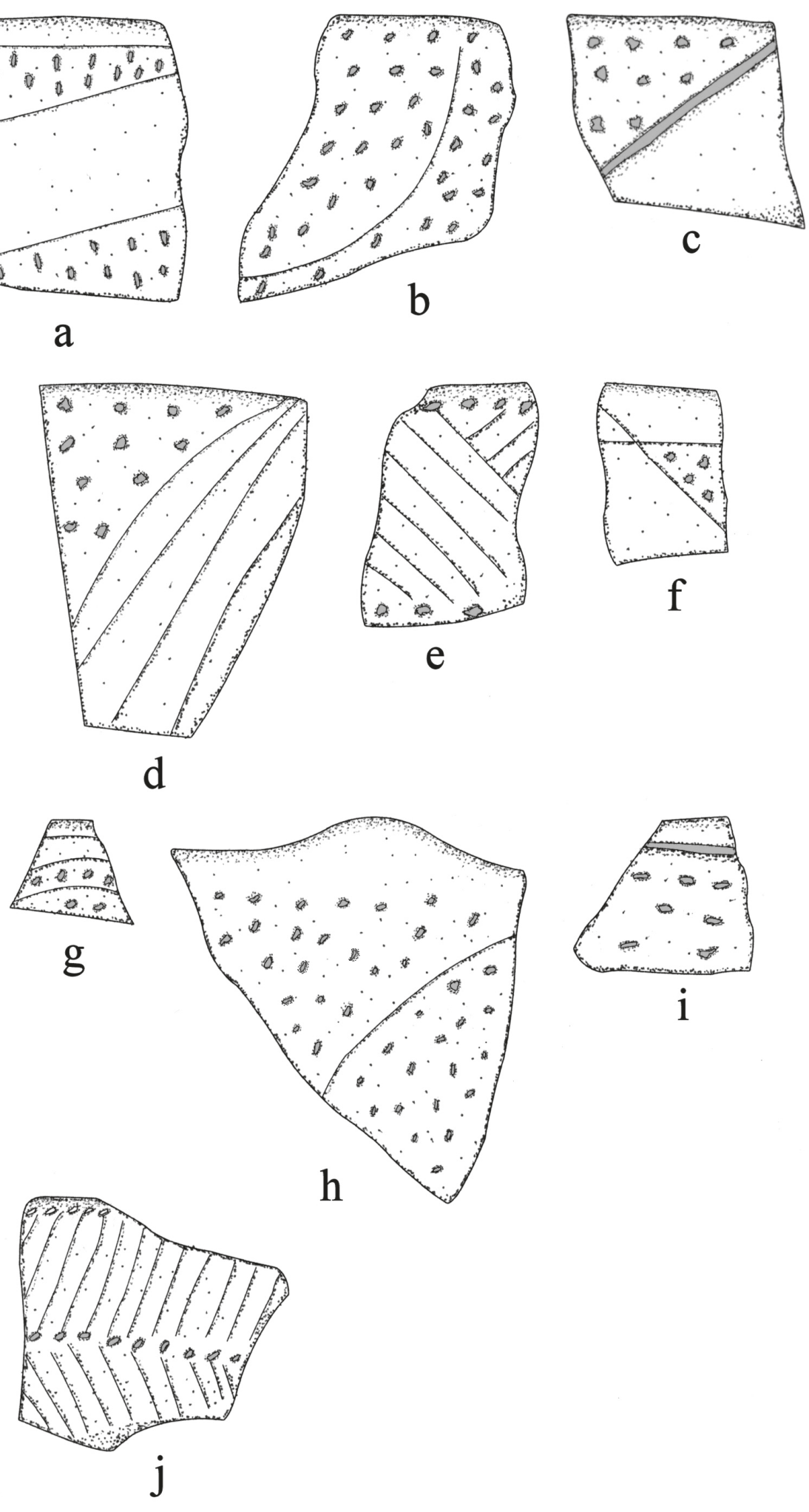

$\mathrm{h}$

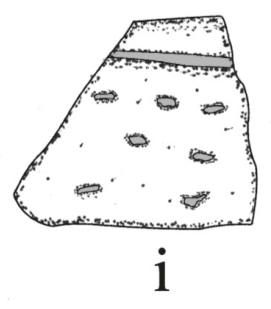

Figure 9. Incised-punctated elements on rim sherds. Note the rim peak of Figure 9h. Figure 9e is petrographic sample RK19-18. 
Table 8. Decorative elements on incised-punctated body sherds, cont.

\begin{tabular}{|c|c|c|}
\hline Decorative element & No. & Percent \\
\hline tool punctated zone adjacent to curvilinear incised line & 1 & 0.6 \\
\hline tool punctated row adjacent to diagonal incised lines (Figure 10k) & 4 & 2.4 \\
\hline tool punctated row adjacent to parallel incised lines & 5 & 3.0 \\
\hline tool punctated zone adjacent to parallel incised lines & 5 & 3.0 \\
\hline curvilinear tool punctated row adjacent to straight incised line & 1 & 0.6 \\
\hline tool punctated row adjacent to straight incised line & 25 & 15.2 \\
\hline tool punctated rows adjacent to straight incised line & 52 & 31.7 \\
\hline $\begin{array}{l}\text { tool punctated row between panels with diagonal } \\
\text { incised lines pitched in opposite directions (Figure } \\
\text { 10d-e, g-h, } \mathrm{u} \text { ) }\end{array}$ & 8 & 4.9 \\
\hline $\begin{array}{l}\text { tool punctated row between panels with diagonal } \\
\text { incised lines in same direction }\end{array}$ & 1 & 0.6 \\
\hline $\begin{array}{l}\text { tool punctated row between panels with diagonal and } \\
\text { horizontal lines (Figure 10s) }\end{array}$ & 1 & 0.6 \\
\hline circular element/zone filled with circular punctations & 2 & 1.2 \\
\hline circular element/zone filled with tool punctations & 1 & 0.6 \\
\hline curvilinear incised zone filled with circular punctates (Figure 10k) & 2 & 1.2 \\
\hline $\begin{array}{l}\text { curvilinear line and incised circle filled with tool } \\
\text { punctates (Figure 10b) }\end{array}$ & 1 & 0.6 \\
\hline $\begin{array}{l}\text { curvilinear incised lines and oval and rectilinear panels } \\
\text { filled with tool punctates (Figure 10a) }\end{array}$ & 2 & 1.2 \\
\hline $\begin{array}{l}\text { incised triangle elements filled with tool punctates } \\
(\text { see Figure } 10 \mathrm{c}, \mathrm{j}, \mathrm{m}-\mathrm{p})^{*}\end{array}$ & 22 & 13.4 \\
\hline incised triangle elements filled with circular punctates (Figure 10q) & 1 & 0.6 \\
\hline $\begin{array}{l}\text { triangular punctated element and opposed incised } \\
\text { lines (Figure 10i) }\end{array}$ & 1 & 0.6 \\
\hline Totals & 164 & 100.0 \\
\hline
\end{tabular}

*including one sherd from the rim panel of a carinated bowl

In general, the body sherds from vessels with incised-punctated decorations tend to have incised elements of various shapes (i.e., circles, horizontal bands, curvilinear zones, and triangles) that are filled primarily with tool punctations ( 80 percent of the zoned incised-punctated sherds). The remaining 20 percent of the zoned incised-punctated sherds are filled with circular punctates.

There are two Weches Fingernail Impressed rim and body sherds in the ceramic assemblage from the Musgano site. This includes a var. Weches sherd $(\mathrm{n}=1)$ that has crescent-shaped punctations between, or over horizontally incised lines (see Figure 10f) as well as a var. Alto sherd $(\mathrm{n}=1)$ with unzoned rows of crescent-shaped fingernail impressions (see Figure 12a, below) (e.g., Stokes and Woodring 1981:184-185). 

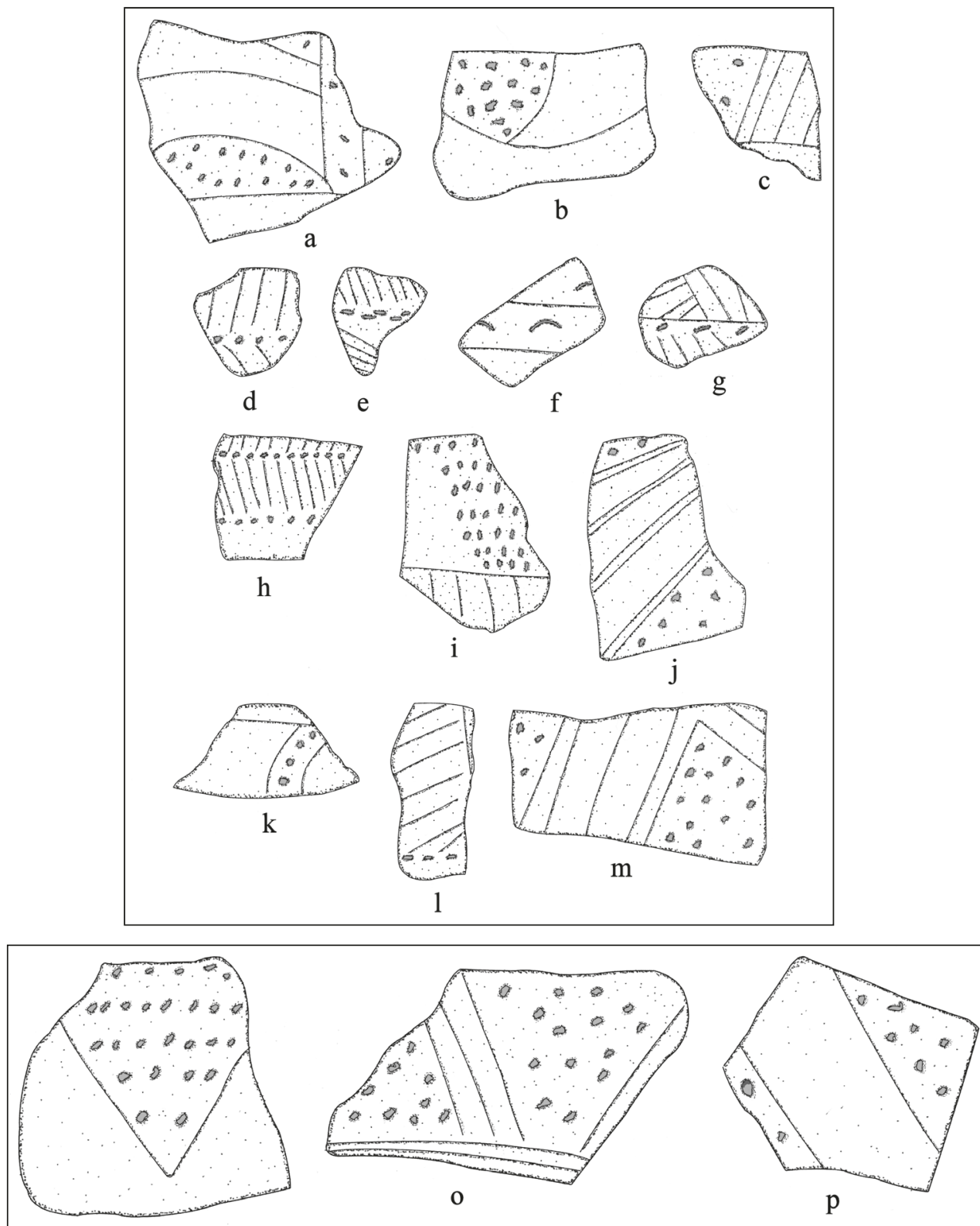

n
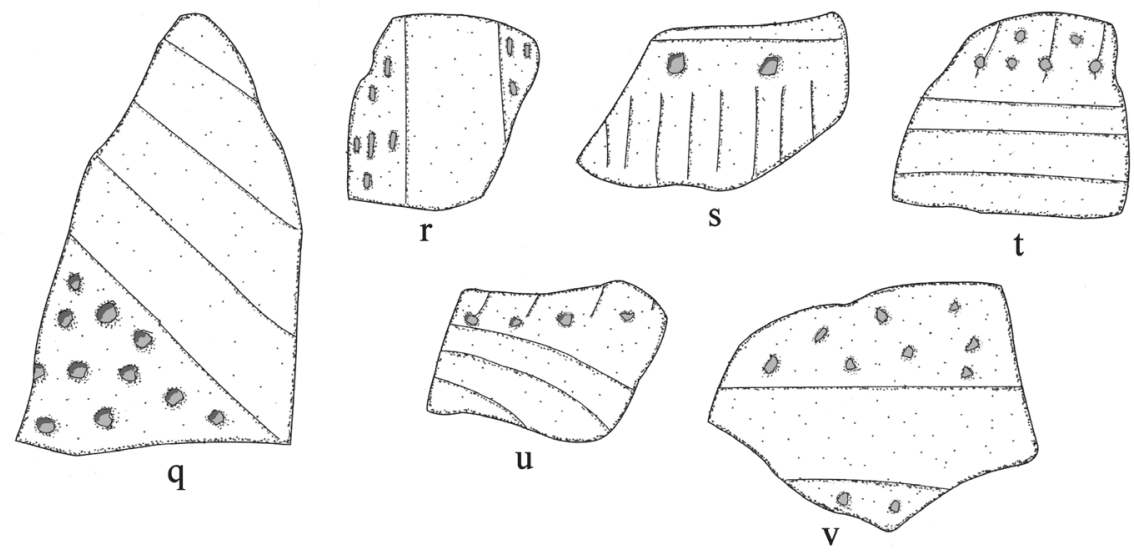

Figure 10. Incised-punctated elements on body sherds. Figure 10f is petrographic sample RK19-7; Figure 10h is petrographic sample RK19-11; Figure 10j is petrographic sample RK19-14; Figure 10n is petrographic sample RK19-20. 


\section{Washington Square Paneled}

Several $(n=8)$ of the incised-punctated sherds from the Musgano site are from Washington Square Paneled vessels (Figure 11a-h). The rim panels of these carinated bowls have horizontal interlocking incised scrolls with upper, lower, and vertical incised bands filled with tool punctates. This particular decorative style on the rims from these vessels has a considerable distribution on Middle Caddo (ca. A.D. 1200-1450) period sites in the mid-Sabine River basin and tributaries (Gadus et al.2006; Perttula and Nelson 2013; Perttula et al. 2014a; Walters 2008) as well as contemporaneous Caddo sites in the Angelina River basin (see Hart 1982, 2014; Perttula 2008; Perttula et al. 2010).

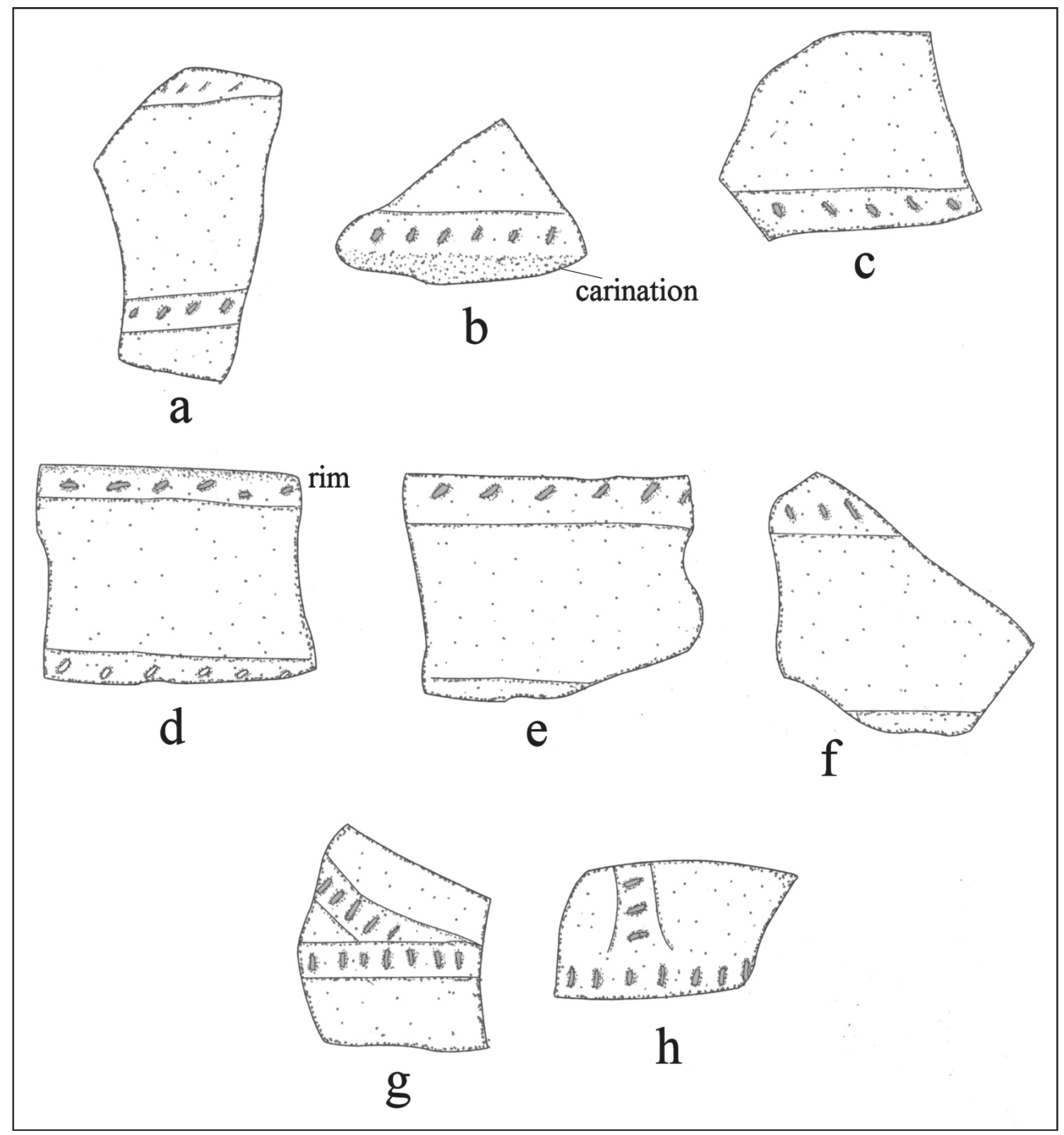

Figure 11. Washington Square Paneled rim and body sherds. Figure 11d is petrographic sample RK19-17. 


\section{Pinched}

The pinched sherds ( $\mathrm{n}=29,1.4$ percent of the decorated sherd assemblage) are from Killough Pinched jars (Suhm and Jelks 1962:91 and Plate 46). These jars typically have pinched decorations that cover the entire exterior vessel surface. In the Musgano site ceramic assemblage, the one rim (with a rounded and exterior folded lip) sherd has a horizontal row of pinched impressions. Body sherds have concentric circle $(n=1)$, curvilinear $(n=2)$, parallel $(n=24)$, and straight $(n=1)$ rows of pinched impressions.

\section{Punctated}

Sherds with punctated decorative elements are second in abundance in the Musgano site utility wares, comprising 20.3 percent of all the utility wares and 38 percent of the utility ware rim sherds (see Table 4). Decorative elements on the rim are primarily one or multiple horizontal rows of punctates - mainly tool punctates, but circular punctated elements are also common - although two lower rims have diagonal rows of punctates as well as a horizontal row along the rim-body juncture (on a jar) or above a vessel carination on a carinated bowl (Table 9 and Figure 12b-c). One pre-A.D. 1300 Weches Fingernail Impressed, var. Alto rim sherd with crescent-shaped punctations is in the assemblage of punctated utility wares (Figure 12a).

Table 9. Decorative elements on punctated rim sherds.

\begin{tabular}{lcc}
\hline Decorative element & No. & Percent \\
\hline $\begin{array}{l}\text { diagonal rows of fingernail punctations } \\
\text { diagonal rows of tool punctations }\end{array}$ & 1 & 1.7 \\
$\begin{array}{l}\text { horizontal rows of circular punctations } \\
\text { horizontal rows of fingernail punctations } \\
\text { horizontal rows of tool punctations } \\
\text { horizontal row of tool punctations under lip }\end{array}$ & 3 & 5.2 \\
horizontal rows of crescent-shaped fingernail punctations, & 10 & 17.2 \\
Weches Fingernail Impressed, var. Alto & 30 & 6.9 \\
\hline Totals & 9 & 15.5 \\
\hline
\end{tabular}

Body sherds from utility ware vessels with punctated decorative elements have punctates made from square or triangular-shaped wood tools ( $\mathrm{n}=237,71.6$ percent), tools with a small circular end ( $\mathrm{n}=33,10$ percent), cane tools ( $\mathrm{n}=4,1.2$ percent), and punctates made from impressed fingernails $(\mathrm{n}=57,17.2$ percent). These punctates occur in rows and/or zones across the vessel body of the utility wares.

\section{Stamped}

The stamped body sherd is from the rim panel of a carinated bowl. It has at least two closely-spaced horizontal rows of stamping on the rim panel, perhaps in a narrow zone. It is suspected that this vessel is of non-local manufacture, perhaps a vessel made by a Caddo potter in the Ouachita River basin in southwestern Arkansas (see Perttula 2011:228). 


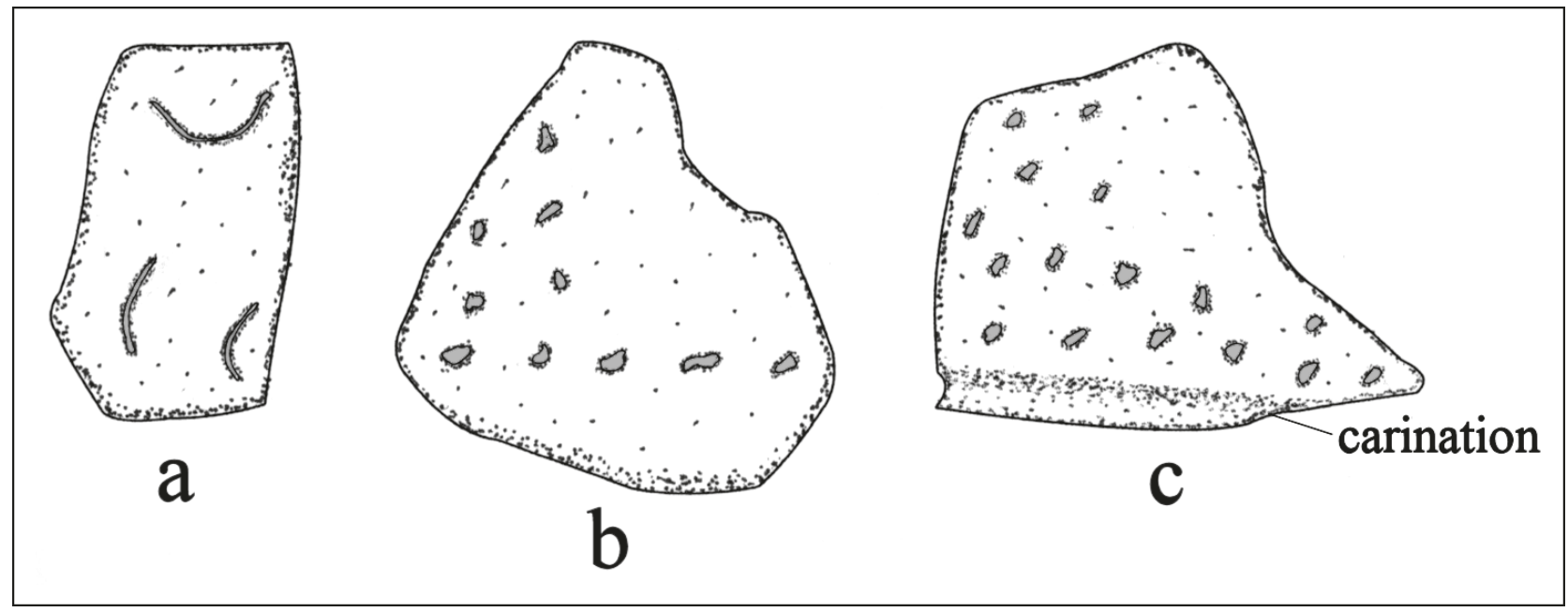

Figure 12. Punctated elements on rim sherds.

\section{Fine Ware Sherds}

Only 8.7 percent of the decorated sherds from the Musgano site are from fine wares (see Table 4). This includes engraved $(n=180)$ and red-slipped $(n=3)$ sherds. Vessels with engraved decorations include bottles with engraved elements on the body as well as an occasional bottle neck and bowls and carinated bowls with decorations confined to the upper part of the bowl and the rim panel on carinated bowls.

\section{Engraved carinated bowl and bowl sherds}

The rims from engraved carinated bowls and bowls in the Musgano assemblage feature circular and curvilinear elements, sets of diagonal lines, and rims with horizontal lines and various associated elements (Table 10). These include curvilinear and diagonal lines, zig-zag lines, excised punctations, hatched pendant triangles, cross-hatched zones (possibly triangular elements), and hatched oval-shaped elements (Figure 13a-i). The rims with horizontal engraved lines and associated elements comprise 72.9 percent of the engraved rims from carinated bowls and bowls. None of the rims have scroll elements, which feature so prominently in post-ca. A.D. 1450 assemblages in the mid-Sabine River basin (e.g., Fields and Gadus 2012). Furthermore, none of the engraved rims from the Musgano site can be identified with a currently defined fine ware type in the East Texas ceramic typology (although the Washington Square Paneled sherds may be a fine ware type, even though they have incised-punctated decorative elements in this assemblage), which is a common situation for Middle Caddo period fine wares in this part of East Texas because of the stylistic diversity that is characteristic of these ca. A.D. 1200-1450 ceramic assemblages.

Table 10. Decorative elements on engraved rim sherds.

\begin{tabular}{lcc}
\hline Decorative element & No. & Percent \\
\hline circular element & 1 & 4.5 \\
circle elements with pendant hatched triangles (see & 1 & 4.5 \\
$\quad \begin{array}{l}\text { Figure 13e) } \\
\text { concentric curvilinear lines }\end{array}$ & 1 & 4.5
\end{tabular}


Table 10. Decorative elements on engraved rim sherds, cont.

\begin{tabular}{|c|c|c|}
\hline Decorative element & No. & Percent \\
\hline curvilinear line & 1 & 4.5 \\
\hline diagonal lines & 2 & 9.1 \\
\hline horizontal lines & 3 & 13.6 \\
\hline $\begin{array}{l}\text { horizontal, concentric curvilinear, and diagonal lines } \\
\text { (see Figure } 13 \mathrm{~g}, \mathrm{i} \text { ) }\end{array}$ & 2 & 9.1 \\
\hline $\begin{array}{l}\text { horizontal lines and curvilinear lines } \\
\text { (see Figure 13d) }\end{array}$ & 1 & 4.5 \\
\hline $\begin{array}{l}\text { horizontal and diagonal lines } \\
\text { (see Figure 13h) }\end{array}$ & 3 & 13.6 \\
\hline $\begin{array}{l}\text { horizontal line and diagonal zig-zag lines } \\
\text { (see Figure 13b) }\end{array}$ & 1 & 4.5 \\
\hline horizontal line and pendant cross-hatched zone & 2 & 9.1 \\
\hline $\begin{array}{l}\text { horizontal line and hatched pendant triangle } \\
\text { (see Figure 13f) }\end{array}$ & 1 & 4.5 \\
\hline $\begin{array}{l}\text { horizontal and vertical lines and hatched pendant triangle } \\
\text { (see Figure 13c) }\end{array}$ & 1 & 4.5 \\
\hline $\begin{array}{l}\text { horizontal panel with hatched oval-shaped element } \\
\text { (see Figure 13a) }\end{array}$ & 1 & 4.5 \\
\hline horizontal panel with excised punctations & 1 & 4.5 \\
\hline Totals & 22 & 100.0 \\
\hline
\end{tabular}

The one rim with a hatched oval-shaped element (see Figure 13a) is quite distinctive. Very similar decorative elements have been reported from several sites in the upper and mid-Sabine River basin, although these sites appear to have been occupied after ca. A.D. 1450. This includes two carinated bowls in the Gregg County Historical Museum East Texas Caddo vessel collection that have the same oval-shaped engraved eye element, as well as an engraved olla from the Quitman area in the upper Sabine River basin (Perttula and Wright 2014). One of the former is a Ripley Engraved carinated bowl with engraved ovals with excised eye elements, and adjacent engraved triangle elements with negative ovals (Perttula et al. 2014b:Figure 33d), and the other is a carinated bowl with oval eye-shaped engraved elements below a series of horizontal engraved lines around the rim (Perttula et al. 2014b:Figure 79d). Another Caddo vessel with an engraved eye element is on a carinated bowl from the $18^{\text {th }}$ century Kinsloe phase Millsey Williamson site (41RK3) in the mid-Sabine River basin (see Perttula and Nelson 2014). The rim panel on this vessel has sets of opposed engraved oval eye motif repeated four times around the vessel; the oval eyes are connected by a rectangular excised element. The sets of eye elements are separated by nested triangles with negative ovals and hooked arm elements (Perttula and Nelson 2014:Figures 4 and 5a). Middlebrook (December 2013 personal communication) reports that two bowls with rim peaks from 41SY41 in the Angelina River basin in East Texas also have oval eye-shaped elements, but these ovals point downwards on the vessels.

The rim with a zig-zag engraved element is from a vessel with a rim peak (see Figure 13b). Newell and Krieger (1949:96) and Stokes and Woodring (1981:Figure 20j) have identified similar zig-zag 


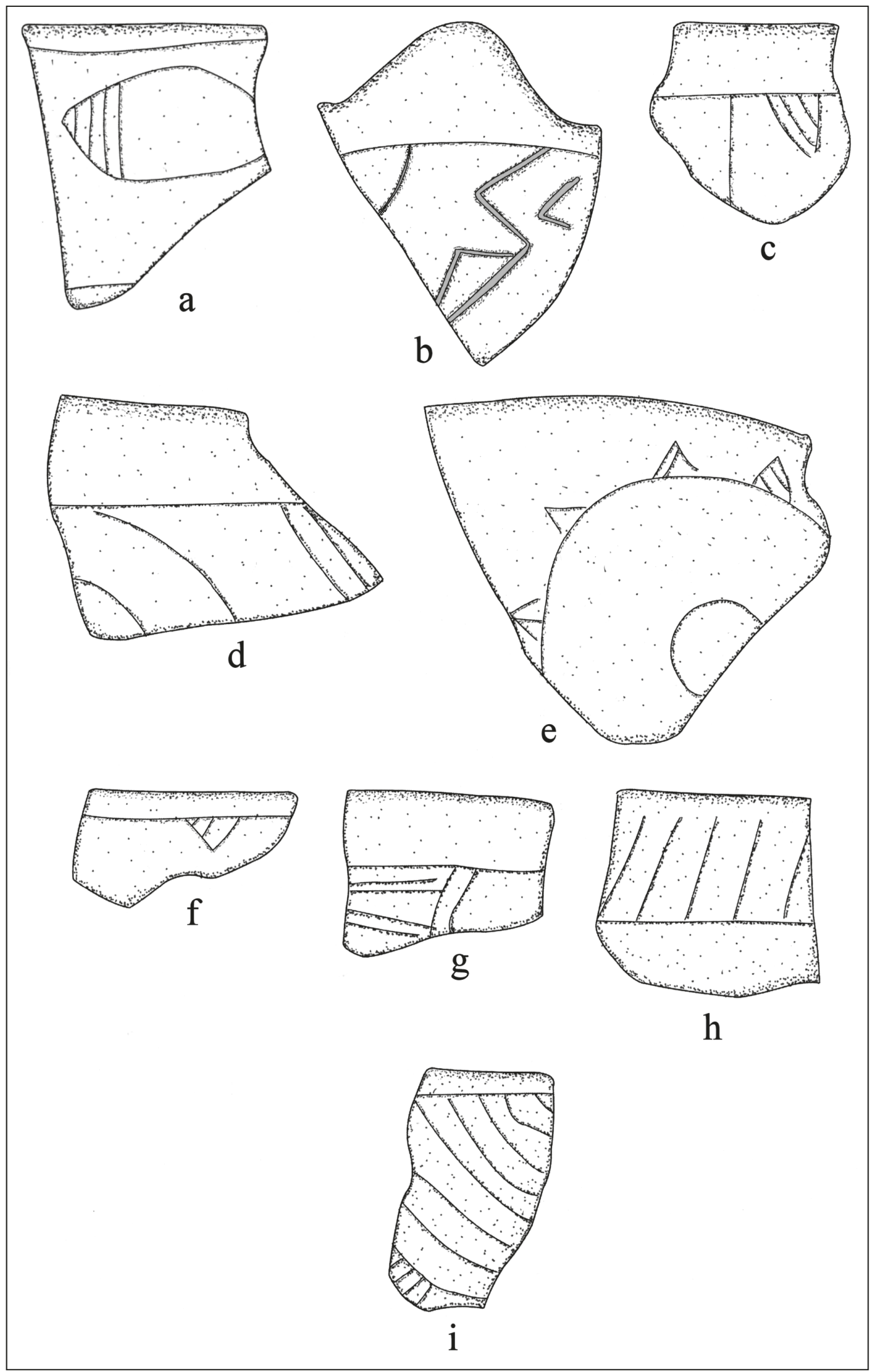

Figure 13. Engraved elements on bowl and carinated bowl rim sherds. 
engraved sherds from mound and village contexts at the George C. Davis site in pre-A.D. 1300 contexts. The other rims are from carinated bowls (see Figure 13a, c-d, f-i) and bowls (see Figure 13e) that have direct or vertical rim profiles and rounded lips.

The decorative elements on the engraved carinated bowl and bowl sherds from the Musgano site are as diverse as the recognizable elements on the rims (Table 11 and Figure 14a-p); none of the sherds are part of a scroll motif. The more recognizable and distinctive elements include circles and hatched circles, narrow hatched and cross-hatched zones and cross-hatched triangles (10.7 percent of the engraved body sherds), curvilinear hatched and cross-hatched zones as well as hatched pendant triangles (7.2 percent), horizontal engraved lines with hatched and cross-hatched pendant triangles (5.3 percent), and sets and arcs of curvilinear lines (15.9 percent).

Table 11. Decorative elements on engraved carinated bowl and bowl body sherds from the Musgano site.

\begin{tabular}{|c|c|c|}
\hline Decorative element & No. & Percent \\
\hline circle element (see Figure 14k) & 1 & 0.9 \\
\hline cross-hatched engraved zone & 9 & 8.0 \\
\hline cross-hatched zone, triangular element & 2 & 1.8 \\
\hline curvilinear lines & 17 & 15.0 \\
\hline curvilinear arcing lines (see Figure 14m) & 1 & 0.9 \\
\hline curvilinear cross-hatched zone (see Figure 14a) & 2 & 1.8 \\
\hline curvilinear hatched zone (see Figure $14 \mathrm{j}$ ) & 3 & 2.7 \\
\hline curvilinear lines and hatched pendant triangles (see Figure 14p) & 2 & 1.8 \\
\hline curvilinear hatched and cross-hatched zones & 1 & 0.9 \\
\hline curvilinear and opposed straight lines (see Figure 14i) & 2 & 1.8 \\
\hline hatched circle element & 2 & 1.8 \\
\hline hatched zone, narrow & 1 & 0.9 \\
\hline horizontal lines & 1 & 0.9 \\
\hline $\begin{array}{l}\text { horizontal lines and cross-hatched zone } \\
\text { (see Figure 14o) }\end{array}$ & 1 & 0.9 \\
\hline $\begin{array}{l}\text { horizontal line and panels with concentric circles } \\
\text { (see Figure } 14 \mathrm{~g}, 1)\end{array}$ & 2 & 1.8 \\
\hline horizontal and curvilinear arcing lines (see Figure 14e) & 4 & 3.5 \\
\hline horizontal line and hatched pendant triangle (see Figure $14 \mathrm{~h}$ ) & 5 & 4.4 \\
\hline horizontal line and cross-hatched pendant triangle & 1 & 0.9 \\
\hline $\begin{array}{l}\text { horizontal lines and panels with nested triangles and } \\
\text { rectangles (see Figure 14d) }\end{array}$ & 1 & 0.9 \\
\hline $\begin{array}{l}\text { horizontal and vertical lines and nested curvilinear lines } \\
\text { (see Figure } 14 \mathrm{f}, \mathrm{n} \text { ) }\end{array}$ & 2 & 1.8 \\
\hline opposed lines & 10 & 8.8 \\
\hline parallel lines & 14 & 12.4 \\
\hline
\end{tabular}


Table 11. Decorative elements on engraved carinated bowl and bowl body sherds from the Musgano site, cont.

\begin{tabular}{lcc}
\hline Decorative element & No. & Percent \\
\hline parallel lines and excised pendant triangle & 2 & 1.8 \\
parallel and curvilinear lines (see Figure 14c) & 1 & 0.9 \\
parallel lines and hatched zone (see Figure 14b) & 2 & 1.8 \\
single straight line & 24 & 21.2 \\
\hline Totals & 113 & 100.0 \\
\hline
\end{tabular}

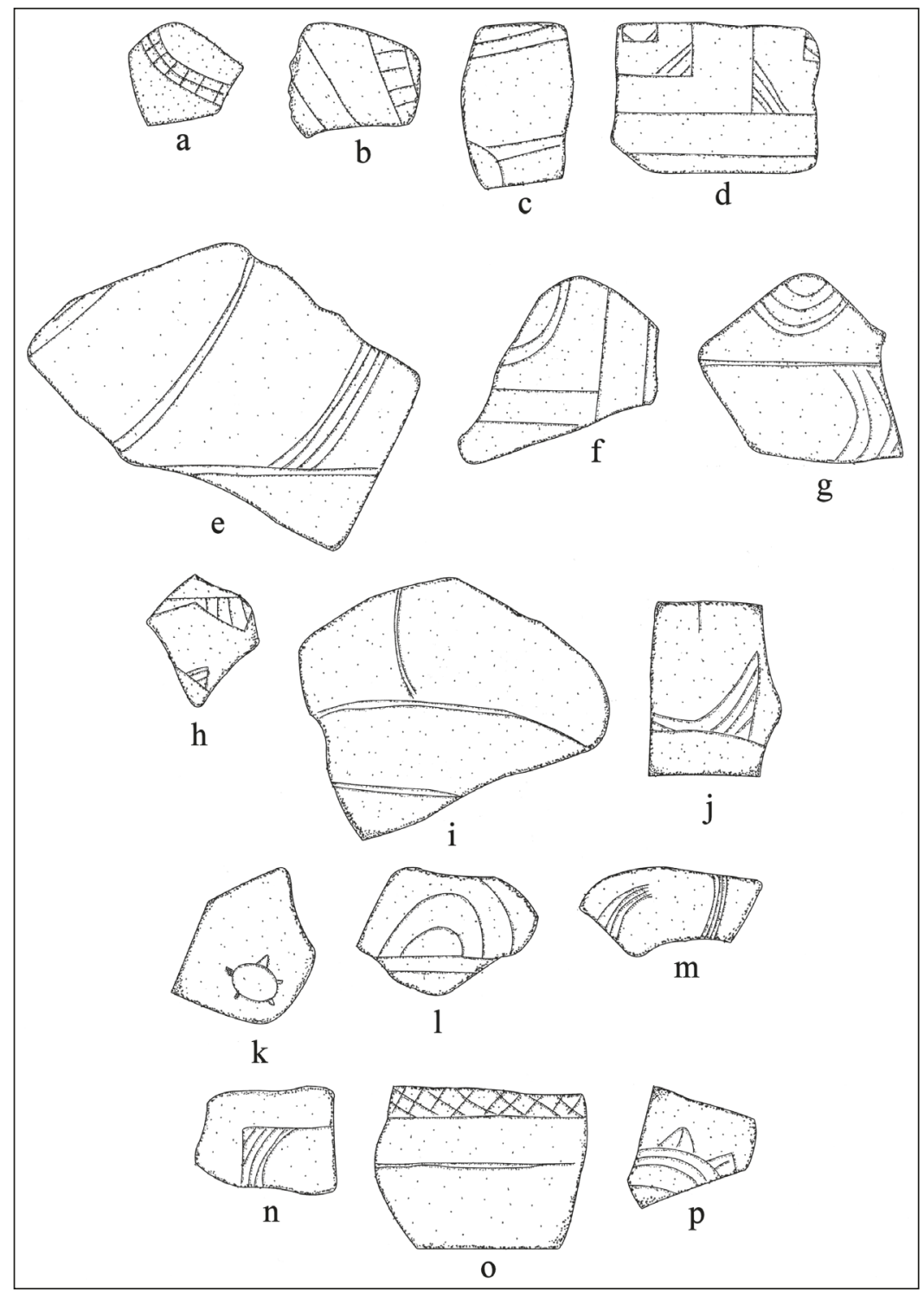

Figure 14. Engraved elements on carinated bowl body sherds. Figure 14f is petrographic sample RK19-13; Figure 14g is petrographic sample RK19-16; and Figure 14j is petrographic sample RK19-19. 
It is noteworthy that many of the same engraved elements are present in the nearby and generally contemporaneous Oak Hill Village (41RK214) ceramic assemblage (Rogers and Perttula 2004:217-222) as well as other mid-Sabine River basin sites. Most notably, these include: (a) closely-spaced curvilinear lines; (b) hatched and cross-hatched triangle elements; (c) narrow hatched and cross-hatched zones or ladders (the most common engraved decorative element at the Oak Hill Village); and (d) circle elements and concentric circles with pendant triangles.

\section{Engraved bottle sherds}

Engraved bottle sherds comprise 23.9 percent of the engraved fine wares from the Musgano site. The one engraved bottle rim sherd is from a Hickory Engraved bottle that has a series of horizontal lines encircling the neck (cf. Suhm and Jelks 1962:71). The other engraved bottle sherds are from the vessel bodies. The decorative elements on the bottle bodies are diverse (Figure 15a-q), with circles, hatched and cross-hatched ovals and narrow panels and zones, as well as possible canebrake rattlesnake elements from Nacogdoches Engraved vessels (Figure 15l-m); two body sherds have a red clay pigment rubbed in the engraved lines (Figure 15n). Specifically, the engraved bottle body sherds $(n=40)$ have:

- $\quad$ straight lines $(\mathrm{n}=1)$,

- $\quad$ parallel lines $(n=1)$

- vertical lines and triangular elements $(n=1)$,

- curvilinear lines $(\mathrm{n}=8)$,

- curvilinear lines and hatched zones (n=3, Figure $15 \mathrm{c}, \mathrm{e})$,

- opposed straight and curvilinear lines ( $\mathrm{n}=4$, Figure $15 \mathrm{~g}$ ),

- opposed lines and a hatched pendant triangle element $(\mathrm{n}=1)$,

- hatched triangle elements ( $\mathrm{n}=4$, Figure $15 \mathrm{k}$ ),

- horizontal and curvilinear arcing lines around a circle element ( $\mathrm{n}=1$, Figure $15 \mathrm{a})$,

- horizontal and curvilinear lines and hatched and cross-hatched zones $(n=3$, Figure 15h-i, n),

- narrow cross-hatched zones ( $\mathrm{n}=5$, Figure $15 \mathrm{j}, \mathrm{o}-\mathrm{q})$,

- hatched zones and ovals ( $\mathrm{n}=3$, Figure $15 \mathrm{~b}, \mathrm{~d})$,

- horizontal and diagonal lines and pendant cross-hatched zones ( $n=3$, Figure 15f), and

- $\quad$ possible canebrake rattlesnake elements ( $n=2$, Figure $151-m)$

Engraved canebrake rattlesnake motifs on bottles has been found in ceramic assemblages in at least 17 Middle and Late Caddo period sites in the Big and Little Cypress Creek, mid-Sabine, Red River, and Angelina River basins in East Texas (Gadus 2013:221). The motif consists of "representational images of snakes with entwined or interlocking tails" (Gadus 2013:221). At the Musgano site, the first of the bottle sherds with possible canebrake rattlesnake elements is one with a head with lines and dots suggesting its eyes and nose (see Figure 15l). The other has a cross-hatched zone that may represent part of the body of the snake, along with part of what may be part of a curvilinear forked tongue (see Figure $15 \mathrm{~m}$ ).

\section{Holly Fine Engraved sherds}

Finally, there are two Holly Fine Engraved bottle sherds (grog and bone-tempered) in the fine wares from the Musgano site (Figure 16a-b). Their presence in the ceramic assemblage, along with the few Weches Fingernail Impressed sherds (see above), constitutes evidence of a limited pre-A.D. 1300 use (cf. Story 2000) of the site by Caddo peoples. 


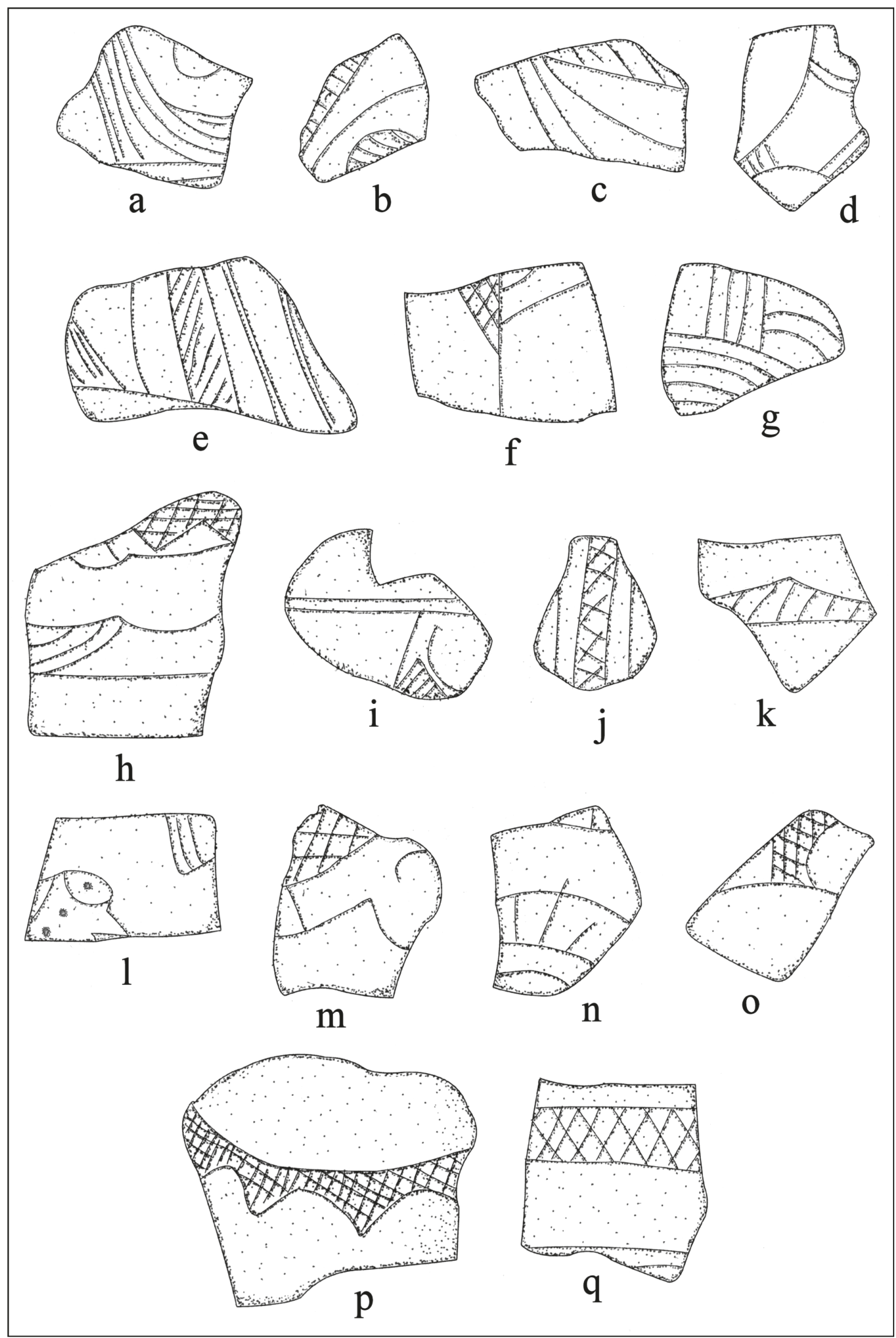

Figure 15. Engraved bottle sherds. Figure 15a is petrographic sample RK19-2 and Figure 15e is petrographic sample RK19-8. 


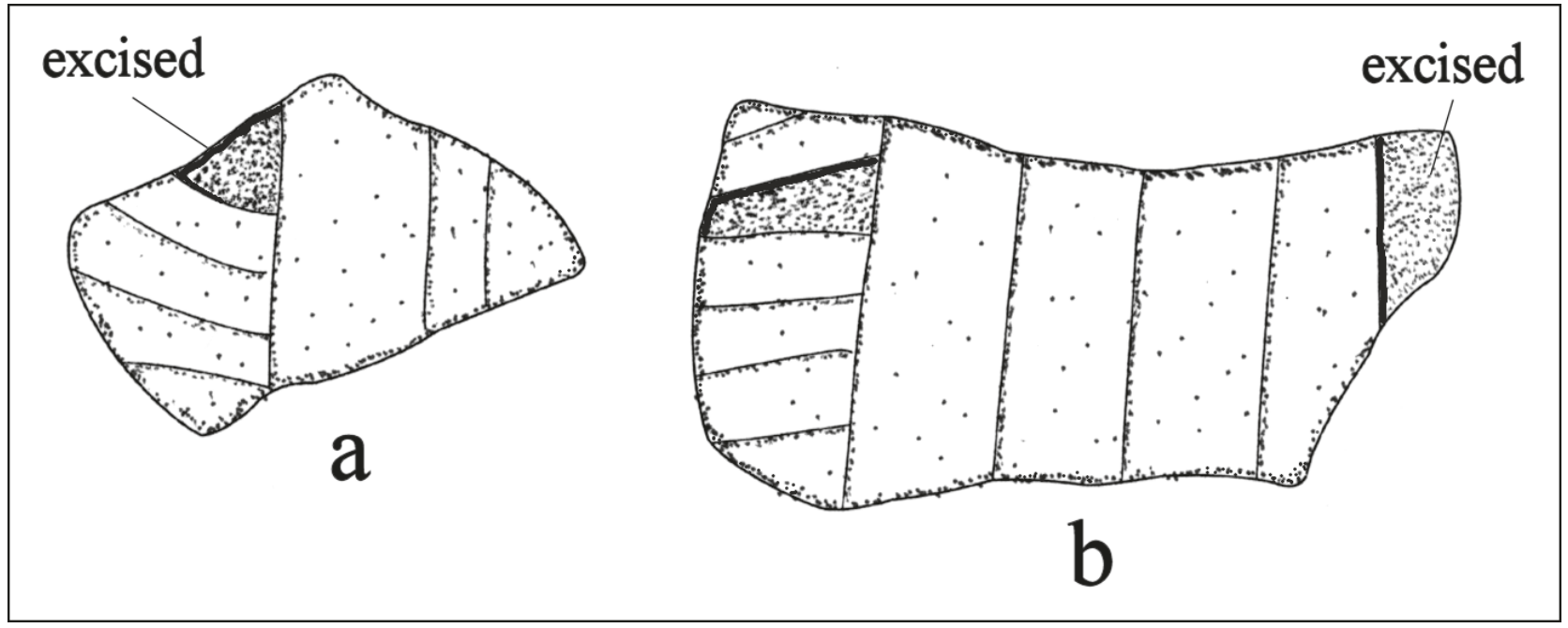

Figure 16. Holly Fine Engraved bottle sherds from the Musgano site.

\section{Red-slipped}

The three red-slipped fine ware sherds are from the bodies of bowls or carinated bowls. They are slipped only on the exterior surface of the vessels.

\section{Rim and Lip Form on Utility Wares and Fine Wares}

As with the plain rims in the assemblage, the decorated wares generally tend to have direct or vertical rim profiles: 82 percent of the utility ware rims $(n=127), 80$ percent of the Washington Square Paneled rims $(n=5)$, and 83 percent of the fine ware rims $(n=18)$. About 7 percent of the utility ware rims have an everted rim profile, but none of the other decorated wares did; 3 percent of the plain rims have everted rim profiles. Rim peaks are present on 1.3 percent of the decorated rim sherds, one utility ware rim $(0.8$ percent) and one fine ware rim (5.6 percent).

The great majority of the decorated rims have rounded lip profiles: 80 percent of the utility wares, 60 percent of the Washington Square Paneled rims, and 78 percent of the fine wares. Rounded and exterior folded lips are present on 9.5 percent of the utility wares, 40 percent of the Washington Square Paneled rims, and 5.6 percent of the fine wares; by comparison, 15.6 percent of the plain rims have an exterior folded lip. Flat lip profiles are represented in both the utility wares and fine wares, with 7.9 percent and 11.1 percent, respectively; 15.6 percent of the plain wares have flat lips. Flat and exterior folded lips occur only in the utility ware rims (1.6 percent). Finally, one fine ware rim (5.6 percent) has a rounded and exterior thickened lip and two utility ware rims (1.6 percent) have flat and exterior thickened lips.

\section{Regional Ceramic Comparisons}

There are a number of analyzed ceramic assemblages in the mid-Sabine River and upper Angelina River basins that represent distinctive Middle Caddo period ceramic traditions with similarities to the Musgano site assemblage (see Dockall et al. 2008; Dockall and Fields 2011; Gadus et al. 2006; Heartfield, Price, and Greene, Inc. 1988; Perttula 2001; Perttula and Nelson 2003; Rogers and Perttula 2004). Where radiocarbon dates have been obtained from archaeological deposits at these sites they indicate the Caddo assemblages date from ca. A.D. 1150 to ca. A.D. 1450, and perhaps a bit later at a few sites in the mid-Sabine River basin (i.e., 41HS573 and 41HS588, see Dockall et al. 2008; Gadus et al. 2006). 
In general, these ceramic assemblages are dominated by decorated utility wares, including vessels with incised, incised-punctated, and punctated decorative elements primarily from pre-A.D. 1300 contexts (Table 12), and then later the decorated utility wares in sites begin to be dominated by sherds from brushed vessels, leading to much lower percentages of other kinds of decorated utility wares as well as lower proportions of fine wares. Assemblages where sherds from brushed vessels comprise more than 40 percent of the decorated sherd assemblages are also those where fine wares account for less than 13 percent of the overall assemblages (Table 12); this group of assemblages also includes the Musgano site. Red-slipped sherds account for less than 1 percent of the decorated sherds in all these assemblages, and only 0.1 percent of the decorated sherd assemblage at the Musgano site.

Washington Square Paneled sherds are present in the Musgano site ceramic assemblage (see Figure 11) and other generally contemporaneous sites in the mid-Sabine River basin. This includes $41 \mathrm{HS} 573$ (Gadus et al. 2006:Figure 4-12), 41HS574 (Gadus et al. 2006:Figure 4-29), and 41HS718 (Gadus et al. 2006:Figures 4-40 and 4-43). Another distinctive fine ware decorative element found in these mid-Sabine River basin assemblages as well as at the Musgano site is the engraved rattlesnake motif. Sherds with this motif have been found at the Oak Hill Village (41RK214) (Rogers and Perttula 2004:Figures 91p and 92), 41RK242 (Perttula 2001), and 41HS74 (Heartfield, Price, and Greene, Inc. 1988:Figure 6-16).

Proportional trends in decorative elements, along with a series of calibrated radiocarbon dates and date ranges, also indicate that by ca. A.D. 1450 and after, mid-Sabine River basin sites have decorated sherd assemblages where more than 60 percent of all the decorated sherds have brushed decorative elements on rim and/or body sherds (Table 13). In the latest group of sites in these assemblages, between 65.8-66.7 percent of all the decorated sherds have brushed elements, either as the sole decorative element, or in association with appliqued, incised, or punctated elements. Ceramic assemblages that appear to predate A.D. 1450 fall into what are suggested to represent three temporally sequent assemblages with (1) between 42.9-51.2 percent brushed sherds (including the Musgano site); (2) 28.7-47.7 percent brushed sherds; and (3) 15.5-20.3 percent brushed sherds (Table 13). Sherds with brushed-incised and brushed-punctated decorative elements also appear to be most common in these pre-A.D. 1450 assemblages. The very low percentage of brushed sherds at the contemporaneous Nawi haia ina site (41RK170) in the upper Angelina River basin suggests that the ceramic assemblage there is part of a different Caddo ceramic tradition than the ceramic tradition in the mid-Sabine River basin Caddo sites.

\section{Ceramic Pipes}

Ceramic pipe sherds are relatively abundant in the archaeological deposits at the Musgano site. They include five sherds (one pipe bowl and four stem sherds) from long-stemmed Red River pipes, probably var. Haley (Hoffman 1967), 18 bowl and stem sherds from distinctive L-shaped elbow pipes, and portions of two squat L-shaped elbow pipes (Figure 17).

Other sites with L-shaped elbow pipes include Oak Hill Village (41RK214, Rogers and Perttula 2004), Lang Pasture (41AN38, Perttula 2011), Redwine (41SM193, Walters et al. 1998), Spoonbill (41WD109, Perttula et al. 2009), 41SM247 (Perttula et al. 2009), 41SM290 (Perttula et al. 2009), Pace McDonald (41AN51, Perttula et al. 2012:Figure 5), 41WD244 (Perttula et al. 2007), Joe Smith (41GG50, Perttula and Nelson 2013:Figure 35), Wade (in Gregg County, Perttula et al. 2014a), and Beech Ridge (41NA242, Perttula 2008). These sites, in the Sabine, Neches, and Angelina River basins, have Middle Caddo period occupations, which is when the distinctive L-shaped elbow pipes appear to have begun to be made by Caddo peoples in East Texas. An examination of the clay elbow pipes from mortuary contexts in the upper Neches River basin, from cemeteries of known age, indicates that the earliest elbow pipes (Var. A) are plain L-shaped forms, and are found in contexts estimated to date from ca. A.D. 1320-1450. 


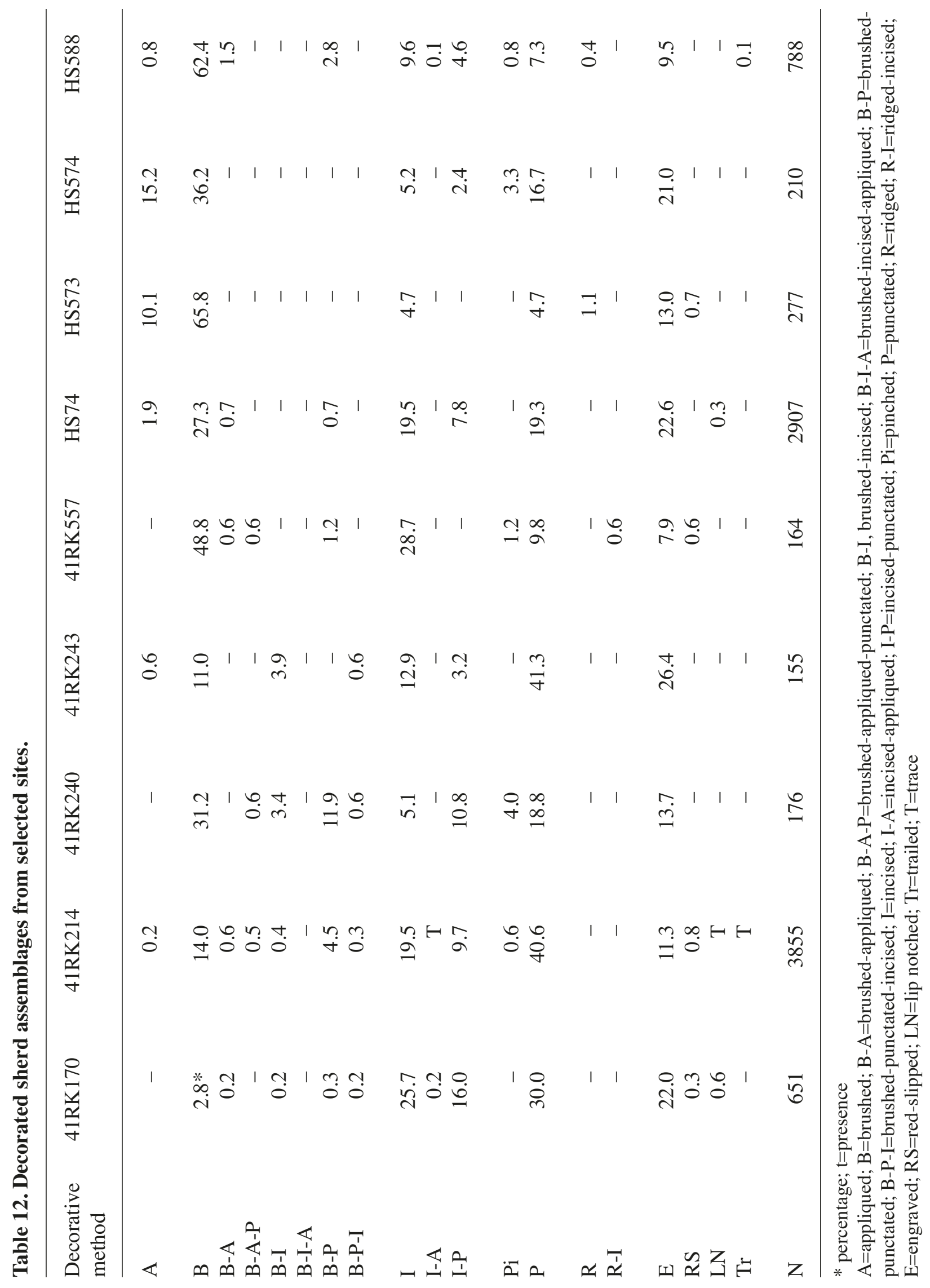




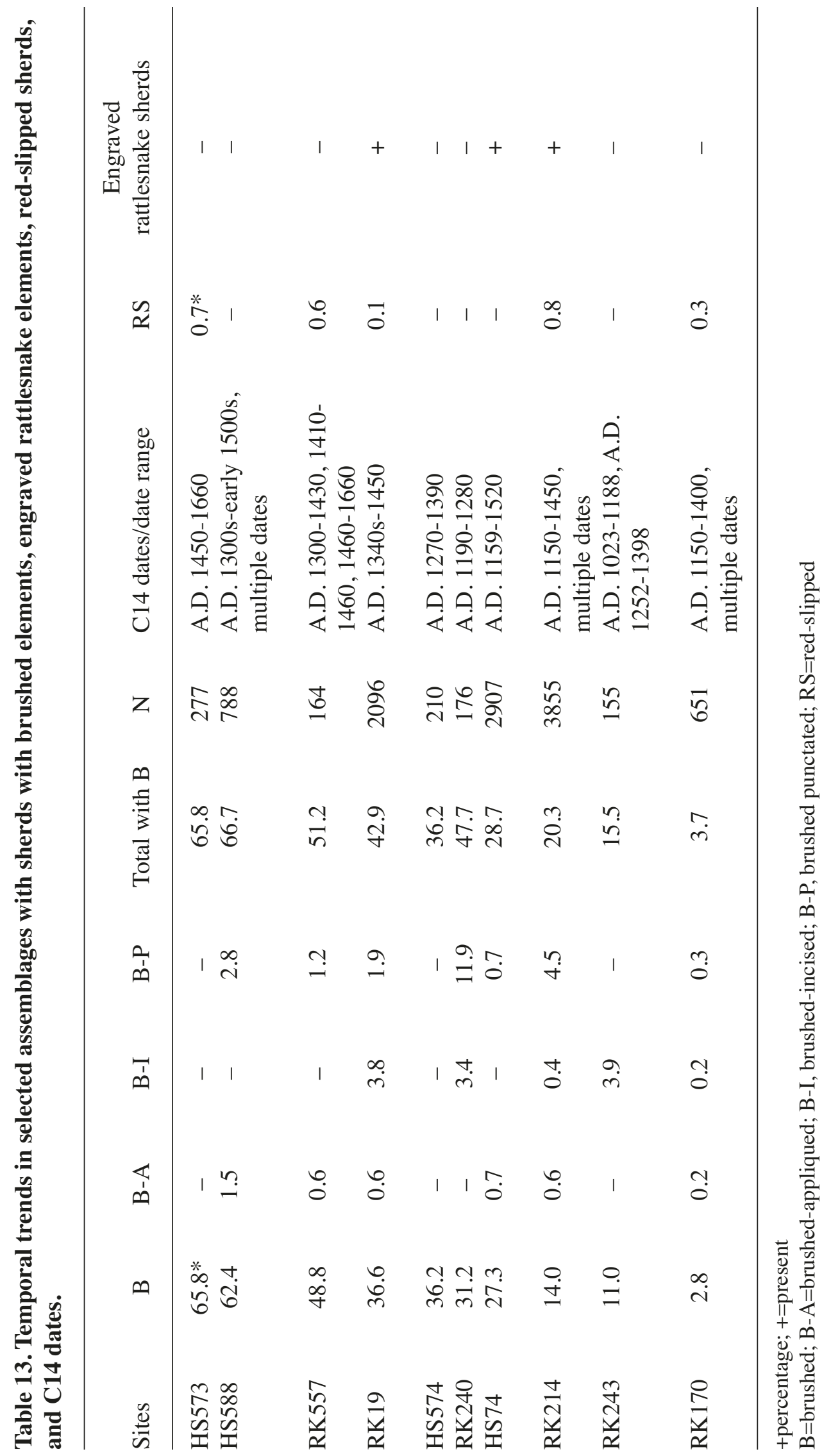




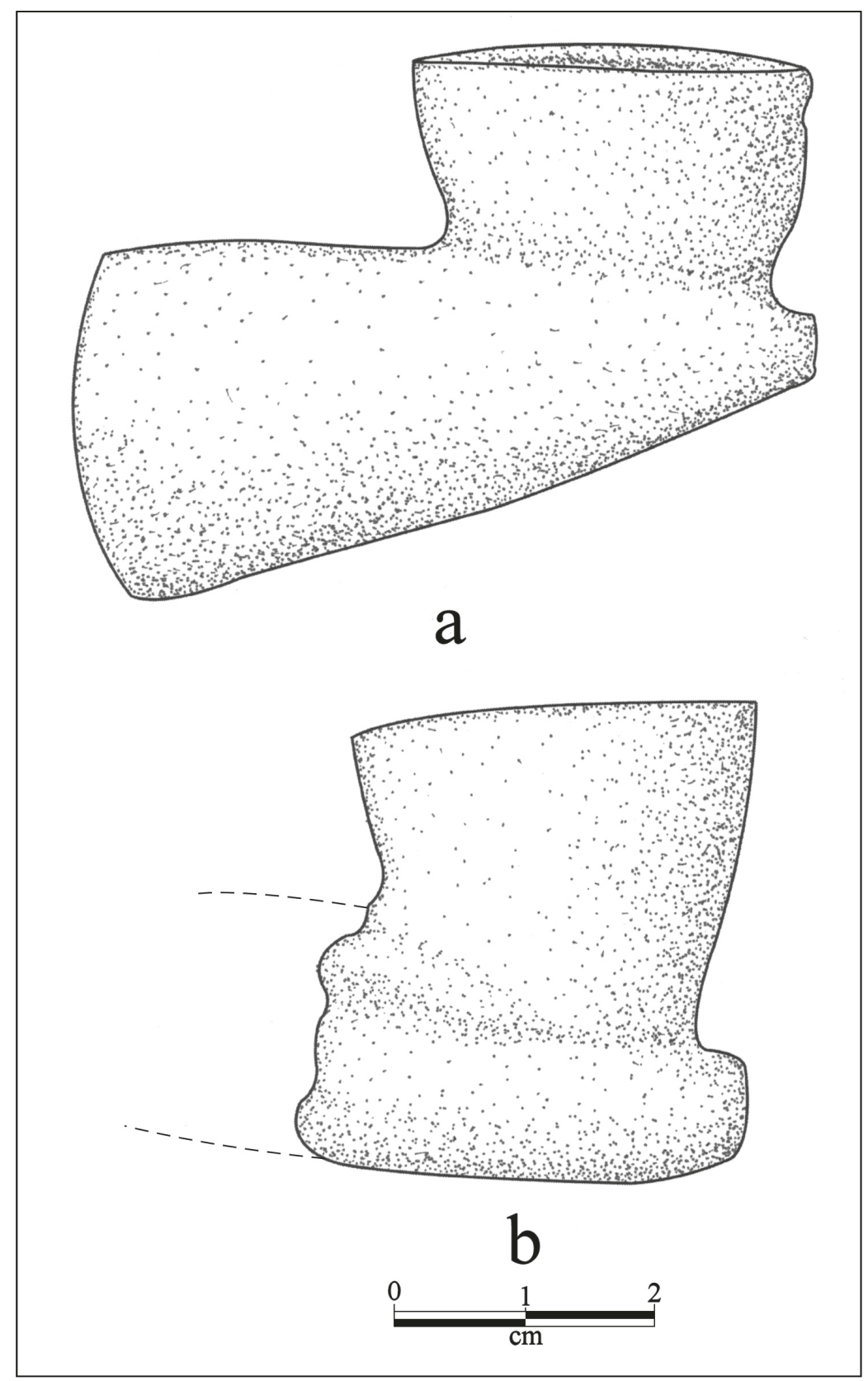

Figure 17. L-shaped elbow pipes from the Musgano site.

\section{Chipped Stone Lithic Artifacts}

Only a small assortment of chipped stone tools were recovered in the excavations at the Musgano site. This includes several Late Archaic and Woodland period dart points made from locally available quartzite and petrified wood (see Clark and Ivey 1974:Figure 14m-t), including Gary, var. Camden, Kent, Williams, and Yarbrough types. These points indicate a limited use of the site well prior to the primary ancestral Caddo occupation.

The chipped stone tools from the Middle Caddo period occupation include two arrow point preforms and eight arrow points. The preforms have contracting stems, and it is likely they are preforms for Perdiz points; they are made from a local brown chert and a non-local gray novaculite. One of the 
eight points has a parallel stem (cf. Alba or Alba-Bonham, see Shafer 1973), and is made from a nonlocal dark brown chert. Three others are unifacially flaked Perdiz points made from brown chert $(n=2)$ and petrified wood, while three others resemble both Bonham and Perdiz points, but have narrow contracting stems with a flat base; these are made from brown chert, black chert, and a dark grayish-brown chert. The last point is a Bonham point with a long blade and substantial barbs; it is made from brown chert. Including the arrow point preforms, 40 percent of the arrow points in the Caddo component at the Musgano site are made from non-local lithic raw materials. These materials have likely source areas in Red River gravels (novaculite and black chert) and Central Texas gravel sources (dark brown and dark grayish-brown chert).

\section{Analysis of the Paleobotanical Remains from the Musgano Site}

\section{Leslie L. Bush}

Eight lots of botanical samples collected during 1973 investigations at the Musgano site (41RK19) were submitted for identification. The relatively large size of the botanical materials and the dearth of associated sediment suggests they were recovered via screening through a standard 1/4-inch mesh.

\section{Ecological setting}

The Musgano site is situated in northern Rusk County, Texas (see Figure 1), on what is now an island in Martin Lake. Mean annual precipitation in Rusk County during the period 1951-1980 was 44.7 inches $(1135 \mathrm{~mm})$. Precipitation is distributed fairly evenly over the year, with a slight peak in late spring. The frost-free season in Rusk County averages 225 days and runs from March 29 through November 9 (NFIC 1987:389-390).

Before the lake was constructed, the site was situated on a ridge between Dry Creek and Martin Creek, which drained into the Sabine River. The site area lies squarely in the Pineywoods vegetation region. During pre-settlement times, shortleaf pine (Pinus echinata) shared dominance in the uplands with oaks (Quercus spp., both red and white groups) and hickories (several species, but frequently Carya texana) (Diggs et al. 2006:88-89). Coves and small streams would have supported mixed hardwood-loblolly pine communities. Lower slopes near the Sabine River and tributaries would have featured flood-tolerant hardwoods such as sweetgum (Liquidambar styraciflua), beech (Fagus grandifolia), holly (Ilex spp.), maple and box elder (Acer spp.), and hop hornbeam (Ostrya virginiana) (Diggs et al. 2006:89-90, 98-100).

\section{Vegetation reconstructions}

Commercial harvesting has resulted in significant changes in Pineywoods vegetation since the midnineteenth century, with plantations of loblolly pine replacing shortleaf and longleaf stands. Nonetheless, modern equivalents exist for most prehistoric plant communities in East Texas (Diggs et al. 2006:87). Pollen studies indicate that use of the modern vegetation zones is appropriate for understanding the plants and attendant animal resources available to people during the first and second millennia. Weakly Bog, situated in the Post Oak Savannah vegetation region southwest of Rusk County, provides some of the best data for vegetation reconstruction in the eastern half of Texas during the last 3,000 years (Bousman 1998). Pollen profiles from this bog indicate oak and later oak-hickory woodlands, suggesting that modern plant communities generally provide good analogs for Texas plant communities during the last 3,000 years. A recent study by Bruce Albert in southwest Upshur County also provides supporting data (Albert 2007). Some fluctuations in rainfall and temperature have taken place, however (Bousman 1998:204). Spikes in grass pollen at approximately 500 B.P. and 1500 B.P. suggest drier conditions during those times (Bousman 1998). 


\section{Methods}

Materials from the Musgano site arrived in the Macrobotanical Analysis laboratory in plastic bags, all but two of which included paper tags in direct contact with the carbonized plant material. Despite this possible contamination by contact with modern plant material, all samples were subject to full radiocarbon protocols in the laboratory to retain whatever suitability they may have for radiocarbon dating. Samples were sorted on freshly cleaned glassware and handled only with latex gloves and metal forceps. Screens, sorting dishes, and scale pans were cleaned between samples. Contact with paper and other plant products was avoided. Only one sample was open at a time in the laboratory. Writing instruments used for data recording of samples were plastic mechanical pencils.

The five samples that included small particles were placed on a clean No. $10(2 \mathrm{~mm})$ mesh to separate charcoal of identifiable size from sediment and charcoal flecks. Soil peds, rocks, and modern rootlets that did not fall through the mesh were removed, weighed, bagged, and labeled. Residue that fell through the mesh was examined under a stereoscopic light microscope to ensure that it contained only wood charcoal and other fragments consistent with those in the larger size fraction. Whole cupules that fell through the mesh were removed and measured, counted, weighed, bagged, and labeled with the other cupules.

Corn parts were categorized and measured according to standard protocols (Bird 1994). When cupules were conjoined into ranks, height measurements were taken on the entire rank and divided by the number of cupules in the rank for better accuracy in evaluating mean cupule height, although variation in height is obscured by this method.

For each sample, 20 wood charcoal fragments were selected for identification at random from those larger than $2 \mathrm{~mm}$. When fewer than 20 fragments were present in a sample, identification was attempted for all. Fragments were snapped to reveal a clean transverse section and examined under a stereoscopic light microscope at 28-180 X magnification. When necessary, tangential or radial sections were examined for ray seriation, presence of spiral thickenings, types and sizes of inter-vessel pitting, and other minute characteristics that can only be seen at the higher magnifications of this range.

Botanical materials were identified to the lowest possible taxonomic level by comparison to materials in the Macrobotanical Analysis comparative collection and through the use of standard reference works (Core et al. 1979; Davis 1993; Hoadley 1990; InsideWood 2004; Martin and Barkley 2000; Musil 1963; Panshin and de Zeeuw 1980; Wheeler 2011). Botanical nomenclature follows the PLANTS Database (USDA, NRCS 2013).

\section{Results and Discussion}

\section{Archaeological versus modern plants}

As shown in Tables 14 and 15, some uncarbonized and semi-carbonized plant parts were present in the samples. The uncarbonized spurge family seed from Lot 145/146 is almost certainly modern seed rain, a phenomenon that is well-documented on archaeological sites (Lopinot and Brussell 1982; Miksicek 1987:231). The semi-carbonized pine parts in Lots 143,145/145 and 62 indicate the possibility of recent fires in the site area. It is therefore possible that some of the fully carbonized pine is similarly recent in origin. 


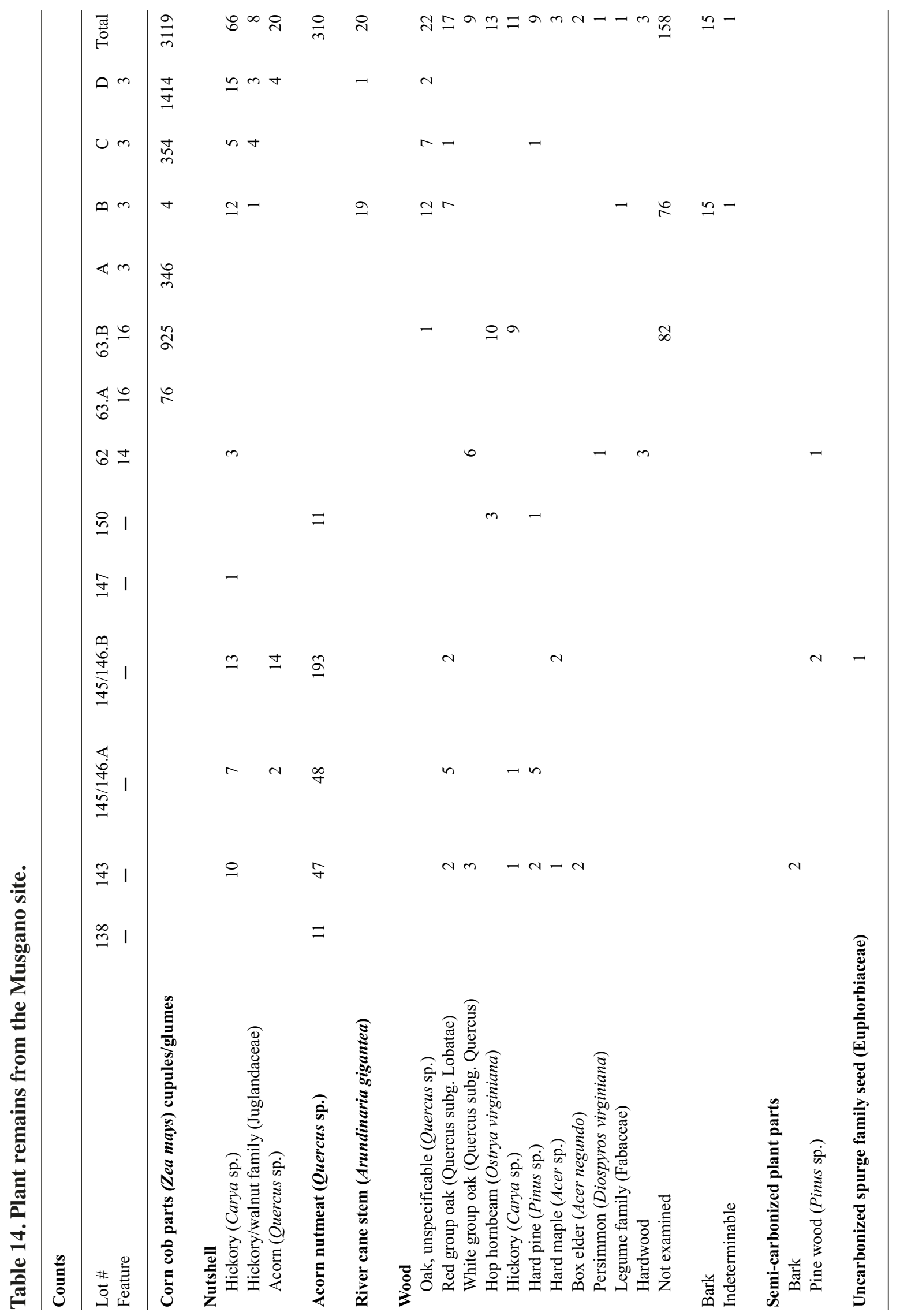




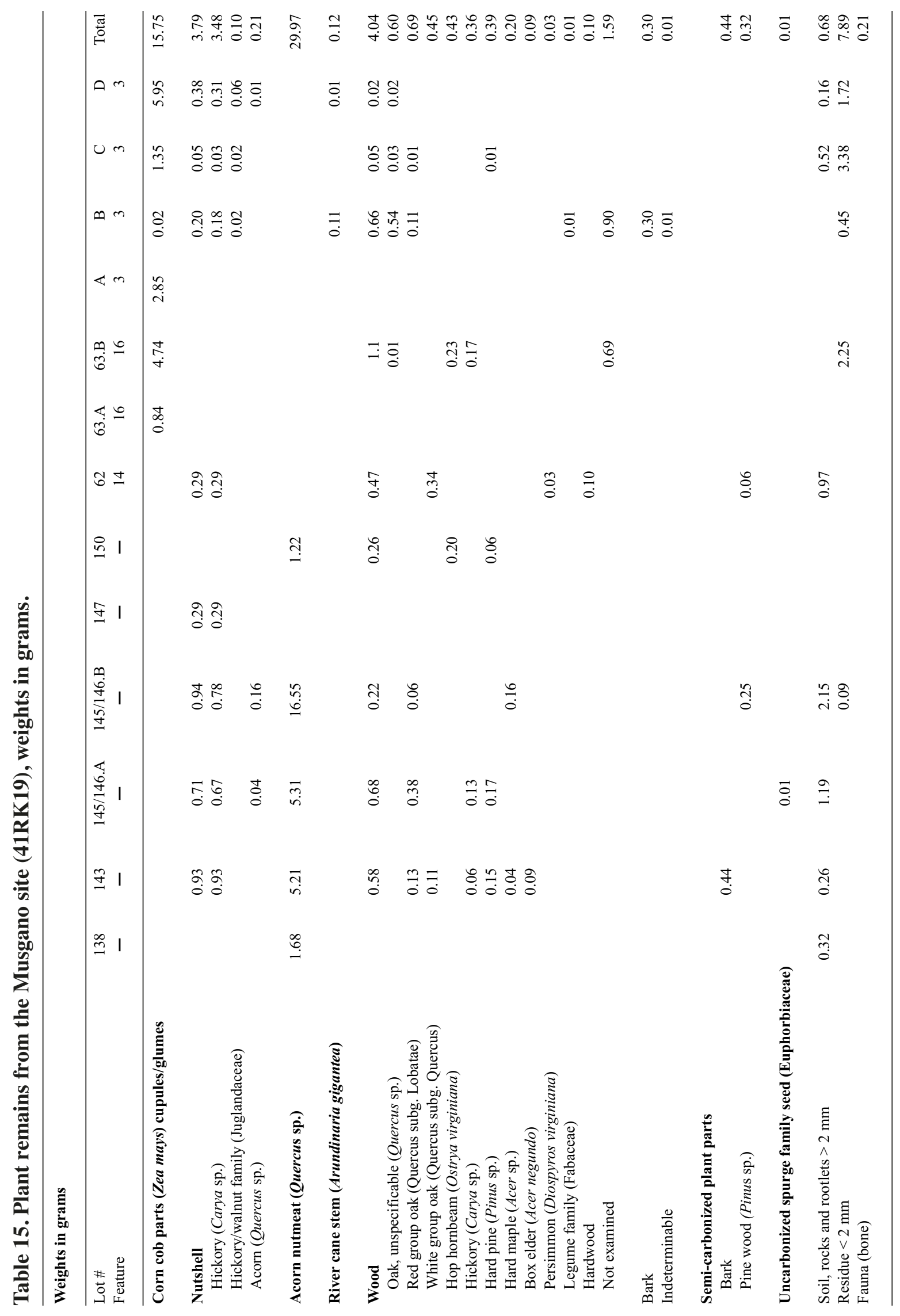




\section{Corn (Zea mays)}

A total of 3119 corn cob parts (cupules, glumes, and fragments) were included in the samples. No whole cobs or complete cob diameters were recovered. Many cupules were conjoined in ranks, however. Most conjoined cupules were in single ranks, but there were three instances of three conjoined ranks and eight instances of two conjoined ranks. Estimates of corn row number from incomplete cob diameters are difficult and subjective, but the six double- and triple-conjoined ranks examined produced estimates of 10 $(\mathrm{n}=1), 14(\mathrm{n}=1)$, and $16(\mathrm{n}=4)$ rows.

Of the 1380 cupules that were sufficiently complete to be measured, 818 were in conjoined ranks, and 562 were loose cupules. Mean cupule width was $4.8 \mathrm{~mm}$, with no difference between conjoined and loose cupules. Cupule height (thickness) was $2.2 \mathrm{~mm}$ overall, but it was $2.3 \mathrm{~mm}$ for conjoined cupules and 2.0 $\mathrm{mm}$ for loose cupules. The difference may reflect distortion during burning. As indicated in Table 16, the cupule measurements from the Musgano site are consistent with those from other Caddo sites, and mean cupule width is identical to that at Oak Hill Village (41RK214), also in Rusk County. A histogram of the cupule widths indicates a unimodal distribution, with no suggestions of two distinct cupule sizes (Figure 18).

Table 16. Mean corn cupule (Zea mays) measurements from selected Caddo sites

Measurements in mm; all cupules carbonized; includes whole cobs, cupules attached in ranks, and loose cupules

\begin{tabular}{lccrl}
\hline & Cupule & $\begin{array}{l}\text { Cupule } \\
\text { thickness } \\
\text { (height) }\end{array}$ & $\begin{array}{l}\text { Number of } \\
\text { cupules } \\
\text { measured }\end{array}$ & Reference \\
\hline Oate & 4.8 & 3.1 & $\sim 10,220$ & Elson et al. 2004 \\
41RK19 & 4.8 & 2.2 & 1,380 & this report \\
41PN175 & 4.9 & 2.3 & 39 & Bush 2013a \\
W. A. Ford (41TT852) & 5.0 & 2.9 & 10 & Bush 2011 \\
Shelby Mound (41CP71) & 5.0 & 2.8 & 52 & Bush 2013b \\
Pine Tree Mound (41HS15) & 5.3 & 2.3 & 106 & Bush 2012 \\
Stallings Ranch (41LR297) & 5.4 & 3.1 & 35 & Bush 2008 \\
Henry M. (41NA60) & 6.1 & 1.9 & 20 & Perttula et al. 2010 \\
Ramos Creek (34MC1030) & 6.5 & 3.1 & 87 & Dowd n.d. \\
Winding Stair (3MN496) & 6.5 & $\mathrm{n} / \mathrm{a}$ & 256 & Williams 2000 \\
Sha'chahdínnih (41MR211)** & 7.2 & 2.8 & 229 & Goldborer 2002 \\
\hline
\end{tabular}

*Mean of measurements given in Table 91. Number of cupules estimated from 108 measurable cobs, row numbers distributed as given in Table 91, assuming 10 measurable cupules per rank.

**Mean of measurements given in Appendix Tables 3A, 3B, 3C, and 3D.

Historical accounts offer more detailed information on Caddo corn than has been available in the archaeological record to date, although much may have changed in the centuries between site occupation and European travels in the area. One of the earliest historical accounts of corn in the Caddo area comes from Fray Francisco Casañas de Jesus Maria, writing to the Viceroy of Mexico in 1691: 


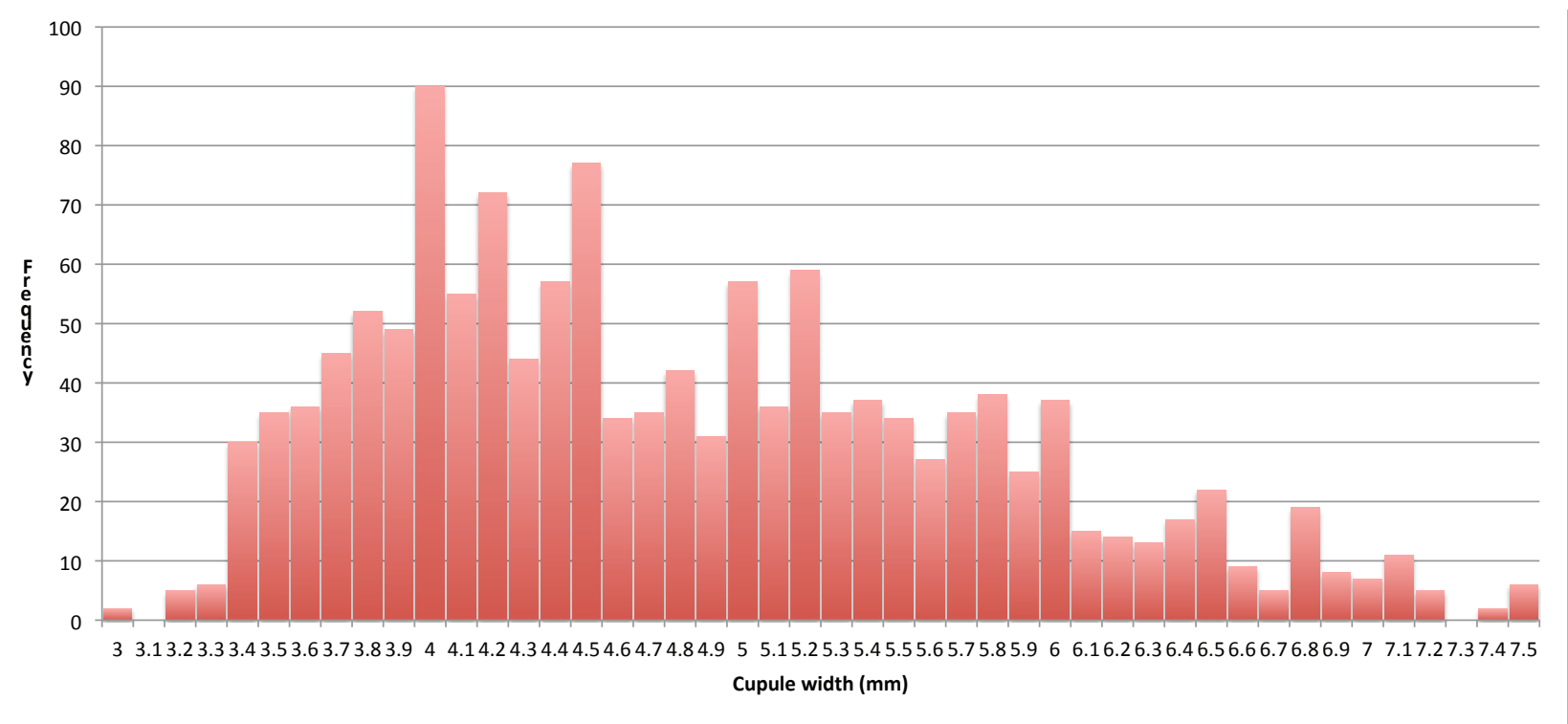

Figure 18. Corn cupule widths from the Musgano site.

Among the seeds which the Indians plant in the proper season, is corn of two kinds, which they plant in abundance. One kind matures in a month and a half and the other in three months (Hatcher 1927:211).

Antoine-Simon Le Page du Pratz lived among Native people in Louisiana and Mississippi in the early eighteenth century, leaning the Natchez language. Although not Caddoan speakers, the Natchez are Mississippian descendants who probably had similar corn traditions. Le Page du Pratz describes six types of corn:

Louisiana produces several kinds of Maiz, namely Flour-maiz, which is white, with a flat and shrivelled surface, and is the softest of all the kinds; Homony corn, which is round, hard, and shining; of this there are four sorts, the white, the yellow, the red, and the blue; the Maiz of these two last colours is more common in the high lands than in the Lower Louisiana. We have besides small corn, or small Maiz, so called because it is smaller than the other kinds. New settlers sow this corn upon their first arrival, in order to have whereon to subsist as soon as possible; for it rises very fast, and ripens in so short a time, that from the same field they may have two crops of it in one year. Besides this, it has the advantage of being more agreeable to the taste than the large kind (Le Page du Pratz 1774:Book III, Chapter I)

\section{Nut resources}

Nutshell was found in five of the eight samples (94 fragments; $3.79 \mathrm{~g}$ ). Most of it was thick-shelled hickory (Carya spp.; n=66), but eight specimens could be identified only as hickory/walnut family (Juglandaceae), and 20 acorn shell fragments (Quercus spp.) were also recovered. Four samples yielded acorn nutmeat. Nutritionally, hickory and acorn nutmeats are not terribly similar, with hickory nuts having twice the fat and a third again as much protein as the same weight of acorns (Table 17). 
Table 17. Proximate analysis of nut resources represented at the Musgano site: values per 100 grams of edible portion (USDA, ARS 2013).

\begin{tabular}{lrr}
\hline & $\begin{array}{r}\text { Hickory (dried) } \\
\text { Carya } \text { spp. }\end{array}$ & $\begin{array}{r}\text { Acorn (dried) } \\
\text { Quercus spp. }\end{array}$ \\
\hline Water $(\mathrm{g})$ & 2.65 & 5.06 \\
Energy (kcal) & 657 & 509 \\
Protein (g) & 12.72 & 8.10 \\
Total lipid (fat) $(\mathrm{g})$ & 64.37 & 31.41 \\
Ash (g) & 2.00 & 1.78 \\
Carbohydrate, by difference $(\mathrm{g})$ & 18.25 & 53.66 \\
\hline
\end{tabular}

\section{Fuel wood}

A total of 249 fragments of wood charcoal weighing $4.04 \mathrm{~g}$ were recovered in the samples. Ninetyone fragments were examined for species identification, of which 88 could be identified to genus or species. Fifty-five percent of the wood charcoal was oak (Quercus spp.; $n=48$ ), with more red group oaks present than white. After oak, hop hornbeam (Ostrya virginiana; $\mathrm{n}=13$ ), hickory (Carya sp.; $\mathrm{n}=11$ ), and pine (Pinus sp.; $\mathrm{n}=9$ ) were the most common woods. Maple, box elder, persimmon, and an unidentifiable legume (e.g., red bud or honeylocust) were also represented.

\section{River cane}

In addition to the corn, nut resources, and fuel wood, one additional plant type was recovered: 20 fragments of river cane (Arundinaria gigantea) were found in Feature 3. Cane has many uses among Native people, including mats, baskets, screens to divide rooms, spear shafts, arrow shafts, pipe stems, blow guns, flutes, and blow tubes used in healing (Moerman 1998:104). Henri Joutel mentions use of cane for torches: "They had lit some dry canes to see better because they do not have knowledge of candle-making nor of burning oil (although they make oil with nuts)" (Foster 1998:235).

\section{Analysis of the Faunal Remains from the Musgano Site (41RK19), A Caddo Site in Rusk County, Texas}

\section{LeeAnna Schniebs}

Archaeological investigations at the Musgano site (41RK19) on Martin Creek in Rusk County, Texas, yielded a total of 951 faunal specimens; 581 (61 percent) fragments are burned, and 222 (23.3 percent) are identifiable. Standard zooarchaeological identification techniques were employed in this analysis, using comparative skeletal collections. Attributes that were examined for each of the bone fragments include taxon, element and portion of that element, symmetry, and burning. This analysis focuses on identifying general preferences of animal exploitation during the time period of ca. A.D. 1350-1450 when the site was occupied. Table 18 summarizes the results of the analysis. 
Table 18. Summary of taxonomic recovery from the Musgano site (41RK19).

\begin{tabular}{|c|c|c|c|c|c|}
\hline Taxon & NISP* & Percent & MNI & Habitat & Burned \\
\hline $\begin{array}{l}\text { Vertebrata } \\
\text { (indeterminate) }\end{array}$ & 166 & 17.5 & - & - & 145 \\
\hline $\begin{array}{l}\text { Box turtle } \\
\text { (Terrapine sp.) }\end{array}$ & 18 & 1.9 & 1 & $\mathrm{~W}, \mathrm{~B}$ & 1 \\
\hline $\begin{array}{l}\text { Indeterminate turtle } \\
\text { (Testudinata) }\end{array}$ & 59 & 6.2 & - & - & 51 \\
\hline Turkey (Meleagris gallopavo) & 2 & 0.2 & 1 & WE & - \\
\hline $\begin{array}{l}\text { Cottontail } \\
\text { (Sylvilagus sp.) }\end{array}$ & 3 & 0.3 & 1 & WE, B & - \\
\hline $\begin{array}{l}\text { Squirrel } \\
\text { (Sciuridae) }\end{array}$ & 2 & 0.2 & 1 & $\mathrm{~W}, \mathrm{~B}$ & 2 \\
\hline White-tailed deer (Odocoileus virginianus) & 138 & 14.5 & 4 & WE & 49 \\
\hline Mammal (small Mammalia) & 7 & 0.7 & - & - & 5 \\
\hline Mammal (large Mammalia) & 556 & 58.5 & - & - & 328 \\
\hline Totals & 951 & 100 & 8 & - & 581 \\
\hline
\end{tabular}

*NISP=number of identified specimens, MNI=minimum number of individuals.

Preferred Habitat (Davis 1978): WE=wooded edges (open meadows, parkland), W=woodlands (deciduous or pine forests), $\mathrm{B}=$ bottomlands (riparian habitats).

Taxonomic composition at the Musgano site is typical of most Caddo habitation sites, comprised of animals that are plentiful in the rich environment of the Pineywoods in East Texas. The collection is dominated by unidentifiable large mammal bone fragments $(n=556)$, which are probably deer remains. These are small fragments from larger elements, and many are abraded and exfoliated. Identifiable remains are comprised mainly of deer $(n=138$, Table 19). Turkey, cottontail, and squirrel are represented by at least two specimens each, while there are many turtle shell fragments $(n=77)$. The presence of these animals indicates the hunting of wetlands, bottomlands, and wooded edges. The indeterminate turtle shell fragments are probably from box turtle or musk/mud turtle rather than pond turtles based on their size: these are small fragments from smaller turtles. 
Table 19. Composition of identified elements in the Musgano site (41RK19) faunal collection.

\begin{tabular}{|c|c|c|c|}
\hline Taxon & Element & NISP & $\begin{array}{l}\text { Total } \\
\text { Taxon }\end{array}$ \\
\hline Box turtle & shell fragment & 18 & 18 \\
\hline Turtle & shell fragment & 59 & 59 \\
\hline \multirow[t]{2}{*}{ Turkey } & ulna fragment & 1 & \\
\hline & rib & 1 & 2 \\
\hline \multirow[t]{3}{*}{ Cottontail } & maxilla & 1 & \\
\hline & tooth & 1 & \\
\hline & phalanx & 1 & 3 \\
\hline \multirow[t]{2}{*}{ Squirrel } & tooth & 1 & \\
\hline & humerus fragment & 1 & 2 \\
\hline \multirow[t]{23}{*}{ Deer } & antler fragment & 5 & \\
\hline & petrous & 1 & \\
\hline & petrous fragment & 3 & \\
\hline & tooth & 6 & \\
\hline & tooth fragment & 34 & \\
\hline & vertebra fragment & 4 & \\
\hline & scapula fragment & 1 & \\
\hline & pelvis fragment & 2 & \\
\hline & humerus fragment & 3 & \\
\hline & radius fragment & 2 & \\
\hline & ulna fragment & 2 & \\
\hline & femur fragment & 2 & \\
\hline & tibia fragment & 11 & \\
\hline & paradigit & 1 & \\
\hline & metatarsal fragment & 2 & \\
\hline & metapodial fragment & 40 & \\
\hline & astragalus & 2 & \\
\hline & astragalus fragment & 4 & \\
\hline & calcaneus & 1 & \\
\hline & calcaneus fragment & 5 & \\
\hline & scaphoid & 1 & \\
\hline & phalanx & 2 & \\
\hline & phalanx fragment & 4 & 138 \\
\hline \multicolumn{3}{|c|}{ Total Identified Elements } & 222 \\
\hline
\end{tabular}

The deer elements recovered suggest that the individuals were butchered at or near the site. There are bones from the entire body, although cranial, vertebral, and pelvic elements are lower in quantity than the limb bones. It is generally thought that non-meat parts of large game are left at the kill location and 
that only those body parts with high meat yield or tool value are transported back to the habitation site, especially as distance increases. The recovery (or lack of recovery) of certain elements can be considered evidence of procurement and/or processing tactics. The Musgano site collection suggests that the entire animal was utilized. Unidentifiable large mammal bones (i.e., likely deer) include long bones and a few tooth socket fragments, also implying the use of the entire animal. The limb bones provide much edible meat as well as providing material used to manufacture tools. Based on the identification of three right tibia fragments, there was a minimum of four deer processed at the site. Tooth wear on upper molars ages two of the animals at time of death: one was at least five to six years, and the second is older than five years old. The third individual is much younger, as the epiphyses are not fused on four leg bones and one vertebra, and one petrous bone is from a very small individual, probably a young deer born in the spring.

Faunal remains were recovered from a block excavation and six post hole features, including four sub-features (Table 20). Ten specimens are identifiable, and 17 fragments are burned.

Table 20. Summary of faunal remains from Musgano site (41RK19) features.

\begin{tabular}{llll}
\hline Feature & Taxon & Element & NISP \\
\hline Feature 139 & box turtle & shell fragment & 1 \\
Feature 142 & large mammal & unidentifiable & 3 \\
Feature 136, 147-145 & deer & astragalus & 1 \\
& deer & tibia fragment & 1 \\
Feature 136, 147-146 & deer & tooth fragment & 3 \\
& deer & metapodial fragment & 1 \\
Feature 136, 147-147 & large mammal & long bone fragment & 4 \\
& large mammal & unidentifiable & 6 \\
Feature 136, 147-148 & large mammal & alveolar fragment & 1 \\
& turtle & shell fragment & \\
& turkey & ulna fragment & 1 \\
\hline
\end{tabular}

Totals

Over half of the collection is burned (see Table 18), suggesting refuse disposal. Those fragments which are small and not burned may be evidence of bone grease processing.

Deer provided the main source of protein for the Caddo occupants at the Musgano site, supplemented by turkey, turtles, rabbit, and squirrel. The small mammal $(n=7)$ and indeterminate vertebrate $(n=166)$ are most likely remains of these animals as well as the possibility of others such as pocket gopher, beaver, opossum, raccoon, skunk, bobcat, and/or rats and mice. The absence of these animals is curious as they can be common in Caddo faunal assemblages and are abundant wildlife in the area. They would have provided additional protein to the diet, and the furs of the medium-sized animals would have been luxurious in the colder seasons. The fat would have provided grease for cooking. Most likely, more deer and other species were actually consumed at the Musgano site. 


\section{Summary and Conclusions}

The Musgano site (41RK19) is an important ancestral Caddo habitation site on Martin Creek in Rusk County in the Sabine River basin in the East Texas Pineywoods. The site was investigated by the Texas Archeological Survey at The University of Texas at Austin (UT) in 1972 and 1973 prior to the construction of Martin Creek Lake by Texas Utilities Services, Inc., and a Caddo house structure, midden deposits, features, and a large ceramic assemblage were documented from a component speculated to date between ca. A.D. 1400-1500. This monograph is a product of the reanalysis of existing excavation and feature records as well as the recovered artifact assemblage that are curated at the Texas Archeological Research Laboratory at The University of Texas at Austin (TARL), since the initial results of the excavations and the recovered artifact assemblage received only the most cursory investigation and analysis.

The Musgano site is located on several knolls across an eastward-projecting alluvial terrace between Martin Creek and Wasson Branch, overlooking a spring-fed slough in the Martin Creek floodplain. The upland ridge was not flooded by Martin Creek Lake, but is currently an island in the central part of the lake. The site is estimated to cover approximately 4 acres, with archaeological deposits averaging about $43 \mathrm{~cm}$ in thickness in A- and E-horizon sediments of the Attoyac series overlying an orange-red B-horizon clay. During the 1972 survey and test excavations, possible midden deposits were identified in one $1 \mathrm{x} 1 \mathrm{~m}$ unit just north of the complex of features, midden deposits, and a house structure area investigated in 1973.

The site was recommended for additional archaeological investigations by UT, and those investigations were carried out in 1973; most of the excavations took place on the southernmost knoll. The excavations on the southern knoll consisted of an area of ca. 12 × 5 m that was stripped with a front end loader as well as the hand excavation of $172 \times 2 \mathrm{~m}$ units $\left(68 \mathrm{~m}^{2}\right)$; most of these units were in a contiguous block just north and east of the bladed area. Two $2 \times 2 \mathrm{~m}$ units were excavated on both the northern and eastern knolls, and various backhoe trenches were excavated on and in the vicinity of the northern and southern knolls.

Archaeological deposits in the block area consisted of a plow zone (ca. 0-10 cm bs), followed by a dark brown sandy loam midden (ca. 10-35 cm bs) with pit and post hole features (or a brown sandy loam outside of the main midden deposits) originating from the base of this deposit, and a light tan loam (ca. $35-60 \mathrm{~cm}$ bs). These sediment zones rested on a red clayey loam subsoil.

Numerous cultural features were identified in the block excavations and stripped area, including 90 post holes, many associated with a circular Caddo house, and several post holes that may be part of a possible granary. This feature is marked by a roughly circular pattern of posts about $3.5 \mathrm{~m}$ in diameter, a size consistent with other granaries identified and documented in East Texas Caddo sites. Other post holes occur in several areas outside of the structure, in outdoor work and midden areas, and these likely represent elevated work platforms, racks, and screens.

The Caddo house is circular, ca. $6 \mathrm{~m}$ in diameter. One $1.5 \mathrm{~m}$ gap in the structure wall post holes suggest that the entrance to the house was on its southwest side, but because a portion of the house area was not excavated, this is not conclusive. Within the house is a ca. $40 \mathrm{~cm}$ diameter burned area with charcoal and ash, $13 \mathrm{~cm}$ in depth, that is the central hearth.

The main midden deposits at the Musgano site occur immediately outside portions of the east, north, and south walls of the house. It is about $9 \mathrm{~m}$ north-south and ca. $7.75 \mathrm{~m}$ east-west. A second midden deposit in the far western part of the block suggests there may be a second house compound on the western part of the knoll (outside of the stripped area). 
Other features include pits $(n=28)$ of various sizes and contents; 14 of the pits are inside the house; five pits are in the midden along the east side of the house; and the others are a few $\mathrm{m}$ away from the west side of the house. The larger pits are probably storage pits that eventually were disused and trash was thrown into them for disposal. The smaller pits $(n=13)$ had lesser quantities of charcoal and other trash than the larger pits, but their functions are not known.

The radiocarbon dating of six samples of organic remains (three corn cupule samples, cane stem, and hickory and oak nutshells and nutmeat) from the archaeological deposits at the Musgano site indicate that the primary Caddo occupation took place between A.D. 1250-1440, during the Middle Caddo period. The principal peaks in probability density occur at ca. A.D. 1260-1280 and A.D. 1400-1440, and the calibrated median ages range from A.D. 1278-1431. The calibrated age ranges with the highest probabilities at 2 sigma are: A.D. 1244-1302, A.D. 1344-1395, A.D. 1394-1443, A.D. 1405-1455, and A.D. 1389-1437. Four of these age ranges fall from A.D. 1344-1455. It is likely that this period represents the time of the principal Caddo occupation of the Musgano site during the latter years of the Middle Caddo period in the mid-Sabine River basin.

The archaeological investigations at the Musgano site resulted in the collection of a large assemblage of decorated utility ware and fine ware rim and body sherds from habitation deposits on three different knolls. The stylistic character of these sherds is useful in assessing the age of the Caddo occupation at the site, and in outlining the historical relationships evidenced in the decorative elements and motifs that speak of cultural transmission and stylistic change and continuity in the decoration of Caddo vessels in the mid-Sabine River basin. As best as can be determined from the decorated sherd assemblage and clay pipes from the Musgano site, the principal ancestral Caddo domestic settlement predates ca. A.D. 1450, possibly dating to between ca. A.D. 1350-1450. The engraved fine wares, and the incised-punctated variant of Washington Square Paneled sherds at the Musgano site, are not stylistically similar to the postA.D. 1450 fine wares documented from the Pine Tree Mound community (see Fields and Gadus 2012) a few miles to the north on another tributary of the Sabine River. Instead they are more like ceramic assemblages on Middle Caddo period (ca. A.D. 1200-1450) sites in the mid-Sabine and Angelina River basins (cf. Gadus et al. 2006; Hart 1982; Perttula and Nelson 2013; Walters 2008, 2010), and it is likely that various Caddo communities in these areas had close social and cultural ties and established networks of contact and cultural transmission of ideas and practices.

The ceramic sherd assemblage is predominantly from grog-tempered vessels (88.7 percent); the remainder are from bone-tempered vessels. There are 32 rim sherds from plain wares in the Musgano ceramic assemblage. This represents 15.4 percent of all the rim sherds in the collection, indicating that plain ware vessels (jars and bowls, primarily) are well represented at the site. This compares to 23 fine ware rim sherds and 153 utility ware rim sherds.

More than 91 percent of the decorated sherds from the Musgano site are from utility ware vessels $(n=1913)$; fine wares (sherds with engraved and red-slipped decorative elements) comprise only 8.8 percent of the decorated sherd assemblage. Among the decorated rim sherds, 87 percent are from utility ware vessels, particularly vessels with punctated (primarily rows of tool punctations), incised-punctated (from Maydelle Incised jars), incised (most from Maydelle Incised vessels), brushed (probably from Bullard Brushed jars), and brushed-punctated (also probably from Bullard Brushed jars) decorative elements. Other utility wares include sherds from Pease Brushed-Incised vessels and Killough Pinched jar sherds. Several of the incised-punctated sherds from the Musgano site are from Washington Square Paneled vessels. The rim panels of these carinated bowls have horizontal interlocking incised scrolls with upper, lower, and vertical incised bands filled with tool punctates. This particular decorative style on the rims from these vessels has a considerable distribution on Middle Caddo (ca. 
A.D. 1200-1450) period sites in the mid-Sabine River basin and tributaries as well as contemporaneous Caddo sites in the Angelina River basin.

Among the fine ware sherds, the rims from engraved carinated bowls and bowls in the Musgano assemblage feature circular and curvilinear elements, sets of diagonal lines, and rims with horizontal lines and various associated elements. These include curvilinear and diagonal lines, zig-zag lines, excised punctations, hatched pendant triangles, cross-hatched zones (possibly triangular elements), and hatched oval-shaped elements. The rims with horizontal engraved lines and associated elements comprise 72.9 percent of the engraved rims from carinated bowls and bowls. None of the rims have scroll elements, which feature so prominently in post-ca. A.D. 1450 assemblages in the mid-Sabine River basin (e.g., Fields and Gadus 2012). Furthermore, none of the engraved rims from the Musgano site can be identified with a currently defined fine ware type in the current East Texas ceramic typology, which is a common situation for Middle Caddo period fine wares in this part of East Texas because of the stylistic diversity that is characteristic of these ca. A.D. 1200-1450 ceramic assemblages. The decorative elements on the engraved carinated bowl and bowl sherds from the Musgano site are as diverse as the recognizable elements on the rims; none of the sherds are part of a scroll motif. The more recognizable and distinctive elements include circles and hatched circles, narrow hatched and cross-hatched zones and cross-hatched triangles, curvilinear hatched and cross-hatched zones as well as hatched pendant triangles, horizontal engraved lines with hatched and cross-hatched pendant triangles, and sets and arcs of curvilinear lines. Many of the same engraved elements are present in the nearby and generally contemporaneous Oak Hill Village (41RK214) ceramic assemblage (Rogers and Perttula 2004:217-222) as well as other mid-Sabine River basin sites. These include closely-spaced curvilinear lines; hatched and cross-hatched triangle elements; narrow hatched and cross-hatched zones or ladders (the most common engraved decorative element at the Oak Hill Village); and circle elements and concentric circles with pendant triangles.

Engraved sherds from bottles comprise almost 24 percent of the engraved fine wares from the Musgano site. There is one engraved bottle rim sherd from a Hickory Engraved bottle that has a series of horizontal lines encircling the neck. The decorative elements on the bottle bodies are diverse, with circles, hatched and cross-hatched ovals and narrow panels and zones, as well as possible canebrake rattlesnake elements from Nacogdoches Engraved vessels. Engraved canebrake rattlesnake motifs on bottles have been found in ceramic assemblages in at least 17 Middle and Late Caddo period sites in the Big and Little Cypress Creek, mid-Sabine, Red River, and Angelina River basins in East Texas.

Ceramic pipe sherds are relatively abundant in the archaeological deposits at the Musgano site. They include sherds from long-stemmed Red River pipes, probably var. Haley (Hoffman 1967), bowl and stem sherds from distinctive L-shaped elbow pipes, and portions of two squat L-shaped elbow pipes. The Lshaped elbow pipes have been found at a number of other East Texas (i.e., Sabine, Neches, and Angelina River basins) Caddo sites with Middle Caddo period occupations.

The chipped stone tools from the Middle Caddo period occupation include two arrow point preforms and eight arrow points. The preforms have contracting stems, and it is likely they are preforms for Perdiz points. One of the eight points has a parallel stem (cf. Alba or Alba-Bonham), while three others are unifacially flaked Perdiz points. Three others resemble both Bonham and Perdiz points, but have narrow contracting stems with a flat base. The last point is a Bonham point with a long blade and substantial barbs. Including the arrow point preforms, 40 percent of the arrow points in the Caddo component at the Musgano site are made from non-local lithic raw materials. These materials have likely source areas in Red River gravels (novaculite and black chert) and Central Texas gravel sources (dark brown and dark grayish-brown chert). 
Corn cob parts (cupules, glumes, and fragments) are abundant in the charred plant remains from the Musgano site. Mean cupule width is $4.8 \mathrm{~mm}$, and cupule height (thickness) is $2.2 \mathrm{~mm}$ overall. The cupule measurements from the Musgano site are consistent with those from other East Texas Caddo sites. Other charred plant foods include thick-shelled hickory and acorn. Wood charcoal is dominated by oak, with lesser amounts of hop hornbeam, hickory, and pine. Fragments of river cane were also recovered from a feature; cane may have been used for mats, baskets, screens, arrow shafts, etc.

Animal bones were well-preserved in the archaeological deposits from the Musgano site. The collection is dominated by unidentifiable large mammal bone fragments, which are probably deer remains. Identifiable remains are comprised mainly of deer, and turkey, cottontail, and squirrel are represented by at least two specimens each; there are many turtle shell fragments (probably box or musk/mud turtles). The deer elements recovered suggest that individuals (adults and young individuals) were butchered at or near the site. The presence of these animals in trash deposits and features at the site indicates the hunting of wetlands, bottomlands, and wooded edges.

In summary, the Musgano site is a well-preserved 14th to mid-15th century ancestral Caddo habitation site (with one to several inhabited house structures) in the Martin Creek valley in the mid-Sabine River basin. The Caddo peoples that lived there were apparently farmers that interacted widely with neighboring communities in the mid-Sabine and upper Neches River basins in East Texas, as surmised through similarities in decorative and technological styles of their locally produced ceramic wares. The Musgano site is still preserved on an island in Martin Creek Lake, and depending upon its current preservation condition, further excavations at the site are well warranted to better understand its spatial and functional character during the Middle Caddo period occupation there. 


\section{References Cited}

Albert, B. M.

2007 Climate, Fire, and Land-use History in the Oak-Pine-Hickory Forests of Northeast Texas during the past 3500 Years. Castanea 72(2):82-91.

Bird, R. McK.

1994 Manual for the Measurement of Maize Cobs. In Corn and Culture in the Prehistoric New World, edited by S. Johannessen and C. A. Hastorf, pp. 5-22. Westview Press, Boulder, Colorado.

Bousman, C. B.

1998 Paleoenvironmental Change in Central Texas: The Palynological Evidence. Plains Anthropologist 43(164):201-219.

Brown, J. A.

1996 The Spiro Ceremonial Center: The Archaeology of Arkansas Valley Caddoan Culture in Eastern Oklahoma. 2 Vols. Memoirs No. 29. Museum of Anthropology, University of Michigan, Ann Arbor.

Bush, L. L.

2008 Macrobotanical Remains from the 2005 and 2006 Texas Archeological Society Field Schools at the Gene and Ruth Ann Stallings Site (41LR297). 30 pp. Manuscript submitted to the Texas Archeological Society, San Antonio, Texas, June 28, 2008.

2011 Plant Remains from the Mount Pleasant Bypass Project: Three Caddo Hamlets on the Post Oak Savannah. Manuscript submitted to Prewitt and Associates, Inc., Austin, Texas. April 11, 2011.

2012 Macrobotanical Remains. In Archeology of the Nadaco Caddo: The View from the Pine Tree Mound Site (41HS15), Harrison County, Texas, edited by R. C. Fields and E. F. Gadus, pp. 728-772. 2 Vols. Reports of Investigations No. 164. Prewitt and Associates, Inc., Austin.

2013a Plant Remains from Site 41PN175, Panola County, Texas. Manuscript submitted to Geo-Marine, Inc., Plano, Texas. July 26, 2013.

2013b Plant Remains from Shelby Mound (41CP71), Camp County, Texas. Journal of Northeast Texas Archaeology 46:45-55.

Clark, J. W and J. E. Ivey

1974 Archaeological and Historical Investigations at Martin Lake, Rusk and Panola Counties, Texas. Research Report 32. Texas Archeological Survey, Austin.

Core, H. A., W. A. Cote, and A. C. Day

1979 Wood Structure and Identification. 2nd Edition. Syracuse University Press, Syracuse, New York.

Davis, L. W.

1993 Weed Seeds of the Great Plains: A Handbook for Identification. University Press of Kansas, Lawrence.

Davis, W. B.

1978 The Mammals of Texas. Bulletin No. 41, revised. Texas Parks and Wildlife Department, Austin. 
Diggs Jr., G. M., B. L. Lipscomb, M. D. Reed, and R. J. O’Kennon

2006 Illustrated Flora of East Texas, Volume One: Introduction, Pteridophytes, Gymnosperms, and Monocotyledons Sida, Botanical Miscellany, No. 26. Botanical Research Institute of Texas, Fort Worth.

Dockall, J. E. and R. C. Fields

2011 National Register Testing of Three Sites in the Sabine Mine's South Hallsville No. 1 Mine-Rusk Permit, Rusk County, Texas. Reports of Investigations No. 162. Prewitt and Associates, Inc., Austin.

Dockall, J., S. Katauskas, and R. Fields

2008 National Register Testing of Four Sites in the Sabine Mine's Area M, Harrison County, Texas. Reports of Investigations No. 157. Prewitt and Associates, Inc., Austin.

Dowd, E. L.

n.d. Mountain Fork Archaeology: A View from the Ramos Creek Site (34MC1030). Sam Noble Oklahoma Museum of Natural History, Norman.

Elson, K. M., C. Smith, and T. K. Perttula

2004 Additional Maize Studies. In The Oak Hill Village Site (41RK214), Rusk County, Texas, by R. Rogers and T. K. Perttula, pp. 323-335. Document No. 030083. PBS\&J, Austin.

Ferguson, J. R. and M. D. Glascock

2012 Instrumental Neutron Activation Analysis of Ceramic and Clay Samples from the Pine Tree Mound Site (41HS15), Harrison County, Texas. In Archeology of the Nadaco Caddo: The View from the Pine Tree Mound Site (41HS15), Harrison County, Texas, edited by R. C. Fields and E. F. Gadus, pp. 773-796. 2 Vols. Reports of Investigations No. 164. Prewitt and Associates, Inc., Austin.

Fields, R. C. and E. F. Gadus (editors)

2012 Archeology of the Nadaco Caddo: The View from the Pine Tree Mound Site (41HS15), Harrison County, Texas. 2 Vols. Reports of Investigations No. 164. Prewitt and Associates, Inc., Austin.

Foster, W. C. (editor)

1998 The La Salle Expedition to Texas: The Journal of Henri Joutel, 1684-1687. Texas State Historical Association, Austin.

Gadus, E. F.

2013 Twisted Serpents and Fierce Birds: Structural Variation in Caddo Engraved Ceramic Bottle Motifs. Bulletin of the Texas Archeological Society 84:213-245.

Gadus, E. F., R. C. Fields, J. K. McWilliams, J. Dockall, and M. C. Wilder

2006 National Register Testing of Seven Prehistoric Sites in the Sabine Mine's Area Q, Harrison County, Texas. Reports of Investigations No. 147. Prewitt and Associates, Inc., Austin.

Goldborer, S. E.

2002 Macrobotanical Evidence of Subsistence at Timber Hill. In Finding Sha'chahdinnih (Timber Hill): The Last Village of the Kadohadacho in the Caddo Homeland, by M. L. Parsons, J. E. Bruseth, J. Bagur, S. E. Goldborer, and C. McCrocklin, pp. 81-86. Archeological Reports Series No. 3. Texas Historical Commission, Austin. 
Griffith, K.

2001 Soil Survey of Rusk County, Texas. United States Department of Agriculture, Natural Resources Conservation Service, in cooperation with the Texas Agricultural Experiment Station and Texas State Soil and Water Conservation Board.

Hart, J. P.

1982 An Analysis of the Aboriginal Ceramics from the Washington Square Mound Site, Nacogdoches County, Texas. Master's thesis, Department of Anthropology, Northeast Louisiana University, Monroe.

2014 An Analysis of the Aboriginal Ceramics from the Washington Square Mound Site, Nacogdoches County, Texas. Stephen F. Austin State University Press, Nacogdoches.

Hatcher, M. A.

1927 Descriptions of the Tejas or Asinai Indians, 1691-1722, Part I (Casañas de Jesus Maria). Southwestern Historical Quarterly 30:206-218.

Heartfield, Price, and Greene, Inc.

1988 Data Recovery at 41HS74, Harrison County, Texas. Heartfield, Price, and Greene, Inc., Monroe.

Hoadley, R. B.

1990 Identifying Wood: Accurate Results with Simple Tools. The Taunton Press, Newtown, Connecticut.

Hoffman, M. P.

1967 Ceramic Pipe Style Chronology along the Red River Drainage in Southwestern Arkansas. The Arkansas Archeologist 8(1):4-14.

InsideWood

2004-onwards Published on the Internet. http://insidewood.lib.ncsu.edu/search.

Le Page du Pratz, Antoine-Simon

1774 History of Louisiana or of the Western Parts of Virginia and Carolina: Containing a Description of the Countries that lie on both Sides of the River Missisippi:With an Account of the Settlements, Inhabitants, Soil, Climate and Products. Edited and published by J. S. W. Harmanson with an introduction by S. C. Arthur. Text online at http://www.obrienbooks.com/th.html Accessed 6/25/2005.

Lopinot, N. H. and D. E. Brussell

1982 Assessing Uncarbonized Seeds from Open-air Sites in Mesic Environments: An Example from Southern Illinois. Journal of Archaeological Science 9:95-108.

Martin, A. C. and W. D. Barkley

2000 Seed Identification Manual. The Blackburn Press, Caldwell, New Jersey.

McDonald, A. J.

1972 An Archeological Survey of the Martin Lake Area, Rusk and Panola Counties, Texas. Research Report No. 14. Texas Archeological Salvage Project, The University of Texas at Austin.

Miksicek, C. H.

1987 Formation Processes of the Archaeobotanical Record. In Advances in Archaeological Method and Theory, Vol. 10, edited by M. B. Schiffer, pp. 211-247. Academic Press, Inc., New York. 
Moerman, D. E.

1998 Native American Ethnobotany. Timber Press, Portland, Oregon.

Musil, A. F.

1963 Identification of Crop and Weed Seeds Agriculture Handbook No. 219. U.S. Department of Agriculture, Washington, D.C.

Newell, H. P and A. D. Krieger

1949 The George C. Davis Site, Cherokee County, Texas. Memoir No. 5. Society for American Archaeology, Menasha, Wisconsin.

NFIC (Natural Fibers Information Center)

1987 The Climates of Texas Counties. Natural Fibers Information Center, The University of Texas at Austin, in cooperation with the Office of the State Climatologist, Texas A\&M University, College Station.

Panshin, A. J. and C. de Zeeuw

1980 Textbook of Wood Technology: Structure, Identification, Properties, and Uses of the Commercial Woods of the United States and Canada. $4^{\text {th }}$ Edition. McGraw-Hill Book Company, New York.

Perttula, T. K.

2001 Ceramic Analysis. In NRHP Eligibility Testing (41RK107, 41RK240, 41RK242, 41RK243, 41RK276, and 41RK286) and Additional Testing (41RK243) Investigations within the Oak Hill DIII Mine, Permit No. 46, Rusk County, Texas, by D. L. Sherman, Document No. 000237. PBS\&J, Austin.

2011 The Ceramic Artifacts from the Lang Pasture Site (41AN38) and the Place of the Site within an Upper Neches River Basin Caddo Ceramic Tradition. In Archeological Investigations at the Lang Pasture Site (41AN38) in the Upper Neches River Basin of East Texas, assembled and edited by T. K. Perttula, D. B. Kelley, and R. A. Ricklis, pp. 145-320. Archeological Studies Program Report No. 129. Texas Department of Transportation, Environmental Affairs Division, Austin.

2013 Caddo Ceramics in East Texas. Bulletin of the Texas Archeological Society 84:181-212.

Perttula, T. K. (editor)

2008 Lake Naconiche Archeology, Nacogdoches County, Texas: Results of the Data Recovery Excavations at Five Prehistoric Archeological Sites. 2 Vols. Report of Investigations No. 60. Archeological \& Environmental Consultants, LLC, Austin.

Perttula, T. K. and B. Nelson

2003 The Nawi haia ina Site (41RK170): Archeological Investigations in the City of Henderson's Southside Wastewater Treatment Plant, Rusk County, Texas. Report of Investigations No. 51. Archeological \& Environmental Consultants, LLC, Austin.

2013 Two Middle Caddo Period Habitation Sites and Cemeteries in the Sabine River Basin, Gregg County, Texas. Special Publication No. 27. Friends of Northeast Texas Archaeology, Pittsburg and Austin.

2014 The Millsey Williamson (41RK3), Bead Burial, and L. N. Morwell Farm Sites on Martin Creek: Historic Caddo Settlements along Trammels Trace, Rusk County, Texas. Journal of Northeast Texas Archaeology 44:23-46. 
Perttula, T. K. and R. Z. Selden, Jr.

2011 East Texas Radiocarbon Database. Electronic resource, http://counciloftexasarcheologists. org/?page_id=27, July 1, 2013.

Perttula, T. K., L. L. Bush, L. Schniebs, T. Middlebrook, and P. S. Marceaux

2010 An Early Historic Farmstead at the Henry M. Site (41NA60) in Nacogdoches County, Texas. Stephen F. Austin State University Press, Nacogdoches, Texas.

Perttula, T. K., R. Z. Selden, Jr., and B. Nelson

2014a Archaeological Investigations at the Wade (GC-38) and Estes (GC-49) Sites in the Sabine River Basin, Gregg County, Texas. Journal of Northeast Texas Archaeology 45:39-61.

2014b A Catalog of Selected Caddo Ceramic Vessels in the Buddy Jones Collection at the Gregg County Historical Museum. Special Publication No. 30. Friends of Northeast Texas Archaeology, Pittsburg and Austin.

Perttula, T. K., M. Walters, and B. Nelson

2012 Archeological Investigations at the Pace McDonald Site (41AN51): A Middle Caddo Mound Center in the Neches River Basin in East Texas. Special Publication No. 21. Friends of Northeast Texas Archaeology, Pittsburg and Austin.

Perttula, T. K., M. Walters, S. Marceaux, and B. Nelson

2009 Caddo Pottery Vessels and Pipes from Sites in the Middle and Upper Sabine and Upper Neches River Basins, Smith and Wood Counties, Texas. Special Publication No. 7. Friends of Northeast Texas Archaeology, Pittsburg and Austin.

Perttula, T. K., M. Walters, R. Cast, B. Gonzalez, and B. Nelson

2007 Documentation of Funerary Offerings from a Prehistoric Caddo Burial at Site 41WD244, Wood County, Texas. Caddo Nation of Oklahoma and Archeological \& Environmental Consultants, LLC, Binger, Oklahoma and Austin, Texas.

Perttula, T. K., M. Walters, B. Nelson, B. Gonzalez, and R. Cast, with a contribution by R. G. Franciscus

2010 Documentation of Associated and Unassociated Caddo Funerary Objects in the Stephen F. Austin State University Collections, Nacogdoches, Texas. Stephen F. Austin State University Press, Nacogdoches.

Perttula, T. K. and K. Wright

2014 An Engraved Caddo Vessel from the Quitman Area, Wood County, Texas. Journal of Northeast Texas Archaeology 46:69-71.

Rice, P. M.

1987 Pottery Analysis: A Sourcebook. University of Chicago Press, Chicago.

Rogers, R. and T. K. Perttula

2004 The Oak Hill Village (41RK214), Rusk County, Texas. Document No. 030083. PBS\&J, Austin.

Schultz, T. C.

2010 Architectural Variability in the Caddo Area of Eastern Texas. Special Publication No. 16. Friends of Northeast Texas Archaeology, Pittsburg and Austin. 
Selden, R. Z., Jr.

2013 Consilience: Radiocarbon, Instrumental Neutron Activation Analysis and Litigation in the Ancestral Caddo Region. Ph.D. dissertation, Department of Anthropology, Texas A\&M University, College Station.

2014 Instrumental Neutron Activation Analysis in the Ancestral Caddo Territory. Caddo Archeology Journal 24:75-86.

Selden, R. Z., Jr. and T. K. Perttula

2013 Radiocarbon Trends and the East Texas Caddo Tradition (ca. A.D. 800-1680). Southeastern Archaeology 32(1):85-96.

Shafer, H. J.

1973 Lithic Technology at the George C. Davis Site, Cherokee County, Texas. Ph.D. dissertation, Department of Anthropology, The University of Texas at Austin.

Stokes, J. and J. Woodring

1981 Native-Made Artifacts of Clay. In Archeological Investigations at the George C. Davis Site, Cherokee County, Texas: Summers of 1979 and 1980, edited by D. A. Story, pp. 135-238. Occasional Paper No. 1. Texas Archeological Research Laboratory, The University of Texas at Austin.

Story, D. A.

2000 Introduction. In The George C. Davis Site, Cherokee County, Texas, by H. P. Newell and A. D. Krieger, pp. 1-31.2nd Edition. Society for American Archaeology, Washington, D.C.

Suhm, D. A. and E. B. Jelks (editor)

1962 Handbook of Texas Archeology: Type Descriptions. Special Publication No. 1, Texas Archeological Society, and Bulletin No. 4, Texas Memorial Museum, Austin.

USDA, ARS (United States Department of Agriculture, Agricultural Research Service)

2013 USDA National Nutrient Database for Standard Reference. Release 26. http://www.ars.usda.gov/ba/ bhnrc/ndl. Accessed 12/5/2013.

USDA, NRCS (United States Department of Agriculture, Natural Resources Conservation Service)

2013 The PLANTS Database. http://plants.usda.gov. National Plant Data Team, Greensboro, NC 274014901 USA. Accessed 12/5/13.

Walters, M., with contributions from L. G. Cecil, L. S. Cummings, J. P. Dering, J. R. Ferguson, M. D. Glascock, T. K. Perttula, L. Schniebs, H. J. Shafer, J. Todd, and C. P. Walker

2008 Life on Jackson Creek, Smith County, Texas: Archeological Investigations of a 14th Century Caddo Domicile at the Leaning Rock Site (41SM325). Caddo Archeology Journal 17:1-114.

Walters, M., with contributions by T. Middlebrook and T. K. Perttula

2010 Redwine or Pie-Crust Mode Forms in East Texas Caddo Ceramics and comparisons with SprocketRims of Southwest Arkansas. Caddo Archeology Journal 20:77-128.

Walters, M., P. Haskins, D. H. Jurney, S. E. Goldborer, and T. K. Perttula

1998 Archaeological Investigations at the Redwine Site (41SM193), Smith County, Texas. Journal of Northeast Texas Archaeology 11:1-38. 
Wheeler, E. A.

2011 InsideWood - A Web Resource for Hardwood Anatomy. IAWA Journal 32(2):199-211.

Williams, M. L.

2000 Ethnobotanical Analysis (Winding Stair and Bug Spot). In Forest Farmsteads: A Millennium of Human Occupation at Winding Stair in the Ouachita Mountains, edited by A. M. Early, pp. 111122. Research Series 57. Arkansas Archeological Survey, Fayetteville. 
